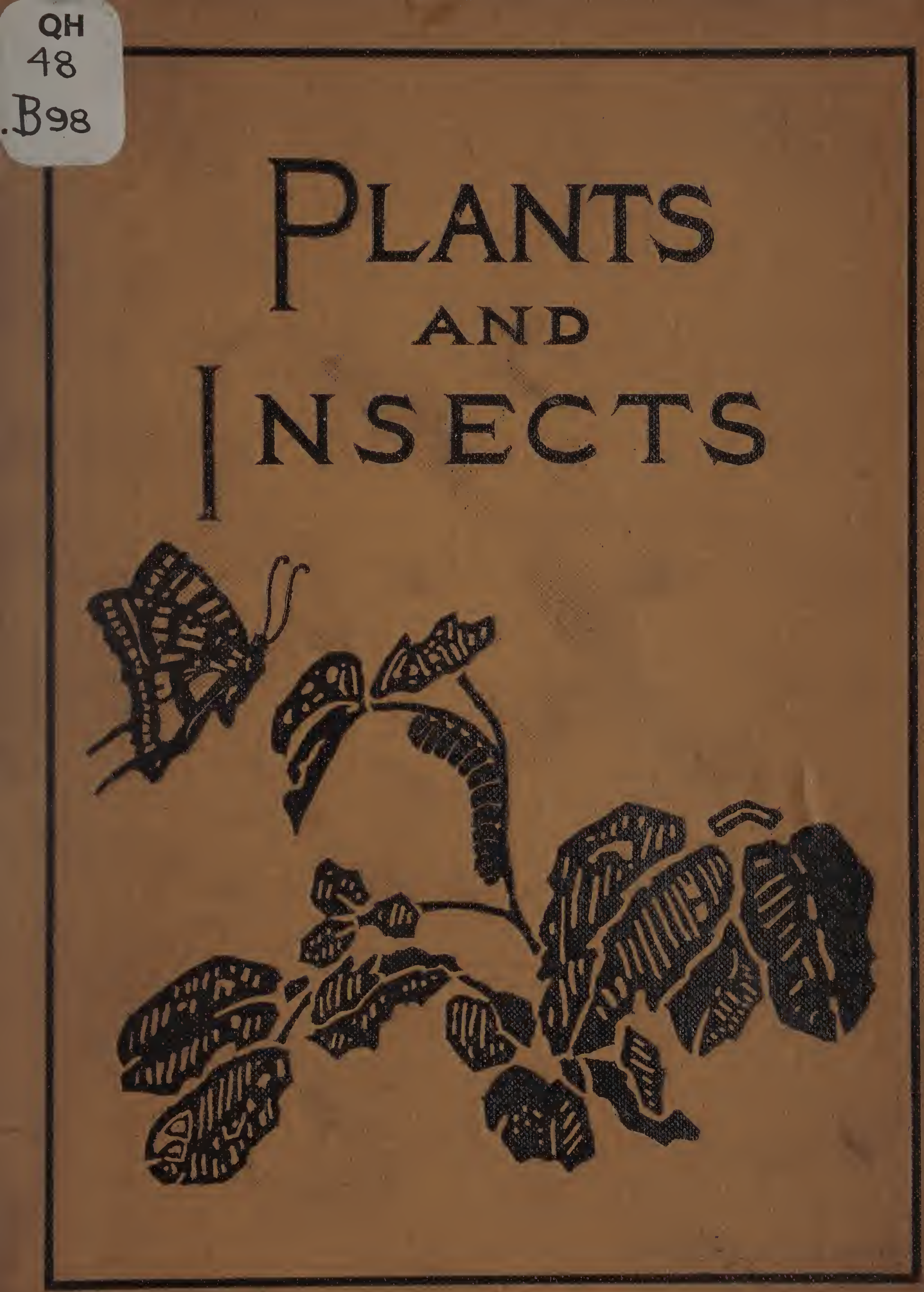



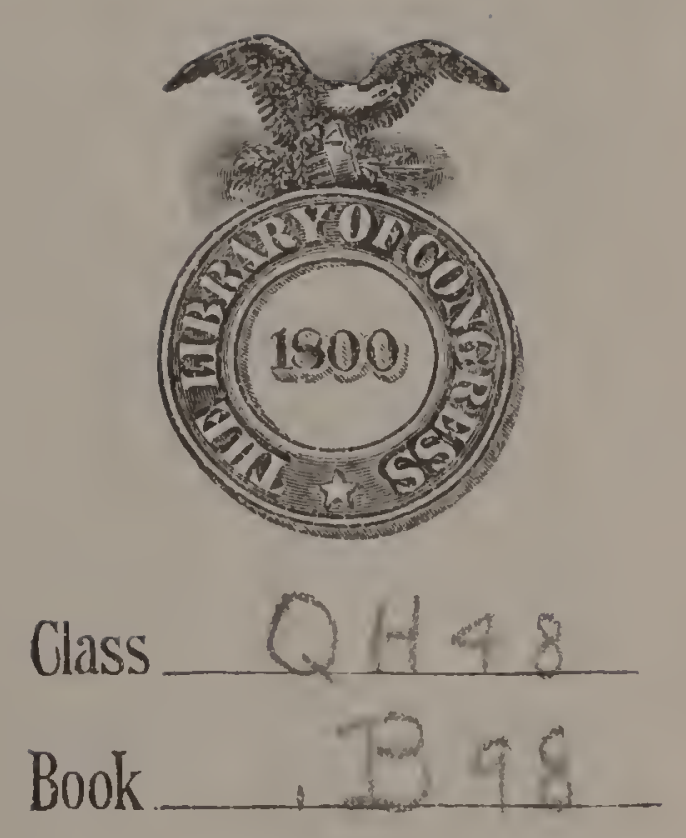

Gopyighlit N

COYYRIGHT DEPOSIT. 




\section{PLANTS AND INSECTS}

ILLUSTRATED

AND INTERSPERSED WITH POEMS

Compiled as Vol. VIII

OF THE

BOYS AND GIRLS' FIRESIDE SERIES

By A. L. BYERS

GOSPEL TRUMPET COMPANY ANDERSON, IND.

Los Angeles, Cal.

Kansas City, Mo.

$1321 / 2$ S. Spring St.

1116 McGee St. 
Copyright, 1921, by

GOSPEL TRUMPET COMPANY

JUN -21921

C) Cl. 4614593 


\section{PREFACE}

The Boys and Girls' Fireside Series is a collection of many excellent and interesting narratives, trips and adventures, little sermons, Bible stories, descriptions of nature, of various industries and of foreign customs, bits of biography and history, missionary experiences, little poems, etc., that have been gleaned from various writers. It is believed that they will form a treasure-store of useful reading in which boys and girls will find both pleasure and profit. 
Some of Their Queel" Ways

The Thirst-Quenching Air-Plant

Some Crawling Leaves

'Two Deadly Foes of the Ants

Ants Have Coinbs

God is Good (Poem)

A Diligent Worker

A Pound of Honey

Ver'y Interesting Tropical Insects

The Song of the Old Oali-Tree (Poem)

The Cotton-Plant

Bamboo

Some National Flowers

Purple and Gold (Poem)

Spiders and Their Webs

Spider-Wiebs

Story of the Fly

Plant Insect-Traps

Ant-Cows

The Hawk-Moths

The Codling-Moth and Plum-Curculio

Some Curious Fellows to Meet

Springtime in the Woods

Useful and Beautiful Insects

A Delicious Fruit

$\mathrm{W}^{-1}$ inged Beauties of the Clover-Field

Song of the Grasshopper

A Destructive Insect

Snout-Beetles and How They Injure Nuts

The Beautiful Roses

Wild Flowers of the Middle West

The Silk-Worm

A Honey-Bee

The Dandelion

About Mosquitoes

Mosquities and Their Boats

The Cacao-Tree

Different Species of the Cactus

A Study of Centipedes

How Mistletoe Affects its Host

Poisonous Plants

Katydids

The Mud-Dauber and its Ways

Interesting Nuts on 'Tropical Shores

O Lovely Autumn Leaves

The California Yucca

Interesting Facts about Nuts

Bananas in Trinidad

The Mango and Other Tropical "Fruits

Out-of-Doors Arithmetic

Beetles

Home Life in an Ant Colony

The Pitcher-Plant

The Millets that Help Feed the World

The Pomegranate

Peculiar Habits of Certain Species of Ants

The Ackee

My First Fxperience with Winged Ants

Propagation of Ferns

The Orange-Tree

Bread-Fruit

The Beech-Tree in Winter

The Night-Blooming Cereus

How I Caught a Butterfly

A Plant that Coughs 


\section{PLANTS AND INSECTS}

\section{SOME OF THEIR QUEER WAYS}

DID you ever watch the clover go to sleep in the evening about dark, and drop their little leaf-heads, for all the world as if they were nodding? The wood-sorrel does the same, and the leaves of the locusttree.

A good many flowers, also, close their petals at nightfall and go to sleep. However, there are owls among flowers as well as among birds and people, who like to lie awake at night and sleep during the day. The night-blooming cereus is one of the most beautiful flowers in the world, when one looks down into its deep cup and sees row upon row of delicate white, waxy petals enfolding each other in such matchless grace, and the hundreds and hundreds of yellow-tipped stamens and pistils forming its heart of gold. But it blooms only at night, and just one night. When the sun rises its pretty petals grow limp and brown and droop over its golden heart. Its beauty is gone forever.

Another curious thing about plants which you may not have noticed is the way they turn the top side of their leaves to the sun or light. If you place a plant in the window, you will find that soon each leaf has turned its greenest face toward the window where the light comes in.

Now turn the pot entirely around, and in a little while every leaf will have twisted itself around, sometimes in what would seem to be rather uncomfortable positions, in order to again face the light.

But the queerest of all plant ways is that of the Dionaea muscipula, or Venus' fly-trap. It grows in the sandy bogs of the southeastern part of North Carolina. At the top where the leaf seems about to end, it spreads out again into a sort of folder like the back of a book, only with a spring in the middle that makes it clap together like a steel rat-trap if the least thing touches it. On the top surface and along the edges are fine hairs, and if a fly buzzing by even touches one of those hairs, "clap" goes the little trap and Mr. Fly is squeezed to death between the two flaps. 


\section{THE THIRST-QUENCHING AIR-PLANT}

A SURVEYING party; in Florida, says the Michigan Christian Advocate, were resting at noon in a forest, when one of the men exclaimed: "I would give fifty cents a swallow for all the water I could drink!"

He expressed the sentiment of the others. All were very thirsty, and there was not a spring or stream anywhere in the vicinity.

While the men were thus talking, the surveyor saw a crow put his bill into a cluster of broad, long leaves growing on the side of a tall cypress. The leaves were those of a peculiar air-plant. They were green, and bulged out at the bottom, forming an inverted bell. The smaller end was held to the tree by roots grappling the bark. Feeding on the air and the water that it catches and holds, the air-plant becomes a sort of cistern. The surveyor sprang to his feet with a laugh.

"Boys," he said, "that old crow is wiser than every one of us. $\mathrm{He}$ knows that there are a hundred thousand water-tanks in this forest."

"Where?" they cried.

The surveyor cut an air-plant in two and drained nearly a pint of pure cold water from it. The men did not suffer for water after that, for every tree in the forest had at least one air-plant, and almost every air-plant contained a drink of water.

-Exchange.

\section{SOME CRAWLING LEAVES}

WHEN Australia was first discovered by the English, many strange tales were told about the new and wonderful things to be found there. Among other things it was said that the leaves of a certain tree at times came down from the branches and walked along the ground.

A party of English sailors had left their ship, to roam along the shore and "see what they could see." They were resting under a tree, lying on their backs and gazing upward, when a sudden breeze shook the tree, and a number of leaves fell from the twigs, turned somersaults in the air, as leaves do, and floated to the ground. The sailors were surprized at this shower, because it was midsummer, and not the time for leaves to fall; besides, these leaves looked fresh and green. It was strange to see them deserting the tree without any reason; but this was nothing to what followed. 
After a short rest, these able-bodied leaves began crawling along the ground toward the trunk of the tree from which they came, and the amazed sailors started up in terror. They took to their heels at once and lost no time in getting back to the boat.

This strange incident has been explained by later traveler's who were not too much frightened to stop and examine the matter. It was discovered that these queer leaves are really insects that live upon the trees, and are the same color as the foliage. They have thin, flat bodies, shaped like the leaves, and when anything disturbs them, like a breeze, they fold their legs away under their bodies, and then the leaf-like shape, stem and all, is complete.

Not only are they bright green in summer, like the foliage of the trees at that time, but they actually change when the leaves do to the dull brown produced by frost. Another peculiarity of these leafinsects is that, although they have a generous supply of wings, they seldom use them, but when they have been shaken to the ground, after lying there a few minutes as if they were really leaves, they crawl toward the tree and up the trunk without seeming to know that they could get back to their quarters in a much quicker and easier way.

- Selected.

\section{TWO DEADLY FOES OF THE ANTS}

$W^{\mathrm{E}}$ read in Gen. 1:25, "And God made the beast of the earth after his kind, and cattle after their kind, and everything that creepeth upon the earth after his kind: and God saw that it was good." It is true also that, having created every animal, bird, fish, and insect, he made provision for food to sustain life; which shows the infinite wisdom of God and his care for all his creatures.

Looked at from one viewpoint, it is hard to understand why the little grub called the ant-eater was created; but when we remember that it is God's handiwork, then we know it is for some good purpose and fills its place in the creation. Ant-eaters are found in different parts of the world, but the little fellow $\mathrm{I}$ have in mind is a native of Australia. The color of his body is a light cream, while his head is brown. He measures three-quarters of an inch in length and onesixteenth of an inch in diameter and his legs are hardly visible to the naked eye. Not a very formidable foe, you will say, and yet when in 
his home on an ant-hill he deals out death to the luckless ants that liappen to pass his way.

The ant-hills in Australia are sometimes very large. The writer has seen them five feet high and fully ten feet in diameter at the base, but generally they are smaller.

While watching the busy inhabitants of an ant-hill at work, we noticed one apparently fastened to the ground and struggling to free itself. An attempt to move the struggling ant revealed the fact that one of its legs was drawn down a tiny hole and that something was hanging very tenaciously to it. The captured ant soon became exhausted and died. It was then left on the ground near the hole with others that had perished in the same way.

There were a considerable number of these little holes in different parts of the ant-hill, and round the top of each was a little white ring. Watching to see what would happen next, we noticed that whenever an ant in moving about over the hill happened to run over one of these holes, up would pop a minute pair of nippers at lightning speed, striving to gain a hold on the ant, and usually succeeding in closing round a leg in vise like grip and dragging it down until the body prevented its going any farther. In about five minutes from the time it was caught, the ant was dead, its life-blood apparently having been sucked out of it. Sometimes another ant will come along to help his mate that is in trouble; but it is of no avail, for just as sure as those nippers close around the leg of the ant, just so sure it is that he will not get away alive.

A peculiar fact about this little grub is that so long as he remains in his hole he is safe, but just as soon as the earth is removed and he is exposed, he is perfectly helpless. The ants seem to realize this; for they will tackle him at once, and it sometimes happens that two ants in struggling for him will tear him in pieces.

Another interesting little insect that plays its part in this direction is a species of ground-spider. The length of its body is only one-third of an inch. It hollows out in the fine, soft earth a conical-shaped hole, about one inch in diameter at the top, and tapering down a depth of about an inch or a little more. The side walls, therefore, are very steep. At the bottom of this hole the spider settles, and buries himself just sufficiently to be hidden from view. There he waits.

Presently a tiny black ant comes along, and, not being aware of the 
trap, makes to go down the steep incline and climb up the other side. But this short cut proves fatal. No sooner does he lodge on the finely powdered wall of the hole than he discovers he has no foot-hold, and he tumbles to the bottom. The spider does not show himself, but by a series of kicks and the consequent flying up of the dirt he works the ant under the soil, where he has him at his mercy. The spider is not always successful in catching his prey immediately; for the ant, realizing he is in danger, strives frantically to escape. But no sooner does he try to climb the wall than down he comes again; for the soil is so fine and light that it rolls. dow'n with his weight. He soon becomes exhausted, and then the spider's task is an easy one.

The traps are laid close to the tracks of these little ants, and many a one tumbles in before it realizes there is a hole, for the brink is so unstable that with the mere weight of the ant's body it immediately gives way. Can any of my young reader's see the le'sson there is in this story of the ants for us?

-J.M. Philpott.

\section{ANTS HAVE COMBS}

YO creature is more tidy than an ant, who can not tolerate the presN ence of dirt on her body. These little creatures actually use a number of real toilet articles in keeping themselves clean. No less an authority than Dr. McCook says their toilet articles consist of coarse and fine toothed combs, hair-brushes, sponges, and even washes and soap. Their saliva is their liquid soap, and their soft tongues are their sponges. Their combs, however, are the genuine article and differ from ours mainly in that they are fastened to their legs. The ants have nol set time for their toilet operations, but stop and clean up whenever they get soiled.

- St. Nicholas.

\section{GOD IS GOOD}

There is music in the air, Joy-notes sounding everywhere;

Robed in summer's beauteous dress,

Perfect in her loveliness,

With a true and tender tone

Blending countless notes in one, 
Sweet and swiftly understood, Earth is singing, "God is good."

Hear the bee's incessant hum

From the heathery moorlands come;

West winds kiss the waving grass, Sighing softly as they pass;

Light and low, their gentle breeze

Whispers through leaf-laden trees;

While above, in blithest mood, Birdies warble, "God is good."

How the sunbeams gleam and glow,

Where fast-ripening fruit-trees grow!

In the meadows reapers gay

Cut and toss the fragrant hay;

Harvest-days will soon be here;

Cor'n is waving far and near,

Grown to give us strengthening food,

Proving still that "God is good."

Nature's sweetest summer strain,

Many voices, one refrain.

Let us too in grateful song

Join this chorus, sweet and strong;

While the birds and trees and flowers

Fill with praise the golden hours.

Children, don't you think we should

Echo with them, "God is good"?

-Selected.

\section{A DILIGENT WORKER}

YOU know what it means to be at the head of your class, do you not? 1 T want to tell you of a diligent little worker that stands at the head of his class. He belongs to the insect class. His name is Bee. He excels all other insects in building and social abilities, in organization. and in intelligence. There are about five thousand kinds of bees, the most important of which is the honey-bee. In southern Asia there are many wild species. Some build comb about the size of a man's 
hand, in the open air, attached to a branch. The swarm stays on the outside of the comb, making it appear black. In America we know the bee mostly as a tamed insect, producing food for man, and it is of this that I wish to tell you most.

It was early summer, and a new family of bees with the queen, their mother, had recently come to an old empty hive in the garden. They immediately set to work, some to clearing the dirt-particles from the hive, and some to laying the foundation for their new home.

Were we able to watch such an operation, we should find it very interesting. A number of the bees hang themselves from the top of the hive. The first ones cling to the roof with their forelegs, and the other's hang with their forelegs hooked to the hind legs of the bees above them. In this way, for a day and a half, they hang like a thick black curtain.

But before bees leave their first home, they eat their fill of honey, and, while hanging, they change this honey into a wax. Just how bees do this, no one knows but the wax appears in little scales between the horny rings of their bodies. These the bee moistens and kneads with its tongue and pincers until a gluey substance is formed.

Then a bee from! the center of the cluster crawls to the top of the hive and deposits and fastens his little budget of wax. This is the foundation-stone of the new home. Other bees do likewise, until a sufficient foundation for the new comb has been completed.

Now comes an architect. He examines the foundation carefully and with his antennæe pats it down here and there. When all is adjusted to suit him, he bores a hole in the center. This is the beginning of the first cell. The cells are six-sided little rooms and so marvelously made that no man has been able to equal them. So diligently, do these little creatures work that it does not take long for them to construct a comb of considerable size. Then real housekeeping begins.

The queen-mother, who has been restless during this time, sets about her work of egg-laying. It is said she lays as many as three thousand eggs a day. As she goes from one cell to another depositing the tiny bluish-white eggs, she is attended by ten or fifteen maids of honor. They caress her with their antennæ, and, when' she will take it, they feed her upon choice honey and bee-bread.

The bee family shows much love to their queen-mother. If famine 
overtakes the hive, she is fed with the best food remaining. If a number of the bees are sent away with the queen in a tiny hive, they feed her as long as a scrap of food remains, and die themselves rather than take food from her.

Summer work in a beehive is very heavy. As the queen-mother lays a large number of eggs, many baby bees have to be fed, the hive kept clean and cool, new comb made, and honey stored for winter'? use. Perhaps you would like to know more particulars about how bees do this.

From the eggs laid by the queen, three kinds of bees are to be hatched-workers, drones, and queens-and the wise mother seems to know the proper cell for each egg. The drones' cells are larger than the workers' cells, and the queens' cells are very unlike the other's. They are usually built at the edge of the comb, and, when empty, resemble acorn cups in appearance.

The tiny bluish-white egg hatches in about three days, but the hatch, or larva, does not look at all like a bee. It is a little worm-like creature, having no feet, and coiledi up like a ring at the bottom of the cell. Gentle nurses supply it with food-pollen, honey, water, and milk from a gland in their head, for five or six days. With this good care the tiny worm grows fat and strong and soon fills its little cell-house. But one day it refuses food. What can be the trouble? Is it ill? No; this is a sign to the nurse to cover its cell-house with a wax roof. When thus shut in, the fat worm-like creature spins for itself a silken cradle. In four or five days it changes its form. It is no more a worm, or larva; it has legs and wings. In six more days it gnaws its way out. Workers clean out its cell, and nurses flock to help it. They caress it with their antennx, and feed it; but it does not usually try its wings for about a week. At the end of that time it is sent to gather pollen or to help clean and keep the hive cool.

The larvæ in the queen-cells are fed with an especially rich food, known as "royal jelly." This causes them to develop into perfect queens, much larger than the worker-bees.

In the summer, keeping the inside of the hive cool is very important. If it grows too warm the little waxen walls become soft and bend. To avoid this calamity, a number of bees called fanners take turns standing at their posts of duty and moving their little wings very rapidly. 
As autumn approaches, the queen lays fewer eggs, and by the end of September she has practically ceased. The hive has many more bees in it than when we saw it at the beginning of summer. As winter comes on, the bees become less and less active and finally enter into a kind of stupor, remaining thus until spring.

Winter past, let us visit our hive of bees again. The diligent little workers have shaken off their stupidity. The queen has started again to laying eggs. Many bees are flocking to the willows, violets, anemones, and other wild flowers, gathering honey. The drones, the idlers of the hive, help themselves to the best there is, and for pleasant slumbers select the coziest corner. They disport themselves on the comb, apparently content with their idle existence.

As more baby bees are hatched, the hive becomes crowded. As time goes on, a new queen hatches and the old queen becomes restless. Her actions cause great trembling among the workers. She seems to be a jealous creature. She has heard the piping of the baby queen and this fills her with murderous intentions. She goes forth to kill the baby queen. The workers guard their baby queen, and if necessary heap wax on the top of her cell to protect her.

The old queen, in some way, makes known her feelings throughout the hive. General work is neglected and fewer bees are seen to leave and return from the hive. The occupants of the hive are about ready for a swarming. This takes place usually on a fine day. It is said a cloud passing over the sun may check the swarm.

But at last the old queen, with about two thirds of the bees following her, rushes forth ready to start a new community. Soon a new queen emerges from her cell and is welcomed by the workers left in the old hive. The nurses caress her and brush and clean her body. In a few days she takes her wedding flight. This is the only time she leaves the hive, except when she leads a swarm.

The drones are her suitors, and there are many of them. But only the strongest can be the fortunate one. The queen has great power of flight, and as she soars higher and higher, the pursuing suitors become fewer and fewer until at last one only is left. With one embrace and a maddened whirl the marriage ceremony is completed. But almost at that instant the groom drops dead, and the widowed queen returns to the hive to devote her time to her household duties - that of laying eggs. 
When the swarming season is over, the remaining workers begin a ruthless massacre and kill off the greater part of the worthless suitors, lest they consume too much of the stored-up honey.

- Eskell L. Blore.

\section{A POUND OF HONEY}

$W^{H E N}$ you eat a spoonful of honey, you have very little idea how much work and travel were necessary to produce it. To make a pound of clover honey, bees must take the nectar from sixty-two thousand clover blossoms; and to do this requires 2,750,000 visits to the blossoms.

In other words, in order to collect enough nectar to make one pound of honey, a bee must go from hive to flower and back again 2,750,000 times. Then when you think how far these bees sometimes fly in search of these clover fields, often one or: two miles distant from the hive, you will begin to get a small idea of the number of miles one of the industrious little creatures must travel in order that you may have a pound of honey.

- Selected.

\section{VERY INTERESTING TROPICAL INSECTS}

I ET me tell you of just a few of our tropical insects that to me seem very curious and exceptionally interesting.

I have before me a butterfly that is known as the blue morpho, and his family easily surpasses any other among butterflies as the most gorgeous in the world. This one is iridescent, changing its colors with every movement of its wings. First I see a deep blue of richest tone, then shading into a lighter hue; it finally looks almost black. Then I turn it away from the sun, and I get a very delicate greenish tinge that is truly wonderful. The spots on the wings are of a rich golden brown, and yet they too change with the altered light. Truly, Mother Nature could not have made a more beautiful butterfly than this one.

There are many different members of the morpho family. I wish that I. could afford to own them all, but, unfortunately, I can not. Huwever, let us look at a few more interesting creatures of the tropics.

Would you prefer to seek after beauty, like that of the emperor 
butterfly or the peacock butterfly? The first named is truly clothed in regal robes, while the second rivals the peacock in arrangement and beauty of plumage. Or, would you like to see some curious creatures that hold our interest because of their odd traits and characteristics? All right, let us seek the latter.

First, I am going to introduce you to our neighbor (I do not say "friend," for this creature is quite suspicious and equally as pugnacious), the bombardier. Brother Bombardier is a highly colored beetle with metallic-green and pitch-black markings. It is because of his color that he is quite conspicuous, and yet why should he stew and fret about being discovered! He can ably defend himself without anybody's assistance. How? Very much as the cuttlefish eludes enemies in the depths of the sea. He shoots a fluid that confuses his pursuer, and, while the latter is gathering his wits together, Brother Bombardier escapes. This is what gives this beetle his name of "bombardier." And not only does the fluid go into the enemy's face, but as soon as it comes into contact with the air it volatilizes, exploding with a miniature report that in itself would startle whatever might be after the beetle. Another curious fact about this beetle is that, while it is fast of flight, it seldom leaves the ground, depending upon its power of running to capture its prey or elude an enemy.

We might call the pugilist of "beetledom" the stag-, hercules-, rhinocerous-, and wolf-beetles. All of these are very strong and hardy fighters. The wolf-beetle is perhaps one of the strongest, although the hercules would give him a beating if he had to do so. But the wolf is a cannibal, and his burrow is littered with legs, wings, and other rejected parts of creatures he has conquered in battle. The stag-beetle has toothed jaws extending beyond the head, looking very much like the horns of a stag. So much does another beetle resemble a quadruped that it is called rhinoceros-beetle.

But one of the most curious is the carabus. This beetle is not the fighter that the others are, but he is wise enough to keep out of quarrels until the proper time comes. He considers that the real favorable time (to him) is when a couple of beetles have locked jaws. Once having done this, none of the above mentioned will let go, and so carabus steps right in and begins to make a meal out of them. He knows that he is safe, for they can not fight except with their powerful jaws, and neither will let go for fear of giving his opponent undue advantage. 
So, in spite of the struggles of his victims, he eats away to his heart's content, often devouring both combatants,

Another curious insect is the scorpion, that venomous creature with a sting in his long, slender tail. This creature has been immortalized in astronomy as the eighth sign of the zodiac, representing one of the constellations.

Curious as it may seem, the most poisonous tropical spider injects a poison that does not trouble the victim until after it has started to course through the veins. This is the casambulga. At first the bite is no more painful than that of a harmless spider of our country; but in about three minutes most excruciating pains shoot through the body and paralysis will follow unless antidotes are right at hand. This spider is one of the most beautifully marked of the tropical arachnidans, with a black body and gorgeous red spots.

I might go on indefinitely and tell you something of the life and habits of the tarantula, centipedes, zancudos, cucuyos, blister-beetles, etc., but there is one little tropical creature that is perhaps the most curious of all. His name is "chigoe," and he is otherwise known as the jigger. You might say he is a flea, and that is correct. But his specialty is burrowing under the big toe of a native who goes barefooted, laying eggs there; and these, when hatched, produce an itching, dangerous, running sore that may result in the amputation of the leg up to the knee if neglected.

-Girlhood Days.

\section{THE SONG OF THE OLD OAK-TREE}

There is music in the treetops As they're swaying to and fro;

Seems to me I hear them singing Of the long, long ago

When, the red men idly wandered $O$ 'er these rugged vales and hills

Listening to the voice of Nature As she murmured in the rills, To her echoes in the breezes As they shook the stately oak; Or beholding her excitement When an angry storm-cloud broke. 
Oft, perhaps, he thought of Nature

When the gentle breezes stirred,

Wondering much, but questioning never,

Why she uttered not a word.

This the treetops seem to murmur

In their song of ancient tone

While I sit so far beneath them

In the woodlands all alone.

Here, perhaps, their old admirers-

Men with skin of redder hue-

Fished and hunted all the day long

As their custom was to do;

But today not e'en the traces

Of their wanderings can be seen,

Though we know they oft have trampled

Where the grass now grows so green.

Listen! heard ye not that whisper?

Came it from yon old oak-tree?

"Pray, do tell me, white-faced stranger,

Where those pilgrims now can be?"

Ah, they're resting, calmly resting

Far beneath their native sod,

Waiting yet to learn the meaning

Of the voice of Nature's God.

-Elsie E. Egermeier.

\section{THE COTTON-PLANT}

OUBTLESS many of the young folks have never seen a cottonplant when it was growing. I was brought up where cotton grows, so I will tell you about the plant. In February or Narch the ground is plowed and marked off in rows three or four feet apart; then fertilizer is put in. Next the seeds are planted by means of a planter, which strows the seeds along the rows. They are put in rather thickly in order to insure a good stand. So when the plants come up, they may be very close together and have to be thinned. Then the ground has to be plowed and hoed to keep the weeds out. There is a great deal of work about growing cotton.

At first the plant looks like a weed. Soon buds begin to form, and 
these open into beautiful blossoms. The first day the blossom is white, the next day it is pink, and the next it is red; then it falls off. After this comes the boll in which the cotton grows. In a few weeks it bursts and the snowy white cotton hangs out. Each boll has four locks, which contain four or five seeds each. When the bolls burst, the cotton is ready to pick. It is picked by hand and put into sacks or baskets. Cotton-picking begins the last of August or the first of September and continues until December or later.

After the cotton is picked, it is taken to a cotton-gin, where the seeds are separated from the fiber. The fiber is then baled; that is, it is pressed together to form a large bundle. After it is ginned and baled, it is sent to a cotton-factory, where it is made into cloth. We should be thankful for the cotton-plant.

-David Williams.

\section{BAMBOO}

7 HIS is a grove of bamboo. Bamboo is very valuable to the Japanese people. It brings a good price and is very useful. The boys have put on their rain-coats and -hats and are now digging with their hoes among the tall bamboos. They probably are looking for some nice, tender sprouts for dinner. When they have found two or three, they will send the little boy to the house with them, and their mother will wash and slice the sprouts and boil them tender for dinner. Bamboo sprouts are very sweet, and the Japanese children are quite fond of them.

But it is the large stalks that the boys like best. From these they can make stilts, whistles, flutes, pop-guns, fishing rods, flag-poles, bows, arrows, swords, and all such things with which a boy likes to play. The girls like it because from it they can make dainty baskets, little cradles, vases, brooms, and all kinds of toy furniture.

The farmer likes it; for it makes good picket fences, water-pipes, and rakes. Then it is suitable for so much of his house that he would be at a loss to know what to use if he did not have bamboo. Hisi wife can also use it for many things. It makes pretty furniture for her house, all kinds of baskets and vases, broom-handles, and clothes poles, to hang the clothes on in the sunshine. She can also find so many uses for it in the garden and hen-yard that she could scarcely get along without it. 
Then the merchant can use it to make yard-sticks, umbrellas, barrel-hoops, market baskets, and many other useful and ornamental articles. Everybody admires it because it grows so tall and has such delicate foliage and furnishes such pleasant shade in summer.

There are several varieties of bamboo in Japan, but the kind in the picture is the most useful. The large sprouts come up in early spring and grow very rapidly. They attain a height of about fifteen feet be-

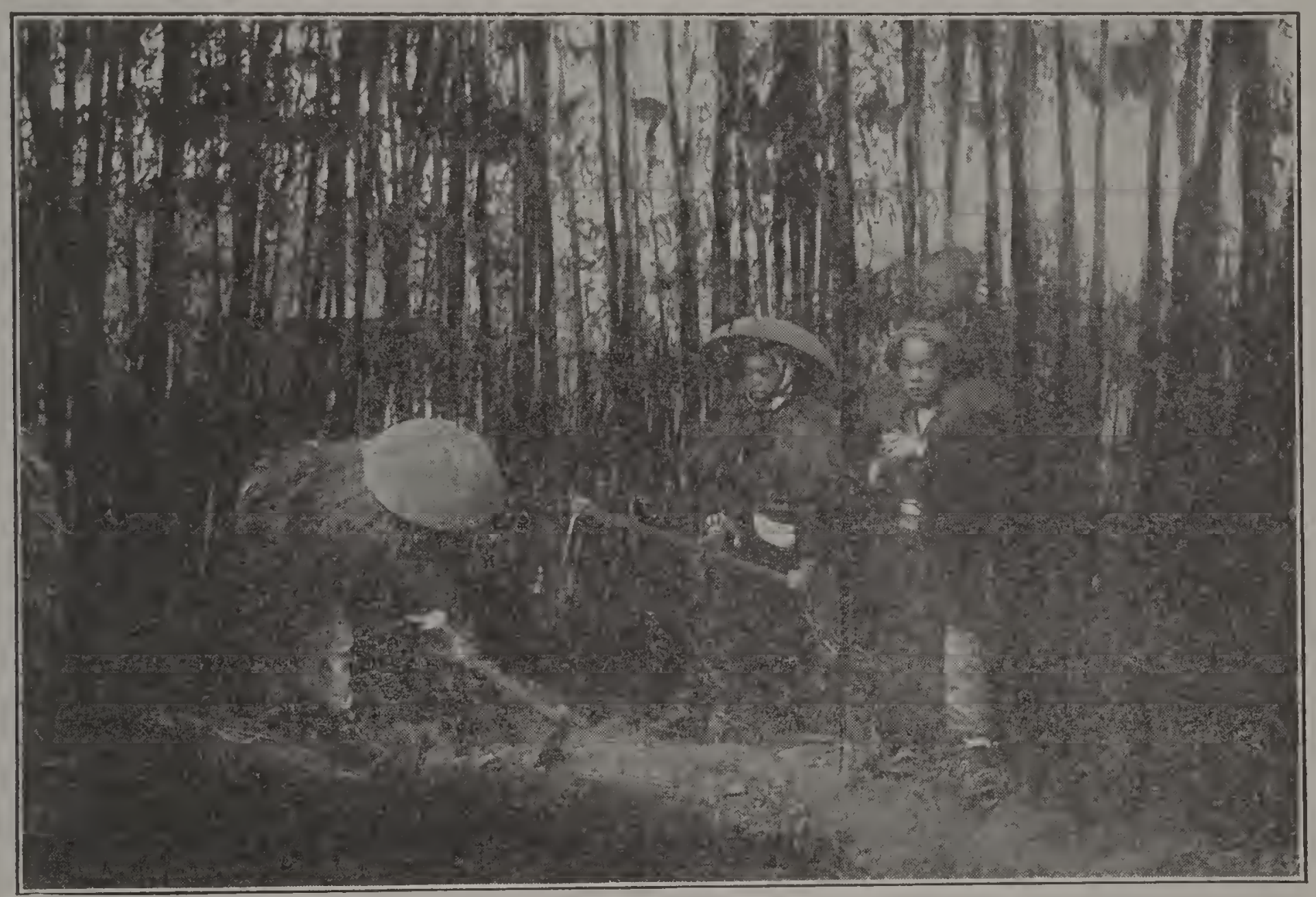

A bamboo grove in Japan

fore they have any branches on them. They are not very attractive until the long, willowy limbs appear, heavily loaded with long narrow, blade-like leaves. Then they become very beautiful.

My, yard-fence is all made of bamboo except the posts, and all the inside walls of my house are bamboo, covered with a black mud on both sides. It is finished on one side by a yellow mud, resembling calcimining; the other side is a brown sand-stone finish. Neither will stand water, and if one were to fall against the wall, he would likely break a hole in it. -W. G. Alexander. 


\section{SOME NATIONAL FLOWERS}

THE rose is the emblem of the English people. On St. George's 1 day, April 23, all those who can, wear roses to show they are proud of their native land.

The shamrock is the emblem of Ireland. On March 17 the Irish people enjoy wearing a sprig of shamrock in memory of St. Patrick, the first missionary to preach the gospel in Ireland. One day when St. Patrick wanted to explain about the Trinity, how there could be one God in three persons, he used the tiny three-leafed plant to show them what he meant. He said, "Three leaves, but one stem; three persons, but one God." So for centuries the shamrock has been the national emblem.

The thistle is the emblem of Scotland. How did it become famous? It is said that a long time ago Northmen undertook to make an attack on Stirling Castle. The invasion was made during the night, and in order to keep from being heard these men were stealing their way barefoot across the moors. One of the men stepped on a thistle, and it hurt his foot so badly that he forgot his stealth and cried out, "Oh!" The watchmen on the castle walls heard the cry of pain, and the invaders were driven back. The attack failed, and the Scotch people were so pleased over this defeat that they chose the thistle for their national flower.

Italy has the lily for its emblem; Wales, the leak; France, the fluer-de-lis (a flower something like the flag, or iris).

What do you know about the national flowers or emblems of other countries? What is the emiblem of the United States of America?

- Opal Brookover.

\section{PURPLE AND GOLD}

On kingly throne, in purple robes

Sat Solomon of old,

And on his lofty brow he wore

A coronet of gold.

A pansy from the lowly soil

Lifts up her pensive face;

Sweet, modest, beautiful, she wears

These colors, too, with grace. 
She did not toil, she did not spin,

Nor did she e'er complain;

She simply grew and bloomed for God,

And he sent sun and rain,

And clothed her there in royal hues

So beautiful and fair

That even kingly robes of earth

With them can not compare.

Oh, let us learn a lesson here

Both beautiful and sweet-

How doth our spirit's garment grow

While we sit at His feet!

We may not do the greater things

That some are called to do,

But we can fill our mission here

By being pure and true.

-Eva E. Andrews.

\section{SPIDERS AND THEIR WEBS}

WHAT human weaver ever produced a fabric equal to the web of these clever little spinners called spiders? Did any carpenter ever build a home so complete, so comfortable, and so perfectly suited to the needs of its occupants as is the dwelling-place of the common spider? Did ever an engineer, after years of scientific training, construct a bridge, a trestle, or a skyscraper that could so successfully defy storm, wind, water, and the strain of constant use for which it was intended as does the web of the little spider?

This little creature, with no school in which to learn his trade, builds his web strictly along geometric lines. He knows nothing about the laws of expansion and contraction from heat and cold, but he makes ample provision against their effects. Swaying limbs, straining winds, or beating rain seldom find his work incapable of resisting their force. The spider's traps, when undisturbed by man, seldom fail to catch and hold the prey for which they are intended.

There are various sorts of spiders in our own country, and in 
fact every country in the world has its variety of spiders. They play a very large part in the destruction of harmful insects the world over. Even in the homes of the city-dwellers they help in ridding the place of

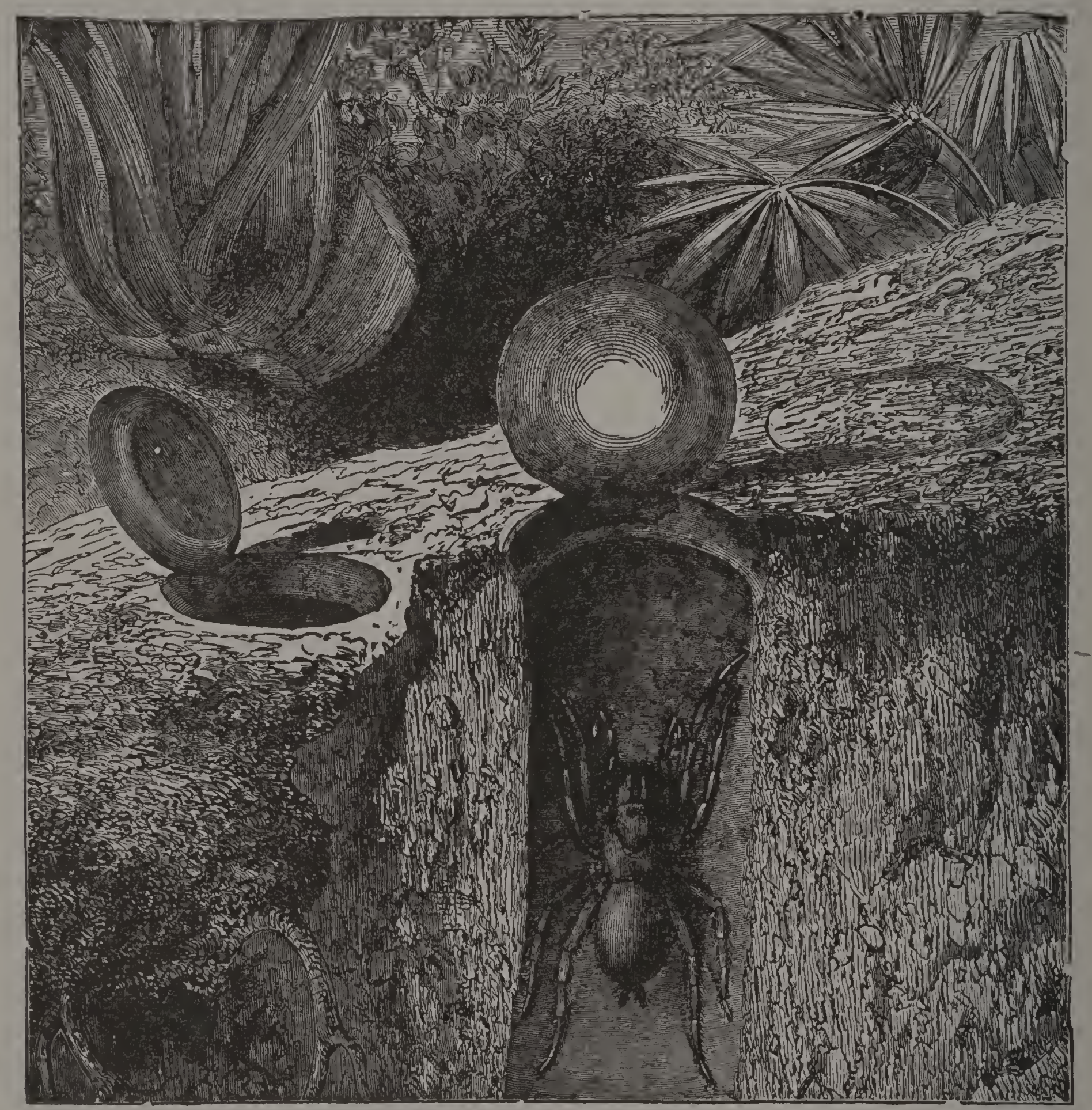

Common or black spider

damaging insects which would otherwise annoy the careful housekeeper. The common or black spiders destroy no fabric by eating holes into it. They harm no plants that are raised for the benefit of man. They harm no fruit. And the stories we hear about their harming people by their bite are usually almost wholly without truth. The tarantula and the 
malmignatte are about the only species in the United States that will harm any one by their bite.

An interesting group are the orb-weavers. These make webs that are circular or partly circular in form, consisting of radii and circular spirals like the spokes and rims of a wheel. Sometimes these webs lie flat, but more often they hang vertically. The spiral lines are the elastic ones, and are usually sticky in order that they may trap and hold their prey. If they were not elastic, they would break when the insect begins to struggle for freedom. Examine a web and notice the difference between the support lines and these elastic spiral threads.

The line-weavers build webs somewhat similar to those of the orbweaver's, but instead of the spiral lines theirs are simply a network of interlaced lines. We see these in the corners of rooms, in barns, and on shrubbery. Usually you will find the spider hanging from the center of the web. Often he will drop by means of his silken thread several feet below the web and there wait for his prey. The moment the web is touched he feels the tremble through his supporting thread and hastens to his dinner. Often he simply hides behind a leaf at some distance from the web, but always carries his warning thread with him. The spider has his spinnerets on the extremity of his abdomen, and it is from them that he spins his web.

The tube-weavers make a tubular or cone-shaped nest with a widespreading net over the top or spreading out from the top. These are often to be found in hedges and fence-rows.

The trap-door spider is a sort of tube-weaver. He burrows beneath the ground and spins his silken net inside of the hole. The tarantula is of this sort also, but he does not make a trap-door. He relies upon his venomous bite to protect himself from invaders; while the trap-door spider, being harmless and timid, makes himself a trap-door for defense.

The tube of the trap-door spider is first lined with a papery' substance similar to a hornet's nest, then the silk comes inside this. Sometimes he builds the trap with one edge thicker than the other so that it shuts by its own weight. But most commonly it is of an even thickness and hung on silken hinges that stretch when it is opened and shut with a snap when he goes in or out. Sometimes this spider builds a second tube, underneath or to one side of the first, with a trap-door. Then 
when an enemy breaks into the first, he finds an empty nest. The spider has gone into the inner chamber and shut the door, which is covered over with silk and not easily to be detected.

When any one attempts to open the trap-door of a nest, the spider grabs hold of the silken lining and braces his powerful legs in the meshes lining the inside of the tube. He will not let gol until his legs or head are pulled from, his body.

Some of the tropical spiders are very brilliant and beautiful in color. Even in our own country the large yellow spiders with brown legs and markings are beautiful if we but lay aside the local prejudice and forget to be afraid of these perfectly harmiless and useful creatures while we take time to observe them.

There are myriads of these creatures that we never see at all. Some are red, some pale green, and some gray. They are so minute that we pass by them unless we especially look for them. Last year we disturbed a web which was literally swarming with tiny yellowish spiders no larger than grains of corn meal. When the web fell on the walk it looked exactly as if some one had spilled a handful of corn meal and the grains had taken to themselves long legs and were walking off.

Some morning when the dew is on if you will walk out into the field or the garden you will see many glistening gossamer threads glittering among the grasses, the shrubbery, and underneath the leaves of the trees and plants. These are the webs of spiders and are unseen until they catch the dew. The larger webs called cobwebs are easy enough to be seen at any time, if you but take the trouble to look about you.

- Selected.

\section{SPIDER-WEBS}

A LL spiders are spinners. It is interesting to note some of the $\mathbf{I}_{\text {jeculiar-shaped webs spun by the different species. The webs are }}$ always constructed with the one object in view, that of capturing food supplies.

Out in some quiet secluded corner you may spy a circular web very finely and systematically constructed. It is a disk of solid silken web with threads radiating from the center to the circumference. You will doubtless find Mrs. Spider seated at the center like a girl at the telephone. 
Mrs. Spider is directing a great number of extra spun lines out toward the circumference of her web. This, no doubt, is to establish communication with all points of her territory.

Finally, a very slight vibration passes over some line, and Mrs. Spider is on the alert. She gives a great tiger spring and clears her feet from her silken web. But the caller at the door seems badly mixed up.

Now is Mrs. Spider's opportunity. She pounces down upon her visitor and gives him so vicious a sting that he is paralyzed. The sting is under Mrs. Spider's jaw. Next she winds her visitor around securely with spun threads, and then she takes him to her pretty little parlor. Mr. Fly never comes forth again.

Another species simply digs a hole in the earth and lines it throughout with a matting of the spun silken threads. Then they conceal themselves in a near-by wall and lie in ambush for a while.

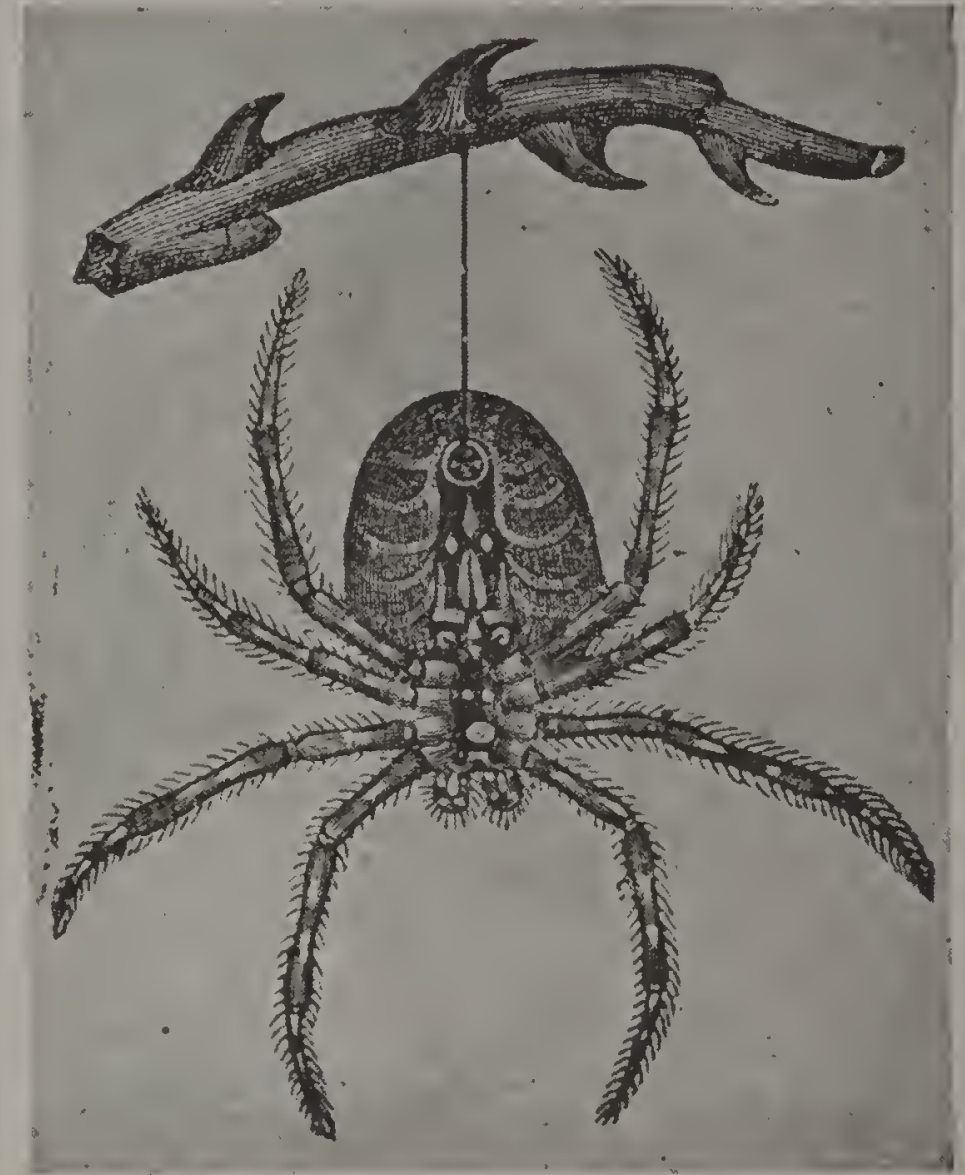

The spider As a stranger insect approaches the conveniently prepared nest, the spider rushes upon him quickly. Thus this spider secures his breakfast, dinner, and supper.

But the most notable is a large spider of Madagascar that weaves a web so strong, it is said, that a light bamboo cane can be laid across it without injuring it.

The idea of manufacturing silk from the spider's silken secretions has been discoursed upon by distinguished scientists for hundreds of years. But it was not until ten years ago that the spun thread of this large Madagascar spider came under consideration. Then the idea of making an experiment with it was conceived. Twenty-five thousand of these large spiders were secured. They were placed in small boxes with their spinnerets protruding. Then the fine, delicate work of reeling off the silken threads directly from the spiders cominenced. At 
length one hundred thousand yards of spun thread, twenty-four double, was prepared for the loom. From this amount of silken thread and warp a yellowish fabric eighteen yards in length and eighteen inches in width was woven. It was placed on exhibition at the Paris Exposition in 1900.

Spiders have the habit of devouring their own kind. The mother spider very tenderly cares for her young. She carries them about with her in a sac until they are old enough to care for themselves. She then pushes them out of the nests. Henceforth they are lawful prey for food. The mother spider would greedily devour her own children could she catch them again.

When any two spiders meet, there is a mortal combat between them until one comes off victorioús. Then he greedily devours his opponent.

This carnivorous element has been the cause of the failure of all efforts to raise colonies of spiders for their silky secretions.

- Sara E. Farman.

\section{STORY OF THE FLY}

MOST FLites live only in the spring and summer months. Some, 1 however, find a place where they can hide and obtain warmth enough to keep them alive through the winter. They hide in cracks and crevices about the house, in out-buildings and stables, where we would not think of looking for them. There they lie dormant, or seemingly dead-sleeping the cold winter days away. But when the warm days of spring come, the fly feels the warmth. It wakes him, and he immediately begins to look about in search of food.

\section{How Fast Do Flies Multiply?}

As nearly all the flies die before winter begins, it seems strange that the following year we have as many flies as ever. But each female fly lays about $150 \mathrm{eggs}$, which require only six or eight days to become fullgrown flies. Then, in turn, the females of these lay their eggs, and within a week another generation is full-grown. So you see flies multiply at an exceedingly rapid rate, especially when there is an abundance of filth in which they may breed. The eggs of the common house-fly are laid in garbage-cans, barns, hog-pens, and any other place that is filthy and unclean. 
In the summer time the eggs hatch into maggots after four or five hours, and in about three days the maggots become full grown and change into pupx, which are a sort of chrysalis. In the chrysalis is formed the body of the new fly, which emerges after a period of from three to five days. Nany eggs are laid in the autumn, but these eggs do not develop and hatch during the winter, as the cold causes the undeveloped flies to stop growing. Some of these exist throughout the winter, and begin growing when the warm days of spring come.

\section{Do Flies Grow?}

When the winter is past and the warm weather returns, the fly inside the chrysalis begins to grow again. At the right moment it bursts open its brown, horny case, and comes out. All that it has to do then is to dry its wings, after which it can fly away full-grown. When we see small flies and large flies together, we must not get the idea that the small ones are young and the large ones old. They are different sorts of flies, but are full-grown.

\section{A Day in the Life of a Fly}

We will now picture a day in the life of a fly. Watch his travels. From the garbage can he takes his rounds into all the unclean places in the neighborhood. After he has gotten his legs and body covered with filth laden with disease-germs, he arrives at the dinner-table, and worst of all, he crawls upon the baby's bottle and upon its sweet face, leaving his deadly discase-germs wherever he crawls, and causes baby's death. The last of our picture tells the saddest story - which is true of thousands of babies throughout the United States each year.

Nothing is too dirty or bad for a fly to eat, and he will carry this filth right into the kitchen and dining-room, and upon your eatables if you let him.

\section{Swat the Fly}

As the fly is one of the worst agents through which disease is spread, it is well that we do all we can to kill his kind. And the best way to get rid and stay rid of flies is through CLEANLINESS.

In many places school-teachers are explaining to the pupils the necessity of killing as many of the flies as possible, and destroying their breeding-places. That the fly is a pest which carries filth and 
disease is proved many times, and we can not afford to neglect our fight against him.

Above all, do not let flies get upon the food you are to eat. You certainly will not if you realize how dirty and dangerous they are.

\section{PLANT INSECT-TRAPS}

WE have all noticed Mother setting tangle-foot and planning different methods for entrapping flies or ants. Nature is engaged in a similar work. We shall mention only three plants, although there are many others. One, known as the Venus' fly-trap and found in the

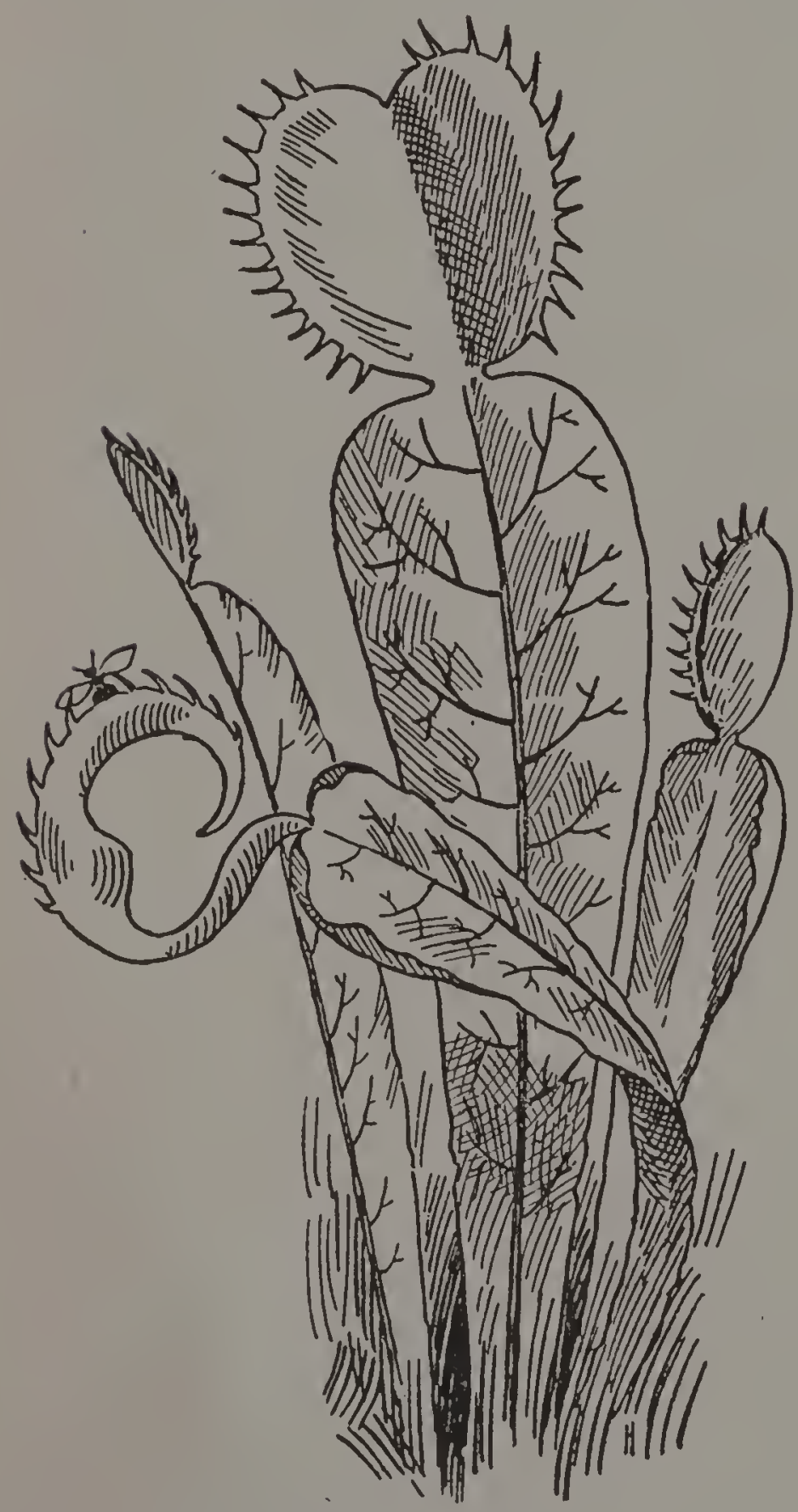

Venus' fly-trap moister parts of North Carolina, traps in a wonderful way and solely for the purpose of sustenance. It has been called by Linæus, Nature's miracle.

The leaves do the trapping. They stand half open, and when an intruder enters they close quickly, thus securing a victim, upon which they feed. Has not nature provided ways at which we must wonder?

Another leaf-trapper is the sundew, which grows in boggy regions. It has a round, somewhat reddish, hairy leaf, covered with a shining, dew-like liquid. This attracts the insects, and when they light on it, they become entangled in its gluey substance. And in the struggle for freedom the little hair-like arms on the leaf clasp the insects firmly, while at the same time the plant issues more liquid, and the leaf edges close up, engulfing the unfortunate insects. The nourishment this plant fails to obtain from the soil it receives by digesting this animal food. 
The leaves are really little stomachs, for just as juices in our stomachs break up and dissolve our food, so does this liquid upon the leaf dissolve the tiny body of the insect into nutrition for the plant.

Still another trap is the common plant known as the dogbane, which glows from two to three feet high, and has small pink and white belllike flowers. It is found in Canada and the United States. This plant, unlike the others mentioned, does not trap in order to sustain life, but apparently to keep away those small insects which can render it no service.

Now the butterfly and the bee are welcomed; for when they insert their long tongues in one of the glands and withdraw, they rub off pollen from the stamens, and on entering the next flower they deposit the precious dust upon a pistil, thus causing seed formation to begin. The small insects are not permitted to carry away the sweet nectar: after supping they find their tongues held fast by parts of the plant and, being unable to get away, are forced to stay and die of starvation. Thus, the plant allows to partake from flower to flower only! those that can assist in its propagation.

\section{"ANT-COWS"}

ONE morning a friend brought me a number of twigs and leaves from various plants, together with a microscope, and invited me to look. And how many wonders even á small microscope reveals!

These plant fragments had on them many tiny insects, some so tiny that with the naked eye I could tell scarcely anything about them. But the microscope showed them to be soft-bodied creatures of various colors, some green, some brown, some pinkish, others spotted or almost colorless. Some had wings, others were wingless. Some had antennae almost as long as their bodies and joined in various ways. Some had tubercles on their sides, others had none. Some had beautifully colored eyes. And on most of them, near the tail on each side of the body was a short tube. These are called honey-tubes; for out of them is excreted large amounts of a clear sticky substance commonly known as honeydew. It often falls upon and varnishes the leaves and stems of plants, or when the wind is blowing it may fall to the ground as a spray.

As a rule, wherever there are ants running up and down twigs, there 
is honeydew, for they like to feed upon this sweet fluid. Ants like also to attend the little creatures that produce this fluid, and for this reason the aphids are sometimes called "ant-cows." The milking of the cows is readily observed. An ant will gently stroke one with her feelers, and the little cow in response emits tiny droplets of honeydew from its tubes, which the ant eagerly licks up. Some species of ants think so much of their cows that they preserve the eggs of the little creatures in their nest over winter and carry the newly hatched aphids to their food-plants in the spring.

These little cows are member's of a large family called Aphididx, or plant-lice. They live on the leaves, bark, or roots of plants, or inclosed in galls. The largest of them is only about one fourth of an inch long, and yet some of them lay eggs that can be seen with the unaided eye.

An interesting study is to gather in the month of October cherrytwig's on which these little aphids are found. Freshen the twigs by keeping them in water, and soon the aphids will gather about the buds ready to lay their eggs. These they usually deposit in the angle between the bud and the twig. At first the eggs are yellowish-green bodies, oval in shape, but later turn to shining black. In the spring these eggs hatch into tiny black wingless females. In about two weeks these give birth to living young that in a few days begin producing young also. Then comes a generation with wings. These leave the cherrytrees for other plants. In the fall winged females return to the cherrytrees, lay their eggs, and the year's cycle is completed. This story is the life story of most of the coinmon species of aphids.

Many of these aphids cause the plant leaves to curl; others form galls on the leaves or stems. Besides this, they suck nourishment from the plants, and injure them with the honeydew, for this forms good "ground" in which various mildews and molds can live.

One way of ridding the plants of these pests is to spray them with various emulsions. Then, there are natural enemies to be encouraged. These are the lady-beetles, dressed in their orange-yellow, black, and red. But one of the most interesting of the enemies for children to study is the little parasite Aphidius. Late in July up until October if you examine colonies of plant-lice you will find some of a lighter color than the rest and much swollen. Put a number of these in a glass, covered with a gauze, and in a few days you will find neat 
little trap-doors cut in the backs of the plant-lice, and minute parasites will be flying about in the glass. - Eskell L. Blore.

\section{THE HAWK-MOTHS}

$\mathrm{O} \mathrm{NE}$ spring day while looking at some pupæ I had keep in a box all winter I noticed that one seemed to have more life than the other's. A mere touch of the finger would cause it to wriggle and squirm from side to side. It was also different in appearance from the rest. It was longer, more slender, and had a more distinctly shaped head than the others. I was anxious to see the adult emerge, so I determined to watch the pupæ closely.

Rather late in the afternoon I noticed that the pupa-case was split near the head on the under side, and I expected the adult to emerge before morning. But there was' apparently little change until the middle of the afternoon next day, when, rather suddenly, at a moment when I happened not to be near, the moth came out and perched itself, head upward, upon a paper.

When I first discovered it, I was astonished at its peculiar appearance. Its downy body was about two inches long, but the larger two of its four wings were not more than one half inch long. Its large head and eyes and the long proboscis curled up in front of the head gave it a rather fierce appearance.

I was much disappointed at seeing the size of its wings; for I had hoped it would be a large, beautiful moth. I placed it in a box and left it for one and one half hours. When I returned to look at it, to my surprize its wings, when spread, now measured about three and one half inches from tip, to tip. They were long, narrow, and pointed, revealing that the insect was a hawk-moth, or a humming-bird moth, as they are sometimes called. These moths may be seen in the dusk of the evening flying about the flower-beds and, by means of the long proboscis, sucking the nectar from the flowers while on the wing, as humming-birds do. When flying they make a sound similar to that made by hummingbirds.

There are many species of hawk-moths, but their larvæ are usually large green caterpillars. One of the most common is the so-called tomato-worm, which feeds on both tomatoes and potatoes. It is a large green "worm" marked with oblique white stripes upon the sides of its. 
body and having a horn upon the tail. When it has reached its full growth, it crawls down the plant and buries itself in the ground, where it forms a pupa and remains all winter.

The pupa is very peculiar in appearance, owing to a long, slender tongue-case, so bent as to bring the tip against the breast of the pupa, looking much like a pitcher-handle.

In the early summer the moth emerges from the ground, mounts some plant, and, when evening comes, flies away.

\section{$-N$. Grace Graham.}

\section{THE CODLING-MOTH AND PLUM-CURCULIO .}

THE boy or girl who has never had the experience of biting into a wormy apple or cherry can be said to have never eaten very many. And these "worms," at which you have scolded, are not worms in the strict sense of the word, but are the larvæ of two insects-in the apple, the larva of the codling-moth; in the cherry, of the plum-curculio, more commonly called the snout-beetle. The plum-curculio sometimes attacks apples too.

The codling-moth appears about the time the apple-trees are dropping their bloom. It is not often seen, for it flies at night, and in the daytime rests on the bark of trees, which it resembles much in color. And, too, it is small, its wing measurement from tip to tip being only about three fourths of an inch.

When examining the wings closely, "one finds that they are crossed by many gray and brown scales and that near the hind angle of each front wing there is a large dark-brown spot streaked with gold. The hind wings are light-grayish in color, somewhat darker toward the margin."

This moth lays her eggs singly, usually on the leaves near the fruit. At first they are tiny white specks, not larger than pin-heads; then they become transparent and gradually turn to a brownish color, finally reaching a black, as the young caterpillars develop within.

In five to ten days they hatch, and the larvæ begin feeding upon the young leaves, gradually making their way toward the fruit. A large majority of them enter the fruit at the blossom-end, but a few enter at the sides where the apples have touched each other or have been rubbed by a leaf. 
Upon entering the apples the larvæ soon eat their way through to the seeds, a favorite place to them. And when you find them, they are about one half inch long, white in color, with black heads and eight pair of legs.

Towards fall these larvæ snugly ensconce themselves in tiny silken cocoons for the winter. Any time from October to May you can find them by scraping bark-scales from the apple-trees. Look, too, for the scales that have been pecked into by the woodpeckers, for underneath you are sure to find an empty cocoon. If you find many that are not empty, that means you have not woodpeckers enough to destroy them.

Knowing how these larvæ damage the apple crops, and how useful birds are in destroying the pest, $\mathrm{I}$ am sure no boy or girl will think of molesting Downy as he hies over the trunks of the apple-trees.

The plum-curculio appears about the time the leaf-buds are opening in the spring. Its body is short and thick, about one fourth inch long, and of a brownish color marked with gray and black. It may be - easily recognized by the elongated hump of what appears to be black sealing-wax on each wing cover. It feeds upon the leaves until the fruit is set. Then, with its long proboscis, or snout, it makes a small hole in the fruit and deposits a tiny, oval-shaped, white egg. 'Then, through wisdom bestowed by the Creator, it cuts a crescent-shaped segment in the flesh of the fruit, around the egg. This makes a dead spot and prevents the crushing of the egg, as the fruit at this point will not grow.

In three to five days the egg hatches, and the larva, as you usually find it, is a footless white grub lying in a curved position. In this condition it stays from twelve to eighteen days; then it leaves the fruit and enters the ground, where it forms a cell a few inches beneath the surface. In this it changes to a delicate white pupa about one fourth inch long and remains thus for about thirty days, when it comes to the surface an adult curculio. In this stage it passes the winter under leaves, grass and trash of all descriptions in and near the orchard, ready for spring depredations.

This little creature is indeed very destructive and equally hard to combat. It has a habit of "playing possum" when disturbed, and until recent years jarring the trees and collecting the insects on sheets spread beneath was the principal way of destroying it. Burning all trash, cultivating the ground, spraying with arsenicals, promptly gathering all infested fruit as soon as it falls to the ground, and allowing chickens to 
run in orchards, are all effective ways of aiding in the destruction of the curculio.

- Eskell L. Blore.

\section{SOME CURIOUS FELLOWS TO MEET}

HOW should you like to meet a larva of a tiger-swallowtail butterfly? H Apparently he has a very watchful countenance, with great, big eyes and a mouth that is ready for anything; but just wait until he moves and starts to eat, and you will see that it is not his face at all! No, this is one of the cases where Mother Nature fools you by giving a weak creature a goodlooking defense! The back markings of the tigerswallowtail caterpillar are very prominent, especially when ready to go into the chrysalis, and you can scarcely find a more ugly chap than he is at that time. He wiggles and twists at the least suspicion of danger, and those "eyes" glare at you furiously. But, as a matter of fact, he is not ugly at all; he is simply uneasy, for he is about to molt for the final time before goingt into the chrysalis, and after that he will come out a flying creature. His real head is safely hidden from view most of the time, except when he is walking about and eating. If you place a ruler below the white line that looks so much like a mouth, he will remind you of an Indian totem of ancient times.

All caterpillar's are very interesting, if you can stand "crawly", things; but there is, perhaps, none better known than the offspring of the black swallowtail butterfly. Your great-grandmother used to call him the caraway caterpillar, because he has a scent like that of strong caraway, and the people of her day used to think this was because he ate so many leaves of the caraway plant, and so became steeped in it. Today we know that this little chap has a pair of scent organs that look like large orange horns, just back of his head, and when he is disturbed he thrusts them out and waves them in the air, scenting the atmosphere very thoroughly indeed.

Another good caterpillar to watch is the baby of the sphinx-moth. There are several of these moths, and, of course, thel same number of species of caterpillars. You have heard of the Sphinx in Egypt, have you not? It is a great stone image that sits, and looks straight ahead. Well, this caterpillar does a similar act when he is in danger. $\mathrm{He}$ raises his head and about a third of his body, keeps perfectly still, and stays that way until danger has passed. In that way he escapes at- 
tention; for birds are careless and do not notice that he is not a part of the branch on which he is resting.

Did you ever see a white moth with humped neck and a pair of long, hornlike feelers? This moth is also conspicuous because of her very long, square-ended wings. Well, she has little children that are called yellow-bear caterpillars, and they certainly do look like just what we call them! When disturbed, they drop to the ground and curl up in a little ball, just as a bear cub does when frightened. When fully grown they are about an inch and a half in length and are very evenly colored. I think that they make the most uneven and irregular cocoons of any caterpillars I have ever seen.

The smallest of the giant silkworm family is known as the bull'seye or Io moth. Its caterpillar is one of the most common over the greater portion of this country. It is one of the most interesting of all "crawlers," because of the many curious little things that it does. Unlike most caterpillars, these fellows march from place to place in a solemn procession, and at a little distance a string of them looks just like some extremely long, hairy worm, creeping on the bark or fencerail. Another curious thing they do is to first lunch from their eggcases soon after they are born. Then they attack the leaves near by. When at rest, these caterpillars. curl up, tuck their heads and tails under their bodies, and present only their backs covered with hairy spines for the world at large to see. When two lines of Io caterpillars meet, the leaders lock heads, rub each other for a ferv seconds, until one gets a seeming advantage, and then the line whose leader won at "rubbing noses" passes straight ahead, while the other line gracefully moves to one side. A prick from the spines of an Io caterpillar is slightly poisonous and very irritating indeed. This is the defense the creature has, and a very good one it is, for no attacker cares for a second injection of spine-poison.

Have you ever seen the young pugilist of caterpillardom? When he is aroused he sits right up and "takes notice," assuming a pugilistic attitude that must seem terrifying to the small creatures that meet him. This is the caterpillar of the polyphemus-moth, and he does this queer stunt by drawing back his brown head so far that the segments of the body, just back of the head, form a large hood that makes the caterpillar look as if he had an exceptionally large head and mouth ready for anything that might come his way. 
Another pugilist is the caterpillar of the pandorus sphinx-moth. He has an attitude that is more that of a saucy little boy with his hands up, ready to strike if he has to do so. He not only draws back his head and raises his body, but his "feet" look like doubled-up fists ready for action. He is not as dignified a pugilist as young Mr. Polyphemus! Because of his swollen shape, this fellow is known as the hog-caterpillar.

\section{SPRINGTIME IN THE WOODS}

. It is springtime in the woods,

The unkept woods.

Though the trees still naked stand-

Stripped of all their beauty grandAs they did through winter's blast Which so recently has passed, Still 'tis springtime in the woods.

See! already swell the buds

On the trees, and bushes too;

Soon the blossoms will peep through.

Snow and ice have disappeared;

Brooks and rivulets have cleared

Rubbish from beneath the trees,

Aided by the roguish breeze.

Soon the unkept woods will be

Nature's fairest spot to see.

It is springtime in the woods,

The naked woods.

Down, down in the ground so deep,

Where the grass and flowers sleep

Through the long, cold winter days,

Have been felt the first warm rays

Of spring sunshine, bright and fair,

Rousing every sleeper there.

Blades of grass begin to grow,

Soon above the ground they'll show;

Flowers too, lift up their heads

From their cozy winter beds;

Buds and blossoms soon will be 
Bursting forth on every tree.

Then the naked woods will stand

Beautified by Nature's hand.

It is springtime in the woods,

The silent woods.

Listen to the robin's note!

Hear him clear his husky throat!

Soon his happy mate will come

From her far-off southern home.

All her friends and kinsfolk too

Will return with much ado;

Then the silent woods will be

Filled again with melody.

\section{USEFUL AND BEAUTIFUL INSECTS}

TO MANY people, insects on plants and trees are creatures to be avoided and destroyed when possible. But some are really beneficial and make war on the harmful ones.

The little ladybird, or more properly, the lady-beetle, has always been a favorite with children. These beetles are often of a brilliant red or yellow color, spotted with black, red, white, or yellow. They spend the winter in colonies under leaves or in nooks in the tree-trunks, etc. One cold autumn day I chanced to pick up a heavy strip of bark. Beneath it were perhaps fifty of these small beetles, sheltered from the cold. They looked cozy indeed, and of course I quickly replaced their shelter.

In summer time they are a foe to the plant-lice that infest fruittrees. Even the undeveloped beetles, or larvæ, are placed right where they can help with the good work.

Among the orange- and lemon-trees these beetles are said to be a help in ridding them of their enemies. In fact, in 1886, when an Australian lady-bird was introduced into California, it destroyed in one year a certain pest.

A very brilliant and showy insect is the lion-beetle. Its body and horny wing-covers are bright iridescent green, blue, gold, and copper. It hunts over trees in search of caterpillars and is said to listen sometimes at the tip of a corn-ear to find whether there is a worm within. 
Its jaws, or mandibles, are strong, and its prey is entirely helpless when discovered.

Another useful insect, though belonging to another order, is the dragon-fly.. It is easily recognized by its four large gauzy wings, very large eyes, and slender body. It is most commonly found about ponds and streams on warm summer days. It is sometimes called the swallow of the insect world; for it destroys gnats, flies, and mosquitoes. The larvæ also rid the water in which they live of many small insects. The eye of the full-grown dragon-fly is a study in itself, being composed of twenty-eight thousand lenses. Small wonder if nothing escapes its vision, and we can never seem to approach it for a closer view.

These are but instances of the wonders of the insect world, to which many learned men have given a life-time of study.

\section{- An Observer.}

\section{A DELICIOUS FRUIT}

THE fruit I wish to tell youl about is grown on plantations in south1 ern climes-Florida, West Indies, Hawaii. It grows not on a bush or tree, but on a stalk not unlike a cabbage-one fruit to a plant. It is brownish-red in color, and sits in the midst of long, green, cactuslike leaves, tipped with crimson. Ordinarily it grows to about ten inches in length and five inches thick, but oftentimes specimens are found that weigh about fifteen pounds. Look at the picture and see if you can tell what this fruit is. If you have never seen it growing, perhaps I shall have to tell you. It is pineapple.

Pineapples as we receive them are a cultivated fruit. They are usually grown in open fields but sometimes under sheds. These sheds are usually a light framework about eight feet high, to which laths spaced about two or three inches apart are nailed, thus covering half the space of the field. Because of the expense incurred in erecting sheds, they are not used except for the finest varieties of pineapples. The sheds protect the plants from heavy or cold winds, frost, the extreme heat of the summer, and help to preserve the moisture.

Pineapples are rarely grown from seeds. They are propagated by setting out the crown, the little tuft of leaves we see at the top of the fruit; by slips, little buds or sprouts looking much like a small pine- 
apple-plant and growing at the base of the fruit; by suckers, young plants growing from the mother-plant at or near the place where the mother-plant emerges from the ground; and by rattoons, which grow from the roots. Sucker-setting is most common, for plants raised from suckers will mature and produce fruit in fourteen or eighteen months, while the other methods take a year longer. Large suckers are always preferred, because they start off vigorously and are less likely to be-

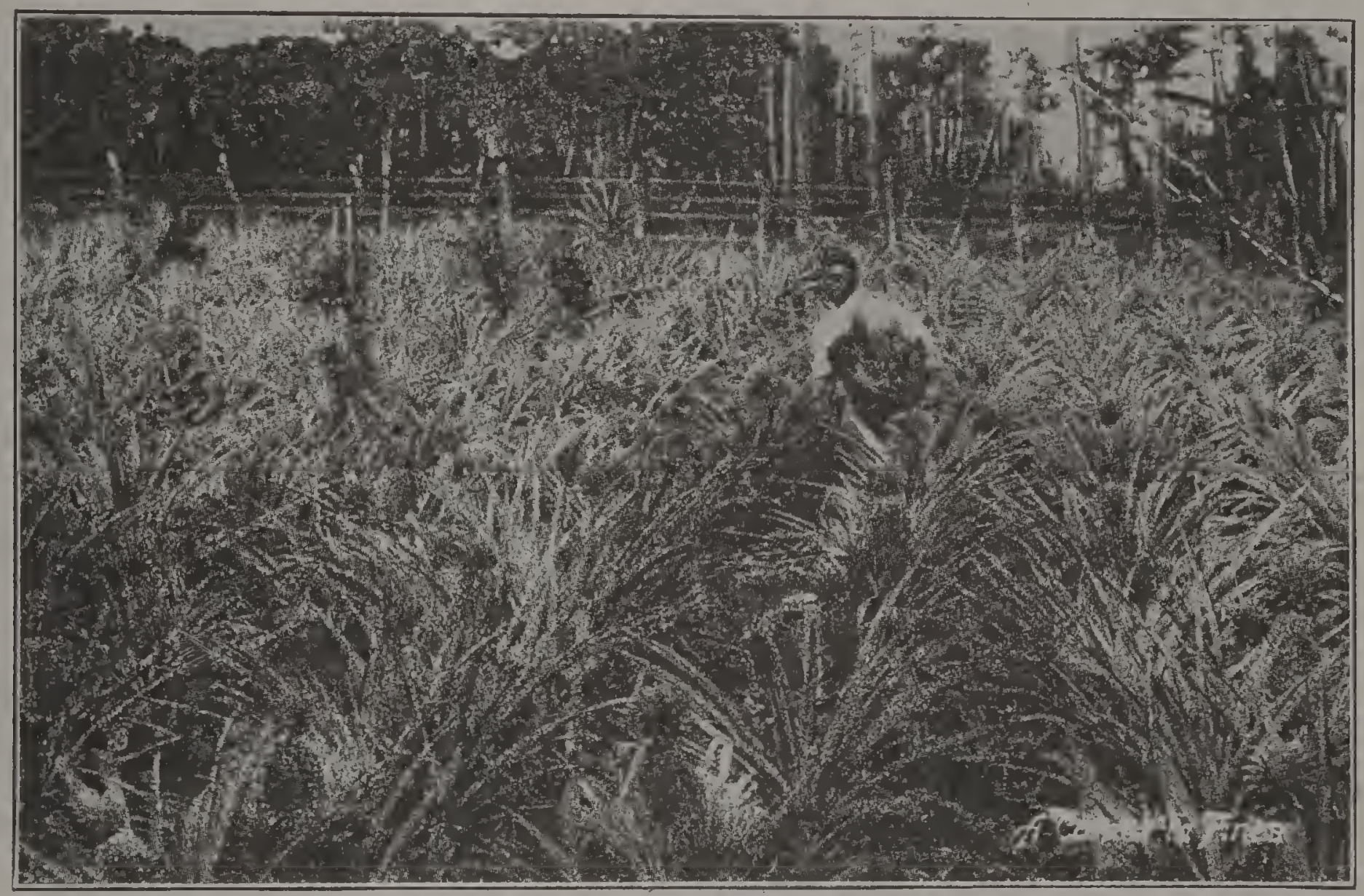

A field of pineapples

come sanded; that is, sand is less likely to find lodgment in their bud and retard their growth.

The soil must be porous, moist yet well drained, and well prepared. If a sandy soil, it must be heavily fertilized, cotton-seed meal being one of the best fertilizers. In many places the fields are laid out in beds ten feet wide with paths five feet wide on either side. These paths serve as shallow drainage-ditches and as a standing-place for the workmen while cultivating. As the roots of pineapples grow so near the surface of the ground, the plants are cultivated with hoes only, and this must be done carefully' lest the leaves be broken.

The plants are set in rows about three feet apart and eighteen to 
thirty-six inches apart in the row. The plants are set from one and one half to four inches deep, according to their size. They must be fertilized frequently, and great care must be taken not to let any of the fertilizer fall into the bud or on the leaves lest they be burned.

The fruit is picked green, about one week before it is mature, and it ripens on the way to market. On account of the spear-like points and sword-like edges of the long leaves, pickers need to be careful lest they pay for their carelessness with badly cut arms and hands.

Usually great packing-sheds are built near the center of the field. There the gathered fruit is carried, carefully packed and nailed up in crates, and made ready for shipment. Sometimes the crowns are cut from the apples for they take up much room, and sometimes the apples are wrapped in brown paper to prevent bruising in shipping.

- Eskell L. Blore.

\section{WINGED BEAUTIES OF THE CLOVER-FIELD}

$\mathrm{O}$

NE bright July morning while visiting in the country I took a butterfly-net and a cyanide-jar and started for the clover-field. I was eager to catch some butterflies; for I had been learning the names of some species, and I wished to catch some that I was acquainted with. I had not been ont long until I saw, flying here and there, a pair of large yellow wings, margined and striped with black.

"A tiger-swallowtail!" I exclaimed. Then waiting until it settled, I slyly stole near enough to catch it in the net. What a beauty it was! I slipped it into the cyanide-jar, closed down the lid, and soon it was quietly sleeping the sleep of death.

Later I removed it and pinned its wings to a board, and after a few hours it was ready to take its place in the collection I contemplated making. It was surely a fine specimen. It measured four and one half inches from tip to tip of wings.

Going farther into the clover-field, I beheld a pretty sight-gorgeously colored butterflies of many descriptions, darting here and there. The silver-washed fritillaries seemed to be most numerous among the larger varieties. At a distance the general appearance of these was a medium brown, but at closer range the top of the front wings showed up darker with heavier black markings, and the hinder wings shaded to a light brown with fewer markings. Underneath the wings were 
many silver-colored spots-because of which this species is sometimes called the silver-spot.

I saw one or two monarchs flying about. They were nearly as large as the tiger-swallowtail I had caught, but the wings were different in shape, and the color was a reddish-brown. The border of the wings was black, variated with white dots, and black stripes ran inward toward the butterfly's body.

The viceroy looks much like the monarch, only it is smaller; but careful comparison of the two shows some difference in the pattern of the markings and the shades of coloring.

Among the more beautiful of the smaller butterflies that I observed were the yellow clover-butterflies. Their wings were clear lemon yellow, with black borders; on each wing of the front pair was a small black spot, and on each wing of the back pair was a small orange spot. There were numerous small butterflies, and some of them were very delicately marked and beautifully, colored.

As I stood and gazed upon these fairy-like creatures, I thought, "How artistically Nature has clothed her children! how wonderfully God's power is displayed in all his creation!"

$-N$. Grace Graham.

\section{SONG OF THE GRASSHOPPER}

I saw a brown old grasshopper, And he sat upon a stone,

While ever and anon he chirped

In a sad and mournful tone;

And many an anxious, troubled look

He cast around the naked plain:

Where now was but a stubble-field

Once waved the golden grain.

What ails thee, old brown grasshopper?

His voice was low and faint,

As in the language of his race

He made this dire complaint:

"Oh! in the long bright summer-time

I treasured up no store;

Now the last sheaf is garnered,

And the harvest-days are o'er.' 
What didst thou, brown old grasshopper,

When the summer days were long?

"I danced on the fragrant clover-tops

With many a merry song;

Oh! we were a blithesome company

And a joyous life we led;

But with the flowers and summer hours

My gay companions fled:

Old age and poverty are come;

The autumn wind is chill;

It whistles through my tattered coat;

And my voice is cracked and shrill.

In a damp and gloomy cavern

Beneath this cold, gray stone,

I must lay me down and perish-

I must perish all alone.

Alas, that in life's golden time.

I treasured up no store

For now the sheaves are gathered in,

And the harvest-days are o'er."

He ceased his melancholy wail,

And a tear was in his cye

As he slowly slid from the cold gray stone

And laid him down to die.

And then I thought: 'Twere well if all

In pleasure's idle throng

Had seen that old brown grasshopper

And heard his dying song;

For life's bright, glowing summer

Is hasting to its close,

And winter's night is coming-

The night of long repose.

Oh, garner, then, in reaping-time

A rich, unfailing store,

Ere the summer hours are past and gone

And the harvest-days are o'er! 


\section{A DESTRUCTIVE INSECT}

I OCUSTS are insects famous in story. From a very early date down to the present they have played a part in the world worth saying something about.

To merely look at a locust in a cabinet of insects one-would not, at first sight, think it capable of being the source of evil to mankind as

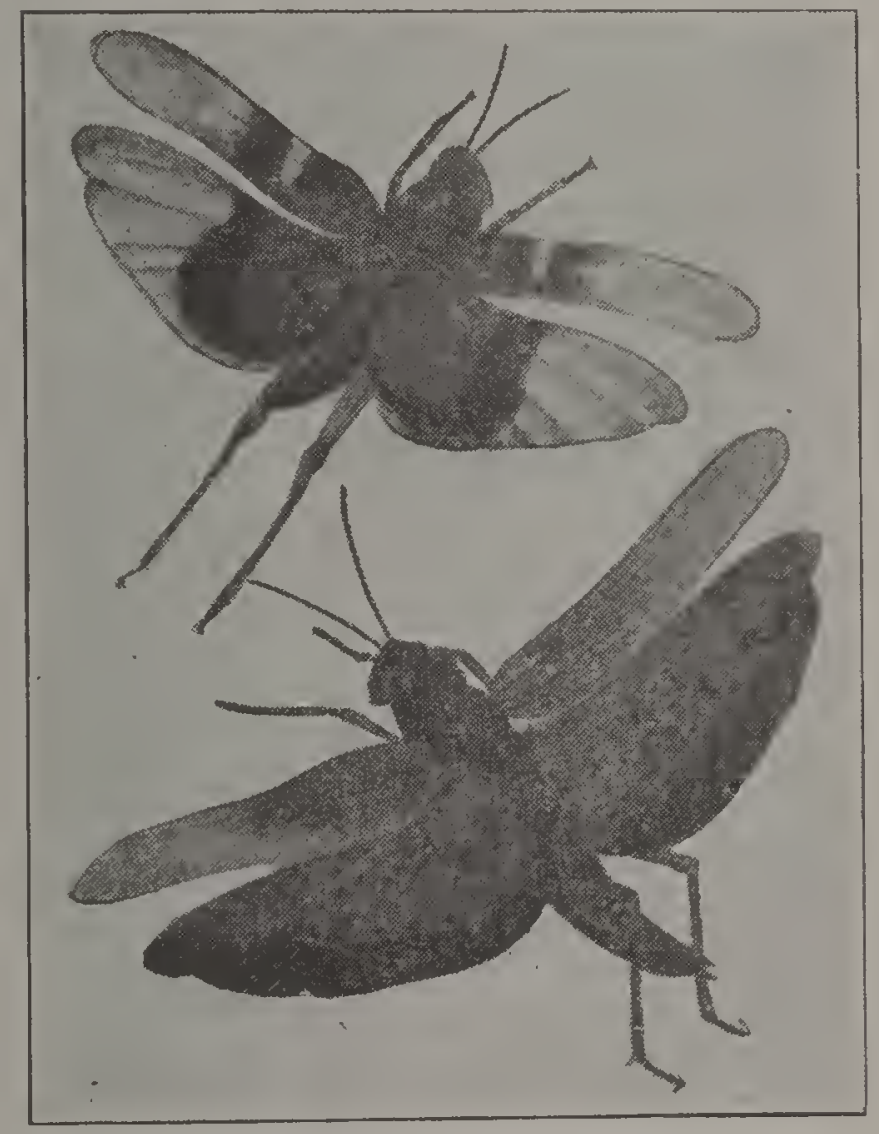

Locusts on the wing stands on record against it. It is but a small creature (some species measuring only a quarter of an inch in length, while other larger species measure as much as five inches), and it would not seem possible for it to do mischief beyond the proportion of its bulk.

There have been many plagues of various kinds of locusts, under which the earth has at different times groaned. In Egypt, Africa, Australia, and various countries of Europe and Asia the air has at times been laden with such numbers of them as to darken the sun, the trees have been bent by their iveight, and the ground covered as with a dark cloth, while the poor people attempted in vain, by shouting, by lighting fires, and by waving branches, to avert the attacks. At such times the noise of their wings and the movement of their jaws has been compared to the rushing sound of a broad river. They eat every green thing in their line of travel; and dreadful famine follows them.

The female locust has a strong boring organ, and with. it she drills a hole in the open soil and there deposits her eggs. In the spring when the sun warms the ground the larve creep out, in colors greenish white or black. It would seem at times as if the very dust of the ground had awakened into life. These tiny creatures begin to move by a process of rolling or twisting. They are sometimes called "twisters."

If they chance to reach the surface when conditions are unfavorable for their development, they build an interesting and ingenious shelter. They bring up from their burrows little balls of mud and place them one 
on top of the other as a mason would lay stones. They smooth the inside as a plasterer would spread mortar on a: wall, close the top, and await a favorable signal to break forth.

Within eight or ten days they can jump four or six inches, and at the age of three or four weeks a desire to "move out and explore" manifests itself. At this age these creatures are yet without wings, but at this wingless stage they are far more destructive than the fullgrown flying locust. They march straight ahead in countless armies, and destroy every green blade in their line of march. If not hindered, they feed and feed until their wings appear, then they rise into the air and continue their progress by flying.

The Arabs have a legend regarding the destructiveness of the locusts. "We are the army, ... we produce ninety-nine eggs; if the hundred were completed, we should consume the whole earth and all that is in it." It is said that the female lays only nineteen eggs, but whether it be nineteen or ninety-nine, we are well convinced of the destructiveness of these creatures.

In flying in enormous hosts, they can be seen coming through the air at a distance of about seven miles. They have been met in a cloud five hundred feet high, 1,200 miles from land. The distance they fly in a day depends in a great measure upon the amount of food they find.

Locusts settling in certain districts change in one season the once beautiful garden country to a wilderness. - Opal F. Brookover.

\section{SNOUT-BEETLES AND HOW THEY INJURE NUTS}

HOW disappointing it is, after we have broken open a smooth, sound1 looking nut, to find that the kernel is worm-eaten and unfit for food! And to make it disgusting, there are, occupying the shell, robust, white or yellowish white grubs with red or brown heads. Where did they come from? And how did they get inside the shell? If the shell of the nut had been punctured with holes, we should have expected the kernel to be bad, although there might be a query in our minds concerning the life of the creature that spoiled it. But the mystery is all the greater because of the apparent perfection of the shell. Let us seek for an explanation in a study of the lives of a certain class of insects known as snout-bettles.

Nuts are attacked by many kind of insects, but by far the most 
serious damage is done by the snout-beetles. There are many different species of these beetles that attack the common nuts of our forests, each species feeding on its preferred nut. It is the larvæ that do the great damage to nuts. Some feed on the husks and inner tissues of young nuts, and others feed on the kernels of nuts that are ripe. Walnuts and hickory-nuts are frequently attacked soon after the blossoms fall from the trees, and the injured nuts fall to the ground before they are half 'grown. Other varieties, including chestnuts and acorns, sustain the greatest injury as they approach maturity.

The name "snout-beetle" is given to this group of beetles because of the peculiar construction of the head, the front part of which is prolonged into a snout or proboscis. The mouth, with its tiny but strong pair of jaws, is located on the tip of the long slender snout. The head is rounded behind, and as one writer says, "fits into a cavity in the front of the thorax forming a union like a ball and socket joint. The construction of this joint permits the head to revolve for more than a fourth of its circumference. In piercing a nut the beetle presses the point of the beak against the surface and by rotating the head drills a tiny opening to the desired depth, sometimes even piercing the horny shell of mature hickory-nuts that are a tenth of an inch in thickness and as hard as bone. After the opening has been made ready, the beetle thrusts forth the long ovipositor and places an egg at the bottom of the gallery. Some species make only one hole in a nut, while others make a branched gallery and insert several eggs through the one small opening in the hull.",

The egg soon hatches; and by the time the nut ripens and drops, the grub, in a number of species, is full-grown and ready to eat a, hole in the shell and emerge. Then it works its way into the ground for an inch or more, where it forms a small cell in which it spends the winter unchanged. In June, July, or August the larvæ change to pupæ. After remaining in the pupal stage for about two weeks, they transform to adult beetles and after a few days emerge from the ground and go to the trees.

This is a very general description of the life cycle of these beetles; there are exceptions and variations in many species.

The grubs that come out of chestnuts about the time they are gathered belong to the group known as the larger chestnut-weevils, which lay their eggs early in the season; those that come out long after 
the nuts have been gathered from the trees belong to a species that lays its eggs just about the time the burrs begin to burst. The eggs are so tiny they can scarcely be seen by the naked eye and are often eaten unwittingly by those who go cliestnutting in the fall. They do not injure the fresh chestnuts, which retain their sweet flavor for a while, and no harm comes from swallowing the eggs the nuts contain. But after the nuts have been stored away for a while, the eggs hatch and

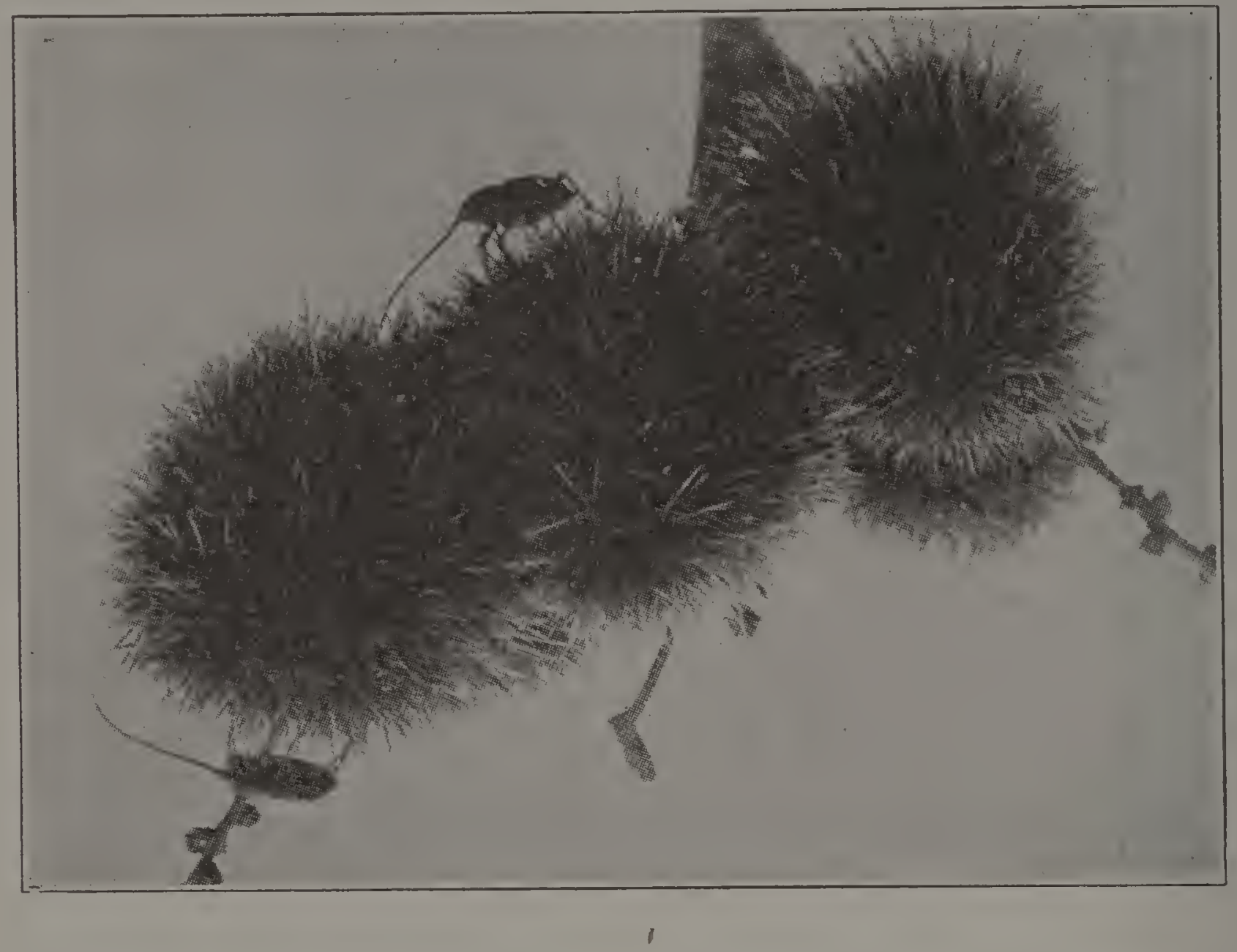

the larva destroy the kernels. When full-grown, they eat large holes in the shells of the nuts and emerge.

Nature has made a very unique provision' among these insects for preserving the race through years in which there are failures in nutcrops. A small per cent of the grubs of each season, instead of changing into adults the next year", remain for two years in their" cells in the earth, then transform into beetles and emerge with those that develop from the previous season's generation of larvæ. Thus, should there be no nuts one year to sustain that year's generation of beetles, there would be beetles anyway the next year to perpetuate the species. Instances have been known in which larva remained until the third year 


\section{THE BEAUTIFUL ROSES}

before changing to the adult stage; this would carry the life of the species over two year's' failure in the nut-crop.

Snout-beetles not only do much damage to a valuable article of food, but greatly hinder the natural development of forests by causing the failure of many nuts to germinate. Much study has been given them by some agricultural experiment stations with a view to finding some method of preventing the destruction caused by them.

\section{$-N$. Grace Graham.}

\section{THE BEAUTIFUL ROSES}

Oh, seo the bright roses!

What pleasures they bring.

They're the handsomest flower

Of all the bright spring.

Their petals are dainty,

Their fragrance so sweet;

Without them the springtime

Would not be complete.

What a bounty of blossoms

The small bushes hold!

Some laden with rubies,

Some studded with gold,

And some, like the lily,

So pure and so white-

All dressing the earth

In a robe of delight.

Our great God hath made these;

His own loving hand

Hath painted each petal

In loveliness grand.

Oh, let us be thankful

For all he hath given.

Since earth is so lovely,

Oh, what must be heaven!

-Mary J. Helphingstine. 


\section{WILD FLOWERS OF THE MIDDLE WEST}

T $N$ the month of March when the bitter winds have ceased and a breath 1 of spring is in the air, the first wild flowers make their appearance. Though the mornings are yet frosty, we find a cluster of low-growing willows with many soft gray "pussies" upon it. How pretty these pussies are! They are always a source of delight to the children, who can not resist plucking a few sprays as they pass. After the April showers, when the sunshine has become warmer and the grass has turned a tender green, blue violets spring up in abundance. Where the ground is moist, the earth is almost blue with them. A very few white ones may be found.

Next the buttercups gleam in the marshy ponds or small streams, usually just beyond the reach of one standing on the bank. The eager children may secure a few, but usually at thel expense of wet feet and muddy shoes. These flowers are very tempting as they glisten in the sunshime, their petals looking like varnished gold. They belong to the Ranunculus family and are the wild cousins of the cultivated varieties.

Under the hedges is the wild oxalis, commonly called sheep-sorrel. It is also pink and white. The perfume of the sweet wild rose now guides us to where they bloom by the roadside. From these have come the beautiful cultivated rose of the garden. Under the stimulation of cultivation and increased food-supply, they have become doubled. As the petals increased in number, the stamens disappeared until in some varieties they are all hidden by the many petals or have given place to them. By various methods of culture different colors have been produced, and the modern rose is found in unnumbered varieties and many colors.

In midsummer bright-colored sweetwilliams bloom in the fencecorners, safe from the mower's sickle, which slays the many white and yellow daisies in the meadows. In the pasture brook are blue and yellow iris, commonly called flags, also the tall, brown cattails, the bloom of the rushes.

Too soon the flaunting banners of the goldenrod remind us of the approach of autumn and of the passing of all transitory things. What is more frail than the bloom of grass? And yet we are told a number of times in the Book of books that "all flesh is as grass, and all the glory of man as the flower" of grass," but that "the word of the Lord endureth forever."

-An Observer. 


\section{THE SILK-WORM}

HAVE you ever visited a silkworm-nursery while the mulberrytrees were putting forth leaves? You probably found an immense room filled with trees and tier's of shelves.

Perhaps one ounce of silkwor'm eggs have been used for the breeding. If so, you will find about forty-four thousand little black "worms" arranged upon the shelves. They are about a quarter of an inch long and housed in little nests of mulberry leaves. They are voracious eaters. Perhaps this is the reason why they grow so rapidly.

These are the larve of the silkworm, and they appear to be very domestic in their habits. They remain very contented in their nests until fully grown. This requires about four weeks. During these four weeks they change their dress four times and devour one ton of mulberry-leaves.

When fully matured the silkworm larva is about three quarters of an inch long and is ready to spin. Branches' and twigs are now arranged about their nests. Presently the larva begin to show indications of restlessness. The quiet little nests are forsaken. The mulberry-leaves have no further attractions. The larvae have eaten sufficient for a long journey and a long nap. For several hour's they travel from one branch to another, up and down, back and forth. Evidently they are house-hunting. Finally they settle down one after another, and the city is quiet again. Now the spinning begins.

The material for spinning is carried within their bodies, and also the spinning-wheel. This consists of two small glands situated at the lower end of the body. Each gland has a tube conductor extending through the entire body. These tubes terminate in small open canals on the lower lip of the mouth.

Now the spinning-match has begun, and every spinning-wheel is set in motion. A faint, buzzing noise is heard when you are attentive to the sound. A fine silvery thread issues from each canal, making a double strand. The threads harden as they come in contact with the air.

They go on spinning, carrying the threads from head to foot until the body of the worm is entirely surrounded. Then they spin an inside layer and still another until there is no longer space nor material for farther work. Now the buzzing ceases, and the little spinners nap. 
From the forty-four thousand larvae, about one hundred and fifty pounds of cocoons are produced. The cocoons are about the size of pigeon eggs.

After a careful selection of the best cocoons is made for future breeding, the rest are put into shallow basins of warm water to kill the chrysalises. Then these cocoons are carefully brushed back and forth. This loosens and dissolves the gummy matter which holds the fibers together and catches the ends of the silken threads as they are liberated. The threads are then reeled off, four or five in a strand, ready for cleaning and twisting.

Each cocoon supplies about three hundred yards of silken thread.

The cocoons for future breeding are placed upon cloths and subjected to gentle heat. In about two weeks the moths appear. They dissolve the gummy matter of the cocoons with their saliva and push their way out of their prison-house.

The silkworm moth is very shortlived. It never leaves the cloth upon which it first rests. It dies almost immediately after depositing its eggs upon the cloth. Twenty ounces of cocoons will produce one ounce of eggs.

- Sara E. Farman.

\section{A HONEY-BEE}

Coming from work in the evening,

All worn with the toils of the day,

Glad that our duties were finished,

We wearily tramped on our way.

Crossing our path then we saw her,

And watched as she hastened along;

Her load, I am sure it was heavy;

fler journey, it must have been long.

Wee bit of life, she had labored

Since first gleam of sunlight at morn;

No one can tell all her struggles,

Nor how many loads she had borne.

Quietly, swiftly, she passed us,

Swinging low in her homeward flight, 
But it pleased us much to meet her,

Though but for a moment in sight.

We could but linger to praise her-

The good, little, hard-working bee,

Willing, contented, and happy,

And-gathering honey for me.

-Annie M. Abbey.

\section{THE DANDELION}

YOW we should miss the dandelions in the spring if they should 1 fail to make their appearance! Along the roadside, in the meadows, in the lawn, even between the bricks of a wall-everywhere we see this golden flower. How many of them there are! What a beautiful sight is a green meadow dotted with the yellow dandelions!

Because the dandelion is so common, few persons admire this really beautiful flower. If it were rare, it would he prized. But it is far from rare. In our lawns it comes, and there it is not welcome. Getting rid of it is not an easy matter. We may dig up the plants, root and, branch, and in a year or two we have the task to repeat.

Though unnoticed, or noticed only to be scorned, yet the dandelions bloom on beautifully. Do we, when unnoticed or when regarded with contempt, continue to show forth the beautiful spirit of Christ?

Dandelion's leaves are used as food and are called greens. Some persons like the blossoms also when cooked and seasoned properly.

We speak of the dandelion blossom as one flower, but in reality it consists of many flowers-perhaps two or three hundred. Each has one petal, one stamen, and one pistil. If we have a stamen and a pistil, we have a flower. Pull a blossom apart (lengthwise). Then pull off one of the yellow petals. You will pull with it a stamen and a pistil. At the bottom of the pistil you can see the seed. Notice the fine white hairs at the top of the pistil.

The flower-head closes at night and opens in the morning. By and by, when the seeds are ripe, the head does not open, the stamens and petals wither and die, the pistils become longer, thus causing the fine white lairs to flatten out. Now, as we look over the meadow we see the hollow dandelion stems clowned with white balls instead of yellow blos- 
soms. If the dandelion stem was short, it now grows longer so the white ball can be easily caught by the wind.

A breeze comes across the white ball and sets the seeds sailing through the air like tiny balloons. Each seed has a parachute of silky hairs over it, which causes it to float. Down, down the seed slowily comes and soon is ready to wriggle to the ground. There it germinates and makes a new dandelion. You will not be surprized that the dandelions spread rapidly when I tell you that I counted on one white ball two hundred and twenty seeds, and the wind had blown off some before I began to count.

\section{ABOUT MOSQUITOES}

HAlVE you ever examined a mosquito under a microscope? By so 1 doing you can know the male mosquito by the feather he wears in his cap. It is quite pretty and stands up high and smart. It branches out like a twig on a tree. It is thickly covered with bristling hairs; so are his long feelers. But he has no lancet about his mouth like the female mosquito. Perhaps this is why the male mosquito never bites.

He sips the sweet juices from the fruits and flowers, and joyously dances in the sunlight all the long summer day. He seems to have a happy, easy life.

It is the female mosquito that sings about your ears at night. She sings with her wings instead of her throat. It is the flapping of her wings that makes the song. Three thousand times in one minute. That is very quick time, but it is the way she trills her deeper notes.

The mald mosquito sings, too. He sings with those bristling hairs on his long feelers. He makes them vibrate very rapidly. His song is like the work done with a tuning fork. So he keeps his song in harmony with the song of his mate.

But it is aiways the female mosquito who bites you. If you could just see her lancet under a microscope, you would not wonder that her bite hurts. She is after her food and she does not care much for the sweet juices.

She leaves her eggs floating on a pool of warm, stagnant water. You will see three hundred or more fastened together like a little canoe. By and by they hatch out; then the water is full of little black wrigglers. How fast they wiggle their little black tails! This brings the small 
particles of food within their reach. How they keep coming on top of the water! This is to get a breath of fresh air. At times they rest from their active wriggling. Then you will see them hanging from the surface of the water with their heads down.

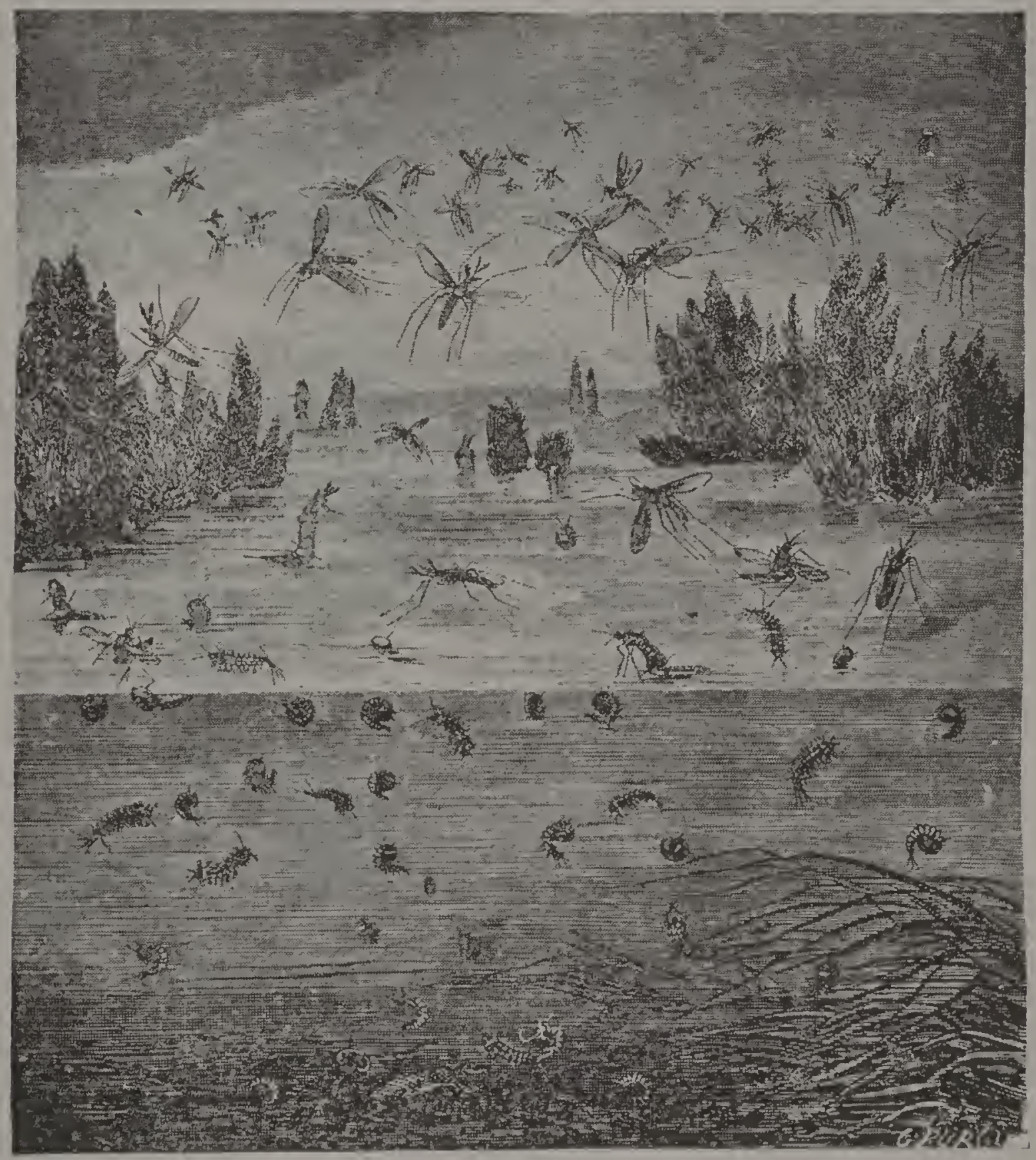

In about three weeks they begin to change. They are still active, but they no longer take any food. After a few days in this new life you will see them come to the surface, and if you continue to watch them, you will soon see the skin on the upper side burst open. Then out flies a full winged mosquito.

"Did God make the disagreeable little mosquito? you ask. "Is there any. good in a mosquito?"' you further inquire. 
Yes, God made everything that has life, and every creature was made for some good purpose, though we may not in every case discover that purpose. Mosquitoes are very excellent food for the dragonfly, and the tiny eggs are greedily swallowed up by the little fishes in the pool.

\section{MOSQUITOES AND THEIR BOATS}

THE little mosquitoes that are so annoying to us during the hot 1 months of the year, have long bodies shaped like a tube. When they lie very still, their wings are crossed in a peculiar manner. When we are able to examine these little creatures through a powerful glass, we find them really quite pretty. The edges of their wings are covered with scales shaped like long plates and delicately marked, very much like fishes. Their feelers seem to be made of the finest feathers, and their eyes are so big that they cover the whole head. They look like lace, and their color changes from green to light red when exposed to the sunlight.

When a mosquito gets ready to bite a person, he uses a trunk, or "proboscis," resembling the lancets to be found in a doctor's case. This trunk is a tiny tube, split from end to end so that it can be easily opened. Inside is a great bundle of stings that looks like needles. They are very sharp, with five points, and bent like a crochet-needle. They convey a drop of poison to the blood of the person that the mosquito has chosen as his victim. When stung by a mosquito, it is always best to give the little pest time to draw the hooks out. The sting then is not nearly so severe as when the insect leaves the five poison-hooks in the flesh.

Now, these troublesome little insects are very remarkable boatbuilders. They lay their eggs in the water and these eggs float until the time comes for them to hatch. If you watch very closely, you may see these tiny egg rafts on any pool on a bright summer's day.

These eggs are so heavy that one would not float by itself, so the wise mother joins them. all together until they make a hollow boat, which will not upset even though filled with water. The upper end of these eggs is pointed and looks like a powder-flask. One egg is glued to another, pointed end upward, until the raft is done. It takes from two hundred and fifty to three hundred eggs to make this won- 
derful boat. When the young are hatched, they always come from the under side, and leave the empty craft afloat.

\section{THE CACAO-TREE}

I T is very interesting to study the tree from which the world gets its chocolate. This is the cacao-tree. These trees grow somewhat like

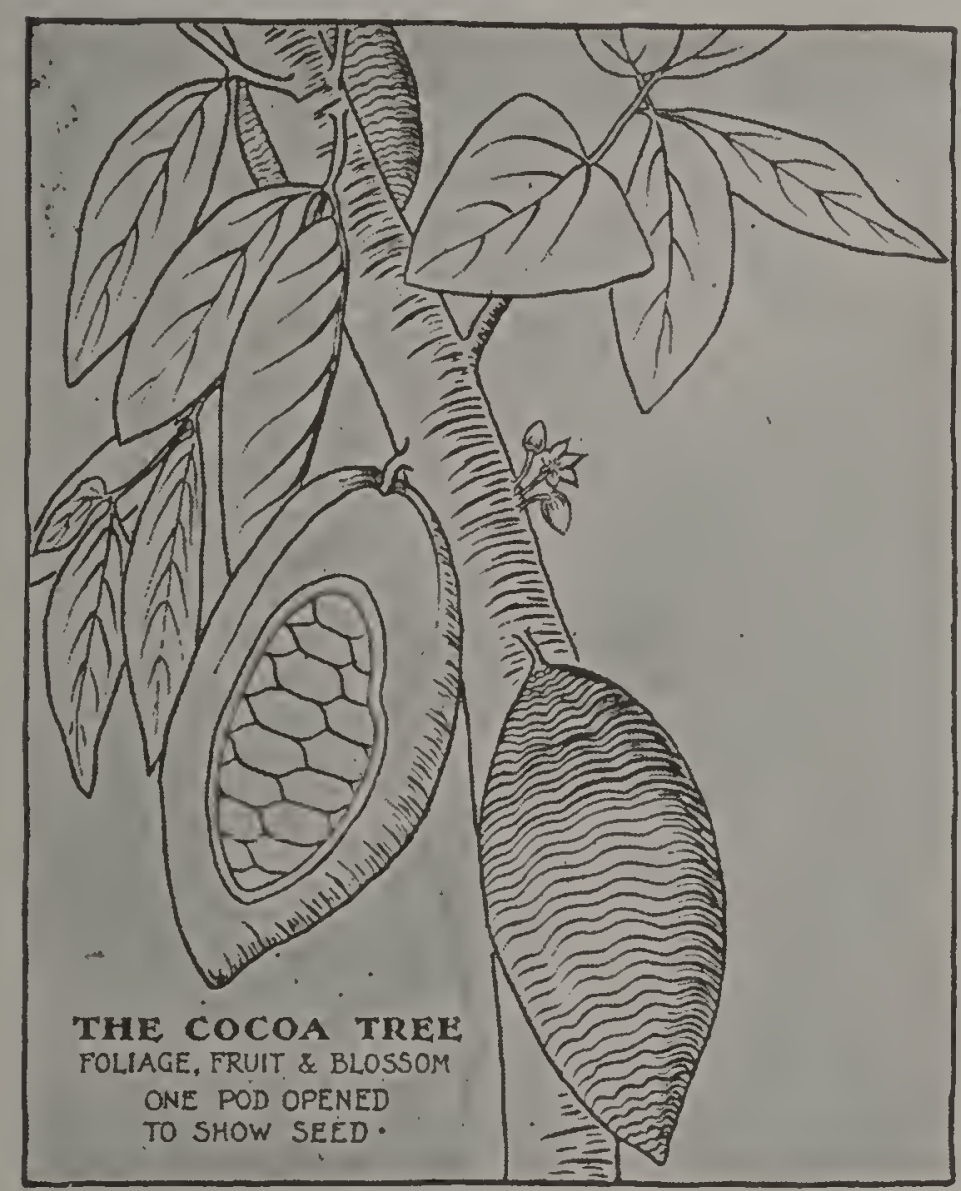
shrubs and reach a height of only ten or twelve feet. They thrive best in shady places, and it is on this account that they are selected to be planted between banana-plants to utilize the ground and also to take advantage of the shade offered by the wide-spreading banana-tops.

The foliage of the cacao-tree is of a rich lustrous green, and its blossom is waxy white. As you will see by the drawing, the fruit grows upon the main stems and trunk of the tree, and is a very curious sight, indeed. When full grown the pods are seven or eight inches long.

The bean from which the chocolate and cocoa of commerce is manufactured is the seed that grows in the pods. One pod is represented here as having a slice taken from its side so as to show the compact layers of seeds within. At first the pods are green like the leaves, but as they ripen they turn yellow. The careful cultivator will cut the pods from the tree instead of pulling them off, since it would be easy to injure the joint from which sprang the fruit-bud and thus prevent any more pods from developing at that same place. When the cacao-beans are taken from the pods, they are enveloped with a thick, white, slimy covering, and the beans are first put away to sweat or ferment the moisture away. Should this moisture not be allowed to drip off, the beans would sprout and grow. When fermentation is complete, the beans are spread out to cure in the hot sun on the barbecue. This is the name given to the drying-place, and it may be seen before the door of 
almost every native home in the country parts of this island-Jamaica. It is a place prepared on the top of the ground by scraping off the top soil, which leaves a flat, hard surface, and is neatly bordered by a frame of wood. This provides an excellent place upon which are spread coffee, chocolate, pimento, and other seeds or fruits that are to be dried or ripened in the hot sun. When the cacao-beans have been thus thoroughly dried, they are ready for export. By various patented processes abroad, the delicious chocolates and cocoas of commerce are produced.

But the natives use the cacao in its original state as a beverage and prefer it to the imported products. It might be of interest to you to leam how this chocolate is prepared here for the table. F'irst, rou will notice, that it is called cacao while it is still in its native state, but as a rule it is called chocolate as soon as the kernel is broken for use. The beverage is caller chocolate here also. The native takes the cured cacao and by subjecting it to heat over the fire parches it. This makes the outer skins easy to pinch off and leaves the cacao-bean clean and ready for use. It is then placed in a mortar and beaten into a fine powder. After it is cooled, they mix in sugar and spices and mold it into little cakes. These will keep any length of time. When needed, the cake is grated and the chocolate boiled as a beverage. It is delicious even in this way when it has been properly prepared. -Nellie Olson.

\section{DIFFERENT SPECIES OF THE CACTUS}

THROUGHOUT the arid and semi-arid regions of our country, or those which comprise the great plains east of the Rocky Mountain system and the desert plains west of the Rockies, the cactus in all its many forms and shapes is considered the commonest of plants.

On the prairie lands of T'exas, Oklahoma, Kansas, Nebraska, and the Dakotas, a small species grows in abundance, almost hid away in the scrubby grass. Sometimes a single plant not more than one fourth of an inch in diameter can be found far from any other of its kind, and again cluster's are found in which as many as twenty-five distinct plants or portions of plants are huddled together as if one plant. A plant of this species, with its roots, is shown in one of the illustrations.

There is something beautiful in this form of cactus. Its needlelike thorns grow in perfect star-like cluster's, which remind us of the 
perfectly formed snowflakes that only Nature can make. These needles, however, are so sharp that it is no uncommon thing when they are stepped on for them to penetrate through the leather of shoes and boots.

When a boy running barefoot upon the prairies, the writer had almost countless encounters with these plants. It is needless to say that

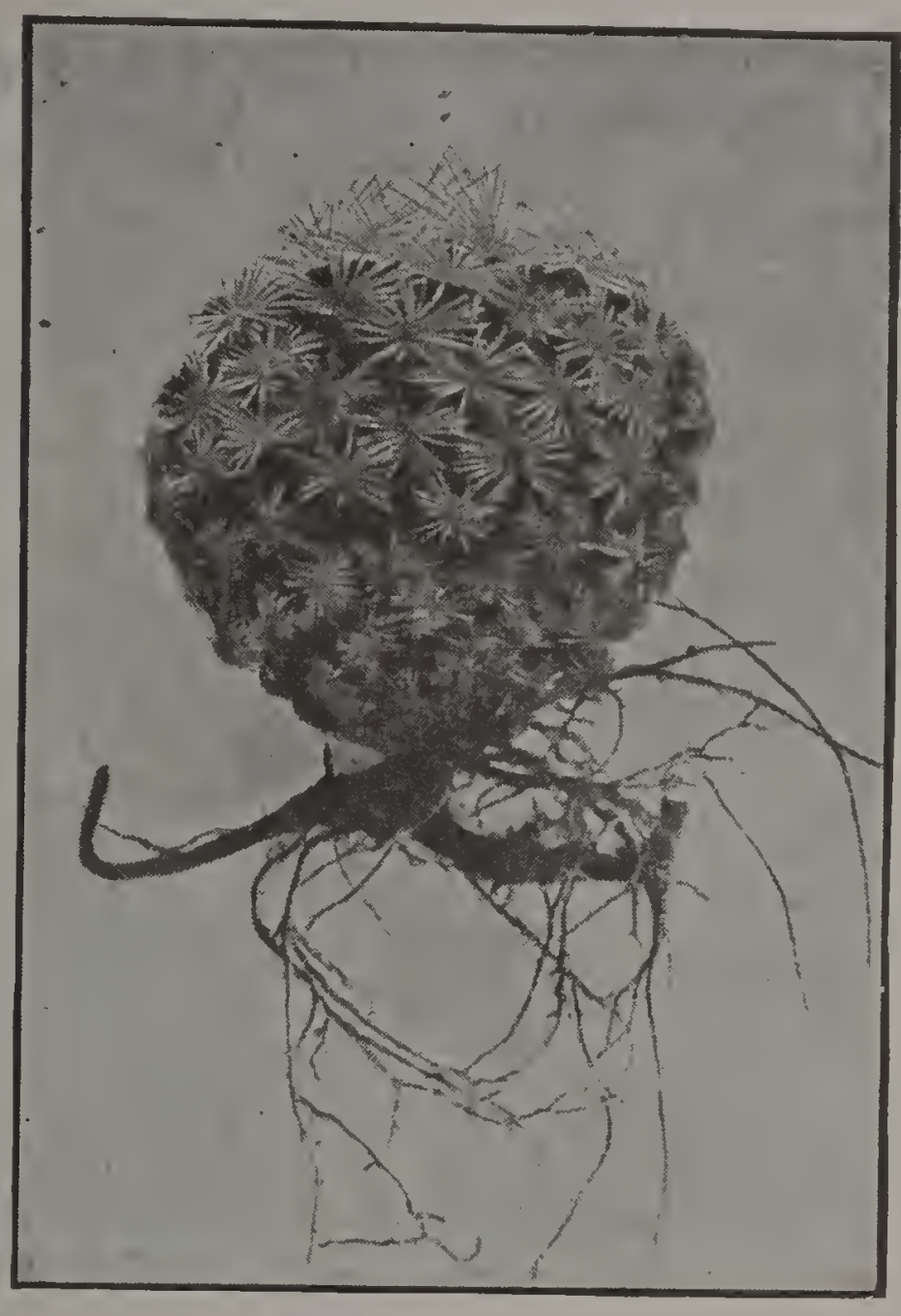

A common small cactus the memory of them is unpleasant. The flowers of this plant are of the most beautiful and delicate shades of pink, and there is no prettier sight than the broad prairies covered with these cheering blossoms.

Along the creek-bottoms in the same locality is another species with broad, thick, leaf-like branches. These grow more in taller grass and are often bit off with a cluster of grass by cattle while grazing. My first experience with anything of this kind occurred while I was herding cattle in my early boyhood. One of the cattle, getting a bite of cactus in its mouth, began to bellow in a furious manner and to paw the earth, while the rest of the herd also came running and bellowing. This was kept up till the unfortunate animal managed to get the cactus out of its mouth. The broken-off thorns made its mouth sore for weeks.

The two species just mentioned are the commonest kinds and are probably found over more area of the prairies and plains of the eastern slope of the Rockies than any other species. Still the cactus family is very large, and there are, species of almost every shape and size. Arizona perhaps contains the largest variety. In this state is found almost every member of the cactus family from the diminutive "fish-hook" to the giant saguaros that grow to a height of fifty feet. The latter cactus is the official flower of the State.

The tall saguaro (see the illustration) is very common in Arizona. It bear's a very beautiful blossom, which is always on the very top: In 
fact, you will notice that the house-plant varieties of cacti produce the blossom either from the tip of the growth of the plant or from the extreme tip of the branches, as does the night-blooming Cereus.

The barrel cactus, receiving its name from its shape, is also very common in Arizona and southern California. It not only is shaped like a barrel, but often also resembles one in size.

In the arid valleys and rocky

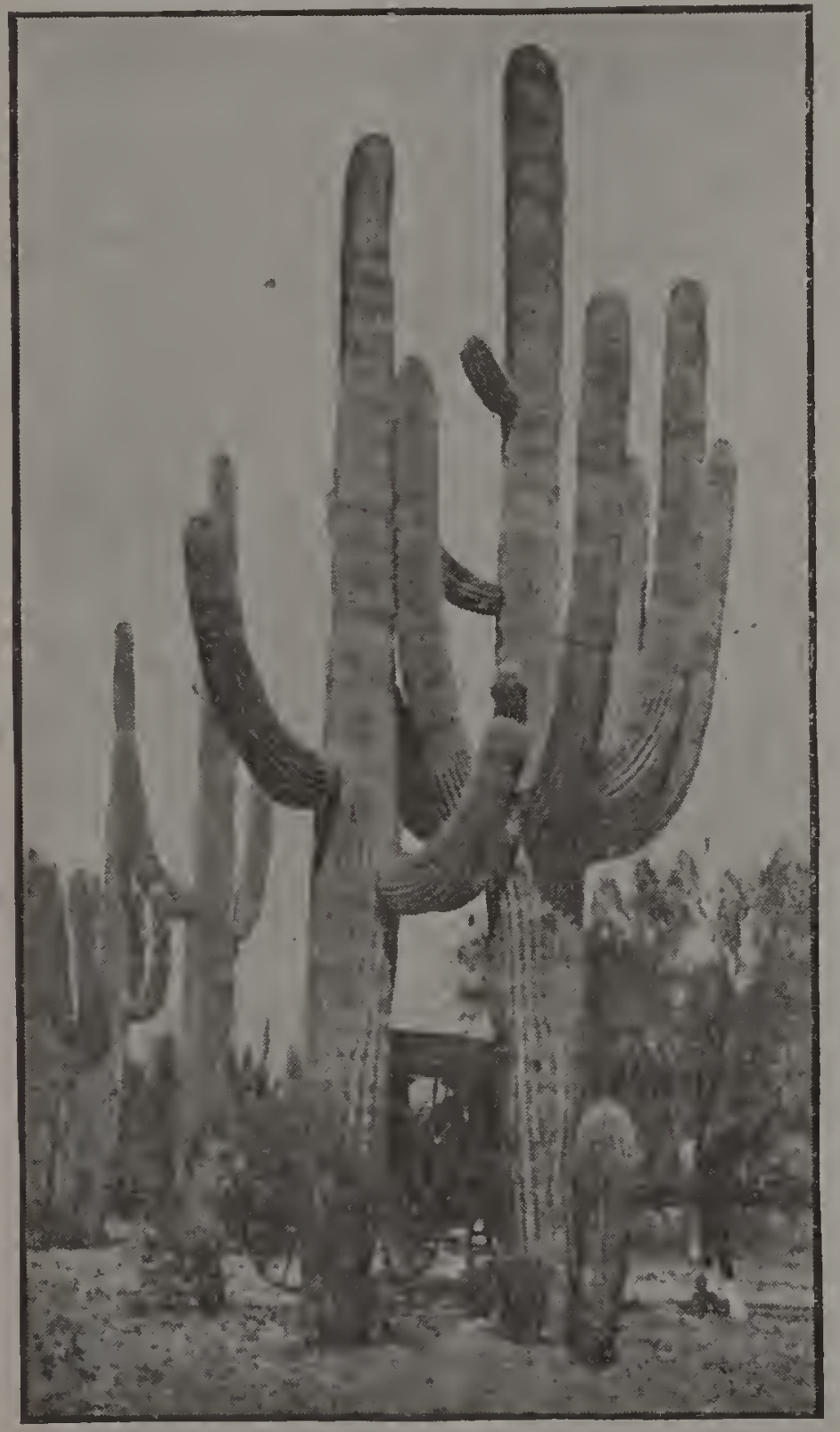

The saguaro

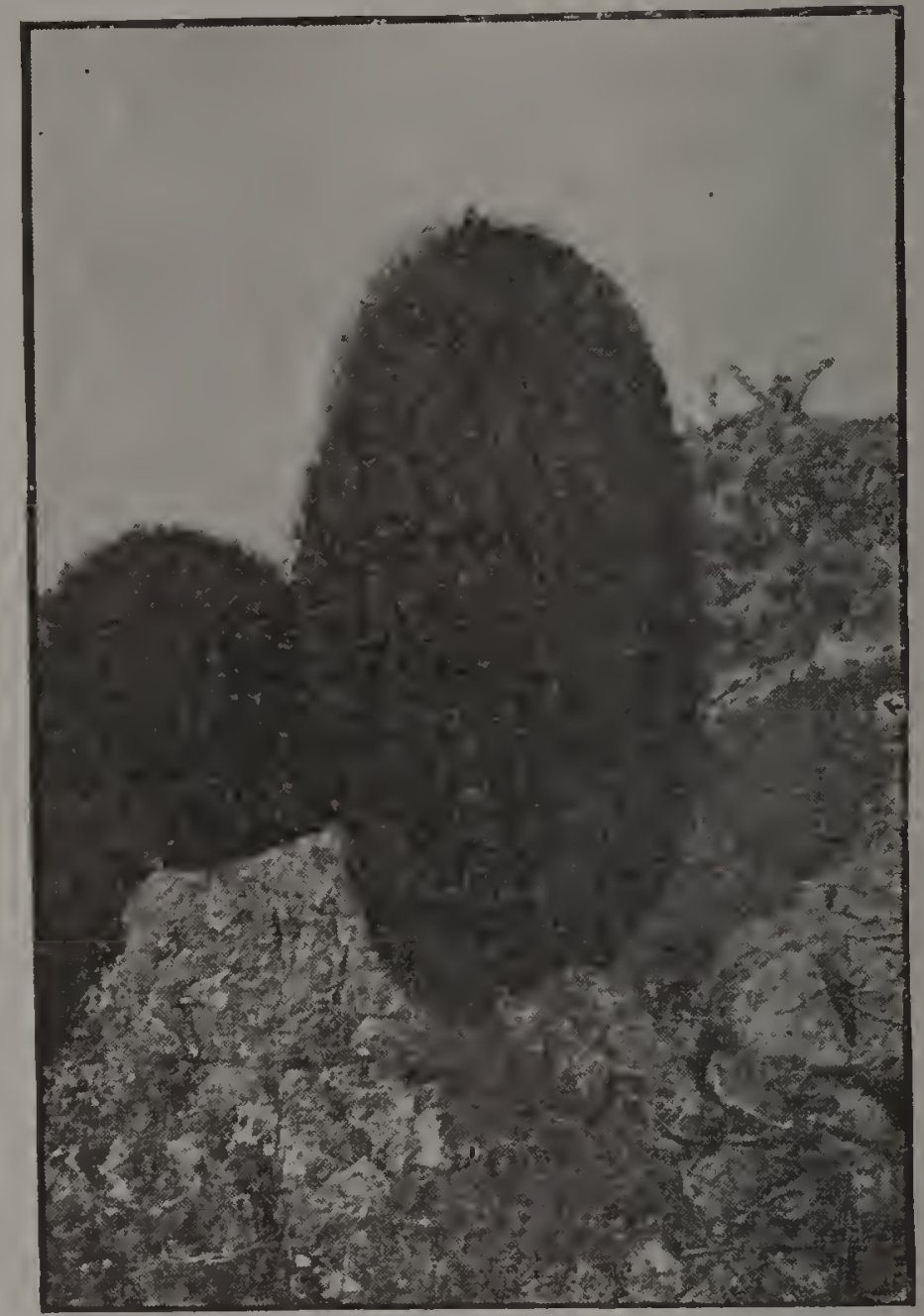

The barrel cactus

slopes of the mountains are what are commonly called the "mound cacti.", These vary in size from a few inches across to that of a bushel basket upturned. These are covered with thousands of sharp needles and have no particular beauty; but during blossom-time we are inclined to have a greater regard and admiration for them. These mounds are then covered with beautiful, delicate, waxy flowers. Some are bright red, while others are of a beautiful yellow. Surrounded by rocks, parched soil, and scrubby bunches of grass, these present a charming and spectacular appearance. They 
would naturally seem more fitting in our flower-garden, where rich soil, moisture, and sunshine give to the plants the beautiful green in their leaves and dainty colors in their blossoms.

The peculiar construction of the leaf-like branches and main stem of the cactus, generally, prevents any unnecessary loss of the scanty supply of water which reaches its tissues. This is what adapts it to the arid regions.

The amount of water found in a cactus on an arid plain is surprizing. A knife thrust into one behaves in about the same manner that it does when thrust into a watermelon. Then, too, the plant itself, after having the needles removed, was found to be valuable as a food for cattle.

The needles, or spines, being difficult to remove, made the cactus of very little use. However, the value of the cactus as food engaged the attention of Mr. Burbank, the well-known California naturalist, and by his untiring efforts in crossing he produced a cactus without spines. With the thorns gone and the fruit improved, the cactus bids fair to be an excellent food for cattle in dry regions. Thousands of acres of the spineless cactus are now cultivated for this purpose. Mr. Burbank has found five hundred kinds of cactus suitable for feed for stock, and some are also found to be valuable in food qualities for man.

-Wm. A. Bixler.

\section{A STUDY OF CENTIPEDES}

R ECFNTLY I read this statement: "Centipedes have nowhere a R good reputation." I began to wonder whether all centipedes were harmful and if even the poisonous ones had no qualities beneficial to man. I began at once to make a search for information concerning these creatures and their habits, and found them to be an interesting subject of study.

They vary in length from two or three inches in northern countries to a foot or more in the tropics. Their flattened body is made up of many segments, or joints, each of which bears one pair of legs. They do not, as the name would imply, have one hundred feet. Some species have as few as fifteen pairs, and the number of pairs rarely exceeds twenty-one. A peculiar characteristic of centipedes, we are told, is that 
they never have an even number of pairs of legs, but always an odd number.

Centipedes are active and ferocious. During the day they usually keep themselves hidden in dark damp places - under stones and bark, in decaying wood and leaves, or in loose soil. When night comes on, they go forth in search of food. They are flesh-eaters, feeding on worms, mollusks, and insects. As destroyers of insects they are of practical importance to agriculture.

The smaller forms seldom, if ever, bite man, but the large tropical species do and the bite is serious. The venom is injected into the flesh through a pair of modified legs situated close to the head and used to seize prey. The wound becomes red and swollen and exceedingly painful. The suffering has been described by those who have experienced it "as similar to what might be produced by" contact with red-hot iron." The swelling and pain, however, yield readily to an application of ammonia.

As a result of my study, I found that many centipedes are not only harmless, but really beneficial to man, and that I need not tremble at the name or be ready to end the life of every one I chance to see.

\section{HOW MISTLETOE AFFECTS ITS HOST}

THE time-honored mistletoe is not so imnocent, or free from harmful habit, as the whiteness of its berries might suggest. This plant, which for many centuries has been a very popular plant for decorations in winter-time, has fallen low under the denunciation of those who have investigated the conditions of the forests of Washington, Oregon, and Tdaho.

There are very many varieties of mistletoe, and it seems that, to some cxtent at least, each species has its preferred host and does not grow so readily upon other trees. For illustration: On a certain river in Idaho the lodgepole and yellow pines are heavily infected, and the larch is practically free from its attack. In another river valley not far away another species of mistletoe is found, and it works considerable injury to larches, while the yellow pine of this valley is not seriously attacked.

For some time the general and gradual decline of the western larch has been reported as occurring throughout the entire Blue Mountain 
region. Finally investigations were made, and it developed that the primary causes of the deterioration was due to the suppressing effects of mistletoc. On the drier and more exposed areas, where the conditions are less favorable for the host and more favorable for the parasite, the destruction is much greater than in the more moist and fertile valleys

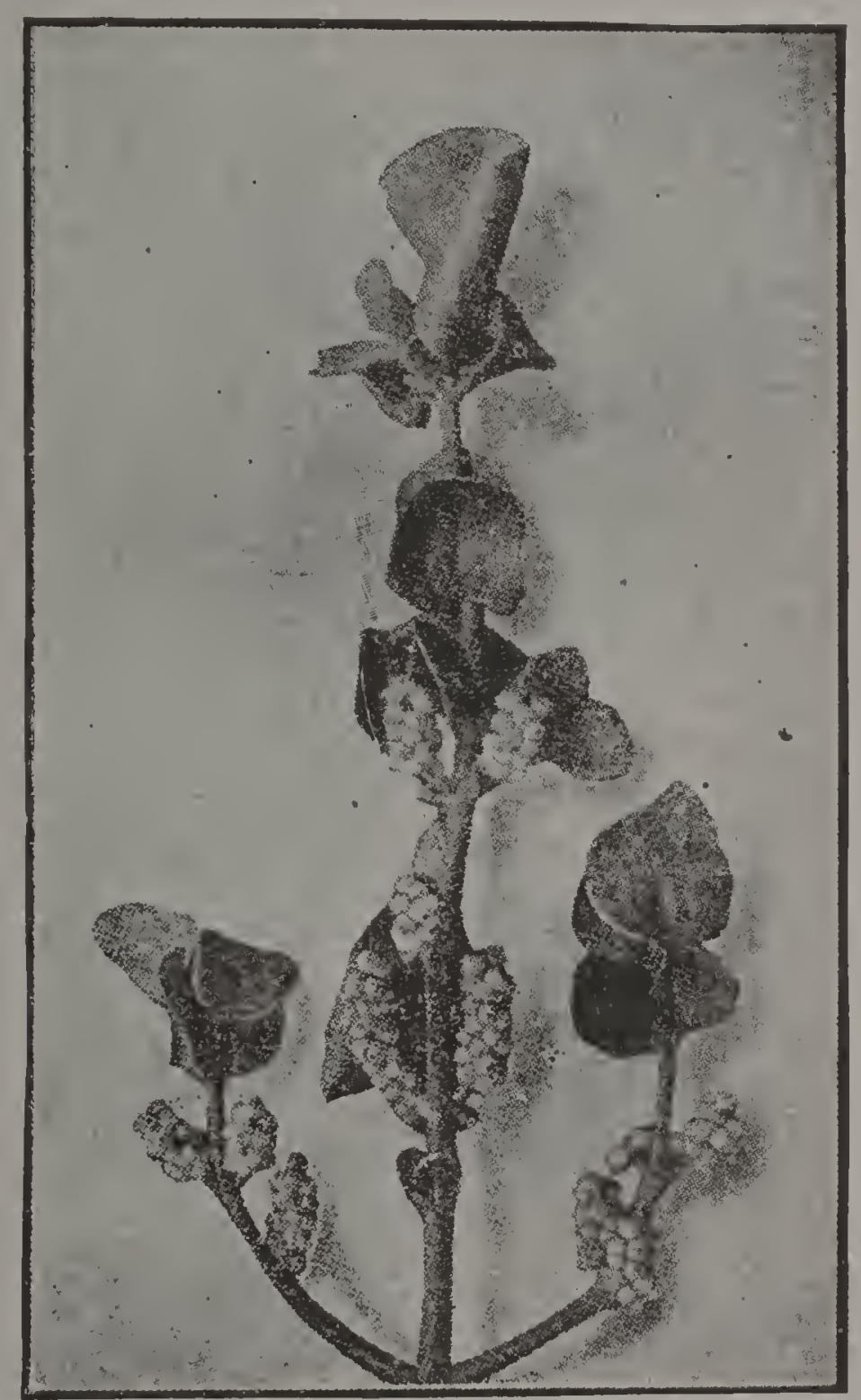

not parallel with the direction of the prevailing wind.

There are various ways in which the mistletoe injures its host, the tree on which it grows. It sends its roots through the bark into the growing layer and draws sustenance from the tree. As a result of this attack there grows upon the trunk or branch a burl which reduces the quality of the timber. When a young tree is attacked and these burls are formed, the food-transporting tissues are reduced and the glowth of the tree is directly hindered. Too, these knots often form open wounds for the entrance of fungi and insects.

But the mistletoe produces the greatest injury in the shortest time by causing the formation of witches'-brooms. Soon after a seed takes root upon a branch, the branch begins putting out from the point of infection many branchlets, which never attain much length. The cluster, or witches'-broom, grows larger and larger until finally the weight is too great for the parent branch to bear. So with a gust of wind a little stronger than usual the branch snaps and the witches'-broom falls to the ground. Oftentimes a tree is robbed of its foliage and branches in this manner and as a result of being thus deprived of its normal food-supply, dies at a premature age. Various suggestions have been made for the protection of our forests in the States mentioned above and for the destruction of the mistletoe. $-N$. Grace Graham. 


\section{POISONOUS PLANTS}

THERE are no beautiful poisonous flowers native to this country. 1 There are only three plants that are really poisonous to the touch. They all belong to the Rhus family, and resemble one another in their uninteresting clusters of dull greenish-gray berries.

Two of them, poison-ivy and poison-sumac, are found in the eastern part of the country, and poison-oak grows on the Pacific Coast.

Poison-ivy is a common vine that climbs over rocks and that in some shady places covers the ground with luxuriant leaves. Occasionally, in fertile spots, it will raise branches like shrubs up over the rocky supports; elsewhere it clings to the bark of trees and climbs high.

Its flowers and berries are always in dull clusters, but its leaves may become brilliant red and brown in the autumn sun. Do not pick leaves that grow in threes on a vine, but do not be afraid to gather the leaves of the woodbine, which grow in clusters of five.

It is difficult to distinguish poison-sumac from other sumacs. De not call it dogwood; it does not look like dogwood. True dogwoods have beautiful flowers, and are not poisonous. Poison-sumac grows like a small, branching tree; it is the cleanest and smoothest in leaf and branch of all the sumacs. The leaflets are long and pointed, five to eleven on one petiole. If you see little drooping clusters of greenish-white flowers, or later the greenish little berries, do not touch anything on that shrub or tree.

Poison-oak does not look like any oak. It has clusters of three almost round leaves, which grow on a vine like poison-ivy, or more often on a low shrub. If you see the clusters of white flowers, or berries, do not touch the plant.

There are many plants with sap that is more or less poisonous if it reaches a cut. Do not let a plant drip on a wound. There are many plants with thorns and stings that produce painful irritation if they scratch through the skin. Pick their flowers carefully.

Many beautiful flower's have sap that is more or less poisonous if swallowed. Do not ever hold flowers in your mouth. Do not give flowers to babies, for they are sure to put them into their mouths, and some of our familiar flower's have poison enough to affect a baby's health. 
There are other flowers and plants that are harmless to man, but poisonous to animals, if eaten. Many who read these lines know the bad effects of the loco-weed of the West or the lambkill of the East. In pastures where buttercups abound cattle carefully graze around them, but will not eat the flowers or leaves, because of the bitter taste of the poison in them.

The botanist and lover of flowers should remember two things: first, it is safe to pick any beautiful flower; second, it is never safe to let its juices touch the lips or any flesh wound.

\section{KATYDIDS}

$\mathrm{O}$ F ALL the shrubs and trees that grow, some tender-foliage tree like the willow will be selected by the katydids. In the year 1914 they delighted in munching leaves from shrubs on our lawn, and so far as I was able to discern, they made no attempt whatever to devour the foliage of any other plant, except a few basket-willows. Katydids are very modest and gentle. Their deep-green protective color makes it difficult to locate them on the foliage. At night the earth seems full of rasping noises of katydids; but when the sun comes up and chases the last bit of darkness off the face of the earth, the noise of the katydids ceases. When we go out to observe some of the noisy creatures, we become disgusted in the futile attempt. The trouble is we are likely to have a dozen katydids under our eyes and not distinguish their forms from the deep-green, leaves.

A number came to our basket-willow, and we tried to find them eating the foliage, but not until evening. On a number of nocturnal trips I found the katydids eating the foliage. I learned that when they are living on a tree the foliage of which makes good food, they rarely leave it. If our katydids ever left the basket willow, we were never able to make the discovery. At any time during the day or at night, we knew where to find them.

One night about eleven o'clock, just before I retired on a train, one flew and lit on the glass window on the outside. The bright light in the car shone out, and I was afforded a splendid opportunity for studying the insect. Immediately upon alighting it began to make its toilet. By rubbing saliva on its forelegs, it made a fairly good towel, 
and it rubbed every part of the body. It primped like some lady preparing to attend a social meeting. Despite the fact that our train was moving at the rate of forty miles an hour, it sat and clung to the smooth glass sash, and administered its evening ablution with apparent

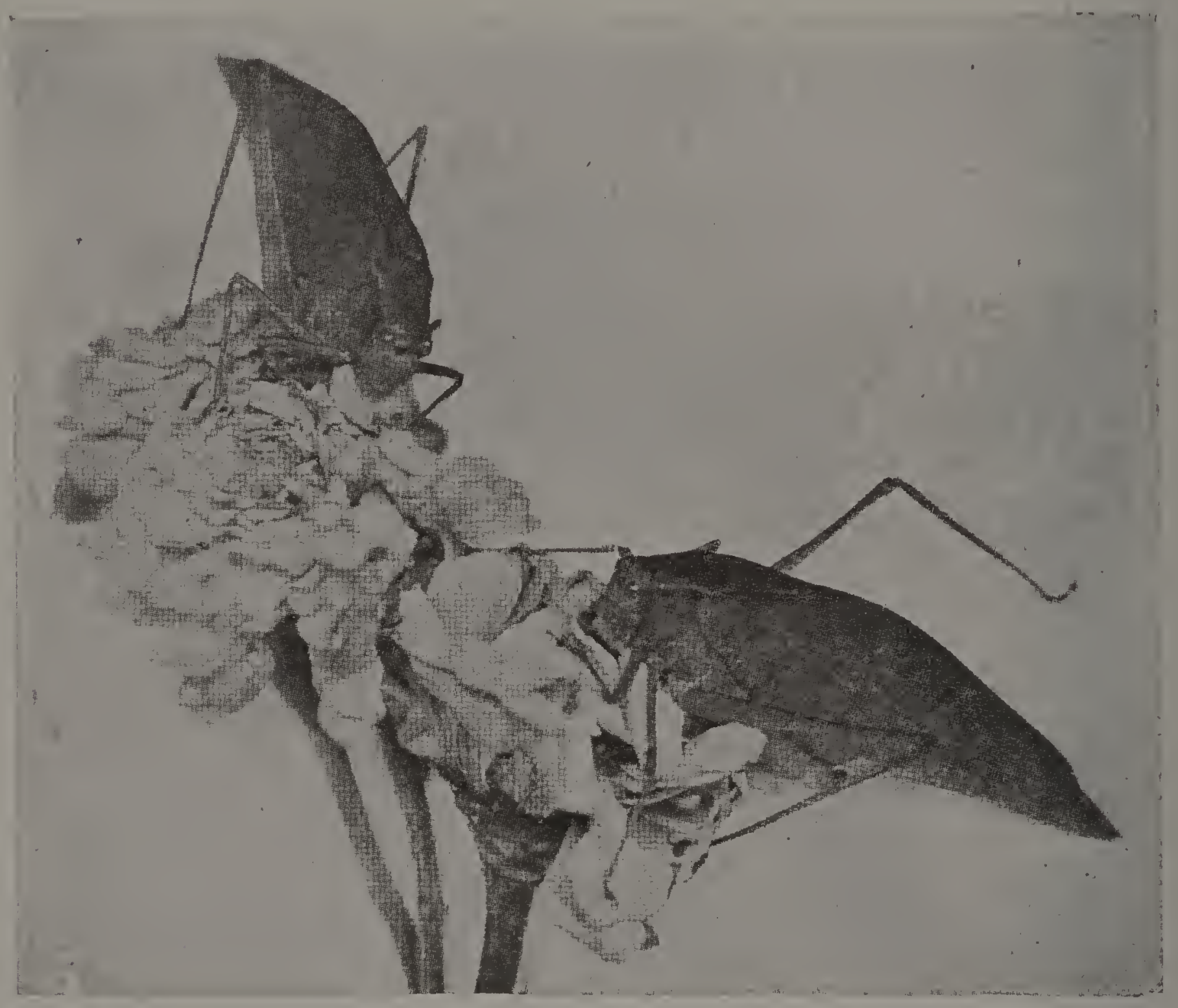

ease. When it was finished, it flew away. In the meantime it had been transported some fifteen or twenty miles. It was the first katydid that I ever had for a seat-companion in a Pulmani car, and before it left I learned to admire it.

Katydids belong to the grasshopper family. They sometimes make a noise in daytime, but this is rather weak and a very different one compared with the noise made at night. It makes the noise "katydid," by rubbing the overlapping wing-cover's against each other. This noise can be made even with the wings of a dead katydid. The eggs 
are flattened, oval in shape, slate colored, and are placed in a double overlapping row on twigs and leaves. One female will lay as many as 150 eggs in one season. These eggs hatch out the following spring. In the Southern States there are two generations each year. In the North they are single brooded.

$-N$. Grace Graham.

\section{THE MUD-DAUBER AND ITS WAYS}

THE wasps are indeed an interesting family. Being related to bees, 1 they are somewhat like bees in structure and habits. Some live in communities, having division, of labor somewhat similar to the community-bee; while others live solitary lives as do some bees.

Many of the solitary wasps display wonderful instinct in making their simple homes and providing food for their young. Since the mother wasp does all the work in providing a home and food for her children, it is little wonder that her young are not as tenderly fed and cared for as the young of those living in communities where there are many workers. Nevertheless, in a peculiar way, she provides well for her babies.

There are a great many kinds of solitary wasps, and they are distinguished largely by the kinds of homes they build. The muddauber and some others, all of which are sometimes called the masons, build their nests of mud. Another class, sometimes called the carpenters, bore holes in wood and the stems of twigs or even in straw. Still others, the miners, excavate holes in the ground as homes for the development of their young.

The mud-dauber is the best known of all these wasps, as it is very abundant in country places and builds its little mud nests in attics and outbuildings. Doubtless most of us are as familiar with its high-keyed buzzing sound as with its little mudhouse, for it keeps up a continual singing as it works.

If we could follow it as it leaves its nest for a load of material, we should see it light upon the muddy bank of a pond or a drain, perhaps, and go to work with all its might to chisel out a little pellet about the size of a sweet-pea seed. It is rather amusing to see one stand on its head with its tail straight up as, with its jaws, it completes the separation of the ball of mud from the bank. Then with the mud in its jaws, it flies away to add a little to the cell under construction. 
As soon as the cell is completed, the wasp catches a spider, deposits an egg on it and places both within the cell. It continues to catch spiders and place them in the cell until the cell is full; then with a ball of mud it closes the opening of the little cradle and, leaving the egg to take care of itself, goes to prepare another cell in a similar way.

After two or three days the egg latches into a little, white, legless grub. It begins at once to answer the demands of its ravenous appetite by devouring the spiders that are stored up in its cell. By the time these are eaten the grub is full-grown and ready to spin a little case for itself. In this case it changes into a pupa and remains until the transformation from the grub to an adult wasp is complete. Then, moistening the mud with the liquid from its mouth, it bites a hole in the end of its cell and comes forth the image of its parents.

If the eggs are laid early in the summer, the wasps hatch out and go to work at once to build nests and lay eggs. If, however, the eggs are laid in the fall, the pupæ lie all winter in the cells, not coming forth until the following spring.

The mother wasp dies soon after the eggs are laid. But if she is hatched out late in the season and does not lay her eggs, then she crawls into some safe crevice and lies dormant until spring.

As we look at the great things of nature, we are made to wonder at the mighty power of God, who created them; but as we study the many and peculiar habits and modes of life among the lower forms of animal life, we are impressed with the great wisdom of the Creator.

\section{INTERESTING NUTS ON TROPICAL SHORES}

SHOULD we be privileged to visit the islands of the south seas. one $S$ of the first things to attract our attention would be the waving coconut-palms. These trees tower upward to a height of about one hundred feet, and have slender, cylindrical stems about a foot in diameter. At the top they are crowned by a cluster of leaves, numbering from sixteen to twenty, which generally curve downward. The leaves measure from twelve to twenty feet in length, and have numerous leaflets two or three feet long.

The coconuts also grow near the top of the trees. They grow in clusters and when ripe fall to the ground or are pulled off by the natives. Fach nut is enclosed in a tough fibrous husk, which protects it 
from the attacks of insects. Sometimes the nut falls into the sea and is tossed by the waves until it reaches some distant shore. Washed ashore and buried in the sand, it grows into a tree. In this manner coconut groves have been started on low, sandy islands where very little vegetation is found.

The coconut affords a great portion of the food-supply for the inhabitants of the tropical coasts, one tree averaging from eighty to one hundred nuts annually. It has been the means of saving the lives of shipwrecked men who have been stranded on uninhabited islands. The nuts not only are eaten as they come from the trees, both ripe and unripe, but are also prepared in various ways, as in curries, etc. The milk of the coconut is simply the juice of the fruit, which, instead of being distributed all through the nut, as in soft fruits, is collected in the center. This the natives drink. The kernel of the coconut furnishes an oil which is used in manufacturing "stearin candles" and also a kind of soap called "marine soap," which forms a lather in salt water. The oil is also used for food.

The fiber of the husks is used in making coconut matting, also in making ropes, and is called coir. Taken from the ripe nuts, the husks are used for fuel. The shell is made into cups, goblets, ladles, etc., and is often finely polished and elaborately ornamented by carving.

Along the banks of the Orinoco and in the northern parts of Brazil, we find the beautiful trees on which Brazil-nuts grow. These nuts are sometimes called cream-nuts or nigger-toes. Have you ever wondered when eating them where they came from and how they grew? If you could visit their native shores, you would see them hanging far up in trees that reach a height of 100 to 120 feet. If ever you have thought that surely they do not have much of an outer covering for a protection, such as hickory-nuts and chestnuts have, you were badly mistaken; for though among the hardest nuts to crack, they have about the greatest outer protection of all. They grow from a flower as the apple grows. After the blossoms falls, a capsule forms, which grows larger and larger until it is almost the size of a man's head. Inside this shell are about twenty of these nuts, packed closely together like seeds. The capsule is very hard and heavy ; and when the nut is ripe, it falls down the high tree like a cannon-ball. The Indians will not go near a tree of this kind when the wind blows, lest the falling nuts should kill them. At the proper season the natives collect the shells and break 
them open. From Para alone more than fifty millions of these nuts, it is estimated, are exported annually, in addition to the large quantities which leave other Brazilian harbors. Besides being used as a food, the nut yields a fine oil, highy valued for cooking, and used by watchmakers and artists.

We marvel at the economy of God in creating fruits that can be useful in so many different ways.

\section{O LOVELY AUTUMN LEAVES}

O lovely, lovely autumn leaves!

What makes you fly away?

You make the earth so beautiful;

Why don't you always stay?

You don your very loveliest robes

Before you say good-by,

Then turning, leave usi all alone

To weep for you and sigh.

- The summer's roses all have gone,

But then we did not mind;

We knew you would be coming soon

On every autumn wind.

You fill the air with fragrance sweet

And carpet earth with cheer;

We can not have one thought of gloom

So long as you are here.

But when you fly, O autumn leaves!

Old Winter comes apace

And brings, unasked, a rug of snow

To shroud your cheery place.

O lovely, lovely autumn leaves!

What makes you fly away?

You make the heart so warm and glad;

Please, won't you always stay?

- Clara M. Brooks. 


\section{THE CALIFORNIA YUCCA}

IN the southwestern United States, Mexico, and Central America thrives a shrub, and sometimes a tree, known as the Yucca. Yucca is an Indian name erroneousy transferred to these plants from the

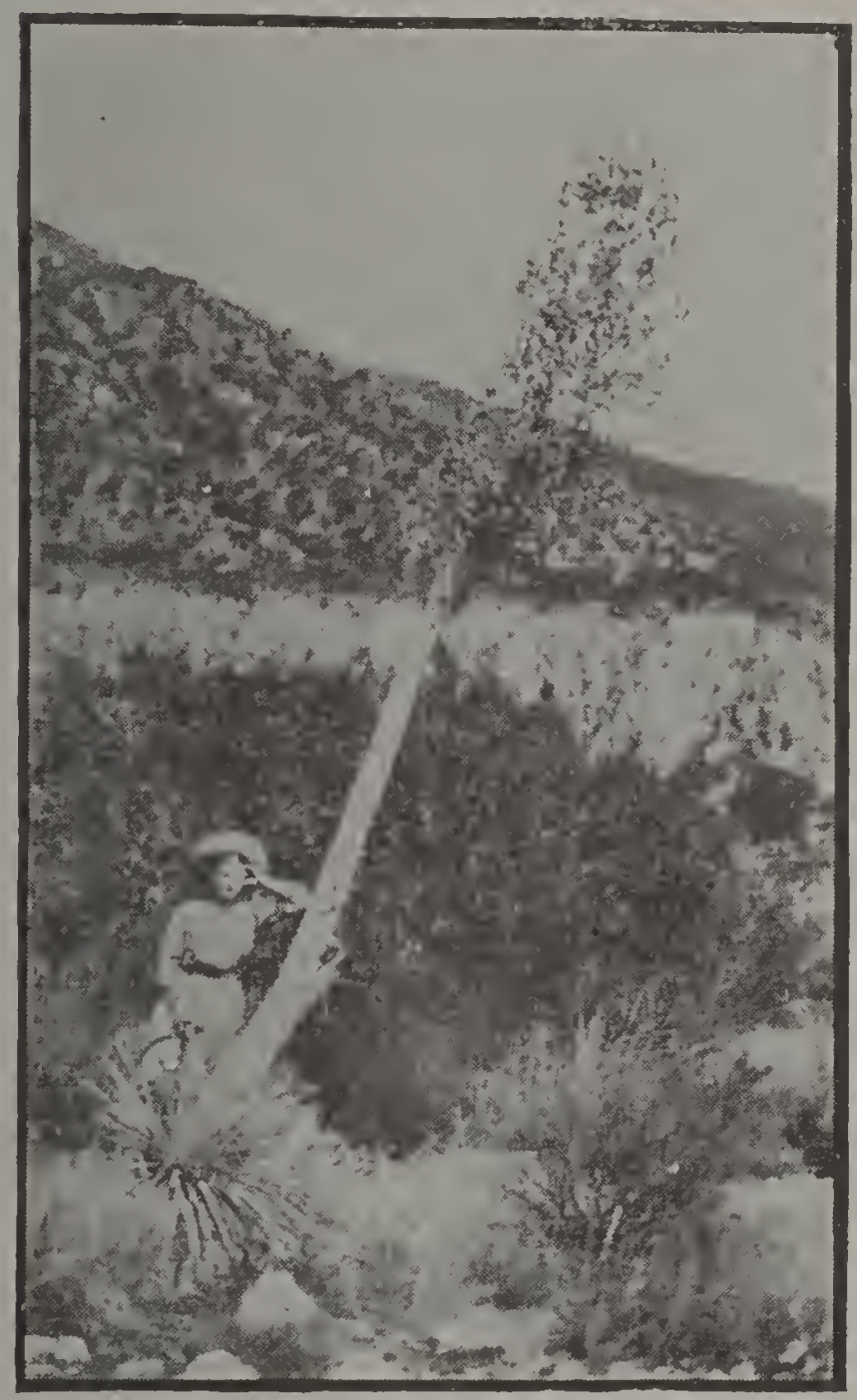

A yucca-plant in bloom manihot, a South American plant from the fleshy and starchy roots of which tapioca is made. Yucca was at one time one of the resources of the native tribes (Indians) of the deserts of California for fibers, it being manufactured into blankets, cards, mats, and baskets.

The yucca belongs to the lily family. There are about twenty different species, but we shall consider only the species known as Spanish bayonet. This plant is one that knows how to meet hard times; it can gather and store moisture enough to flourish in the deserts. It makes and stores so much food that, when the right season comes, usually in May, there shoots up in a few days a stem ten or fifteen feet high, bearing one of the most beautiful flower-clusters I have ever seen.

In the accompanying picture you will notice the enormous size of this plant and perhaps wonder at its being called a plant of the lily family. This yucca is an unusually large one. It measures about twenty feet in height and about ten inches in diameter at the base. At the summit the flowers run up in the form of a pinnacle for about eight feet. At the base are large dagger-like leaves about three feet long and six inches wide. These bayonetshaped leaves taper to the apex, from which projects a large thorn. The leaves can defend themselves so well that this species of yucca has been called Spanish bayonet, and I assure you that the stabs which this one gave me when I approached its base were not at all pleasant After this plant matures, the stem that shot up so rapidly in the 
spring, becomes dry and of a brownish color. Where the white fragrant blossoms were are the round, oblong seed-pods. The trunk consists of a soft, spongy substance (pith) covered with about an eighth of an inch of hard shell; consequently it is very light. When about nine feet of the trunk of this plant was cut off, my two little nephews could easily carry it on their shoulders.

One very interesting fact about the rucea is that it depends for the most important thing of all-its seed-production-on a tiny moth no longer than your finger-nail. Since the plant keeps its anthers, on which the pollen grows, away from its stigma, it renders the flowers incapable of self-pollination. The moth herself does not need food, but she knows that when her eggs hatch, her little larva will be very hungry and that the only food they can live on is the yucca-seed. But she seems to know something much more wonderful than this - that the yucca will not produce seed unless the pollen reaches the stigma. At any rate, she acts as if she knew. This is what she does: Before laying' her eggs she gathers a mass of pollen larger than her own head; next she lays her eggs in the ovary of the flower; and then she immediately crams the pollen down the concave stigma of this flower. So the big yucea can trust to the mother instinct of this tiny creature. True, her babies eat part of the seeds, but there are quite enough left to keep up the supply of yucca-plants.

This picture was taken from a large yucea that grew in Pacoima Canyon, about twenty miles from Los Angeles.

- Annabel Lee IInnex.

\section{INTERESTING FACTS ABOUT NUTS}

A MONG the many nuts that come pattering to the earth in autumn, A we find walnuts, chestnuts, hazelnuts, butternuts, hickory-nuts, and pecans.

The name "walnut" means foreign nut, so called because the nut was first brought from Italy and France. There are about ten species of this nut, but we are most familiar with the persian, or English, walnut and the black, or common, American walnut. The English walnut is cultivated extensively in southern California. The tree grows to a height of sixty to ninety feet, and has large, spreading branches. The 
leaves have a fragrant odor when bruised. The tree contains a sugary sap and is sometimes tapped like the sugar-maple. The unripe nuts are sometimes put in vinegar and converted into pickles. In the Old World the walnut is an important food for the poor people. The black walnut is found in most parts of the United States except in the extreme northern. It grows on one of the most beautiful trees of the American forest. The nut has a thick, woody shell, and is inferior to the English walnut.

The chestnut is native in most of the Eastern States. There are a number of dwarf forms, known as chinkapins, which are quite common in the States south and east of Pennsylvania. These small nuts are edible, and are marketed to some extent. The chestnuts grow in prickly burs, usually three nuts in a bur, packed closely side by side. After a frost these burs break open, and then the nuts may be easily obtained. In Europe chestnuts are steamed and eaten either with salt or with milk. They are also boiled like potatoes by the poor people, or roasted, or ground into flour, from which bread is made.

Two species of the hazelnut are native to the United States-the American hazel, and the beaked, or California, hazel; but neither of these is cultivated. Most of the cultivated varieties are known as cobnuts and filberts. These nuts yield an excellent oil, which is used in painting pictures and also in making costly perfumes.

The butternut is so called on account of its oil, which is sometimes extracted. When the nuts are dried, they form agreeable food, and when taken green and picked, they are prized for the table. Sugar can be made from the sap of the tree, but it is much inferior to maple-sugar. A dyestuff was formerly prepared from the bark and husks, and was widely used for dyeing woolens, etc. It was sometimes resorted to by the early settler's in the United States to dye their homespun clothing.

The hickory-nut and the pecan belong to the same genus of trees, the pecan being a species of the hickory. These trees are strictly North American. The nuts of some of the species have an excellent flavor. The pecans are grown for the market in some parts of the United States. The varieties called paper-shells are the most desirable as they can be cracked between the fingers and easily separated from the shell.

The meat of the nuts contains about fifty times as much fat as wheat flour, and has about double the fuel value, or energy producing 
power; but is lacking in other essentials to make it as healthful a form of food. There is a popular belief that a little salt eaten with nuts aids in the digestion, but no investigations have found this to be true.

When we know of the various ways in which our common nuts are used, we are made to appreciate more the goodness of God in giving them to mankind.

- Eskell L. Blore.

\section{BANANAS IN TRINIDAD}

WHEN Americans who have just come to Trinidad hear a woman carrying something on her head ery out, "Get your figs, ladiesfigs, figs, figs," they at once think they will get some figs. But when they go out to buy, they find that what the peddler called figs are bana-

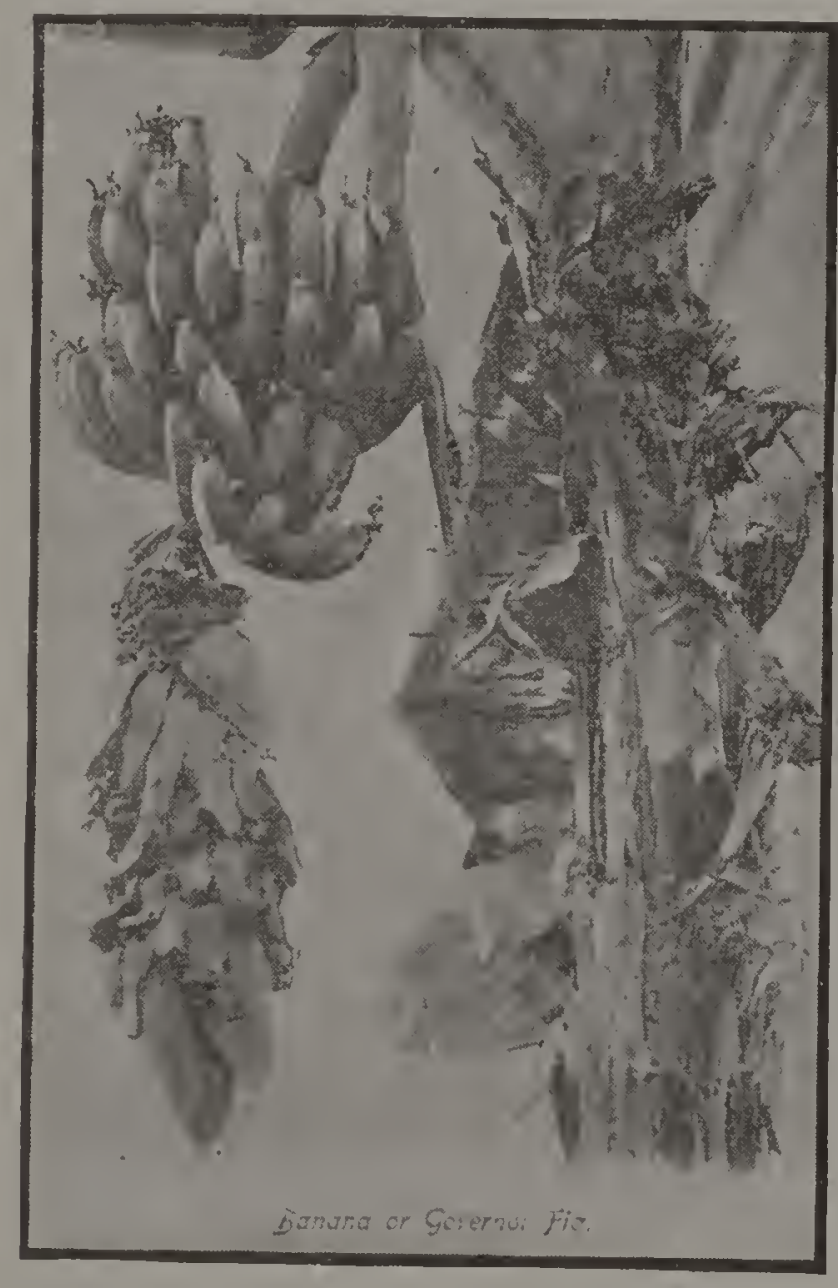
nas. I do not know how it ever came about that the people here should call bananas figs, but that is what they call them.

The banana ranks first among the tropical fruits. It bears fruit the year round; that is, at any time you can go to a banana-plantation and gather ripe fruit. This is not so with many other fruits. The banana-plant has a perennial root, that is, the root lives for years; but the sprouts are short-lived. Young plants are obtained by cutting sprouts loose from the parent root when they have grown to the height of three feet. These are set in rows from eight to twelve feet apart.

The banana begins to bloom in one and a half or two years after it has been established. Wach stalk bears a bunch of from fifty to one hundred and fifty bananas. A stalk bear's only once. After bringing its fruit to maturity it dies down and is replaced by new sprouts from the root.

Bananas are very nutritious, and, in general, they have no bad effects on the system. Most varieties can be eaten at any time of the 
day, while fruits that contain much acid are not eaten by the people here when warm from exercise. There is one variety of the banana, however, that many people here are afraid of when heated from exertion. I do not know the name of this particular one, but it is red and much larger in circumference, though shorter, than "the Governor"s" banana. The flesh is more solid and has a different taste from other bananas.

Then there are two varieties that are very small. I believe they call one the silk fig. They grow to a length of from three to five inches and are only about six or seven eights of an inch in diameter. The skin on these is very thin and does not lie in sections as does the skin of the larger kinds.

We scarcely buy any figs (bananas). The people frequently send us some, and once in a while some one will send us a whole bunch, perhaps more than a hundred. We hang them up as people do in the stores, and eat them as they ripen. Bananas are gathered before they are ripe. The bunches are so heavy and the bananas so soft when ripe that many would be mashed and ruined; for when once a banana is bruised it very soon begins to decay and if eaten then in a tropical climate may induce dysentery or some other disease.

- E. N. Reedy.

\section{THE MANGO AND OTHER TROPICAL FRUITS}

WO other tropical fruit, to my knowledge, grows so plentifully as flavor, but because of a kind of tough string that grows around the seed and makes the eating rather an unpleasant job. One can scarcely eat a mango without getting more or less of the soft yellow substance smeared about on hands and face.

There are many varieties of the mango. The trees grow to a height of forty feet and bear well. The foliage is dense, producing a welcome shade. All parts of the tree have a turpentine odor, and even the fruit of some varieties have a flavor of turpentine. Other varieties, however, highly prized for desserts, are luscious, sweet or slightly acid. The unripe fruits are used for pickles, sauces, etc.

I will describe a few of the varieties. Mango calabache (see cut) is about the largest variety. It does not get yellow, but remains green. It has fewer strings than the others, but has a poorer flavor. The 
mango ve is a beautiful fruit, has a good flavor, but has many strings. The mango-steen is about the best.

Trinidad abounds in fruits, but an American is put to some brainexercise trying to remember some of the names. We have a large bean here that grows on a large tree. The pod may grow to be seven inches long, and contains a number of beans. The beans are so hard that they

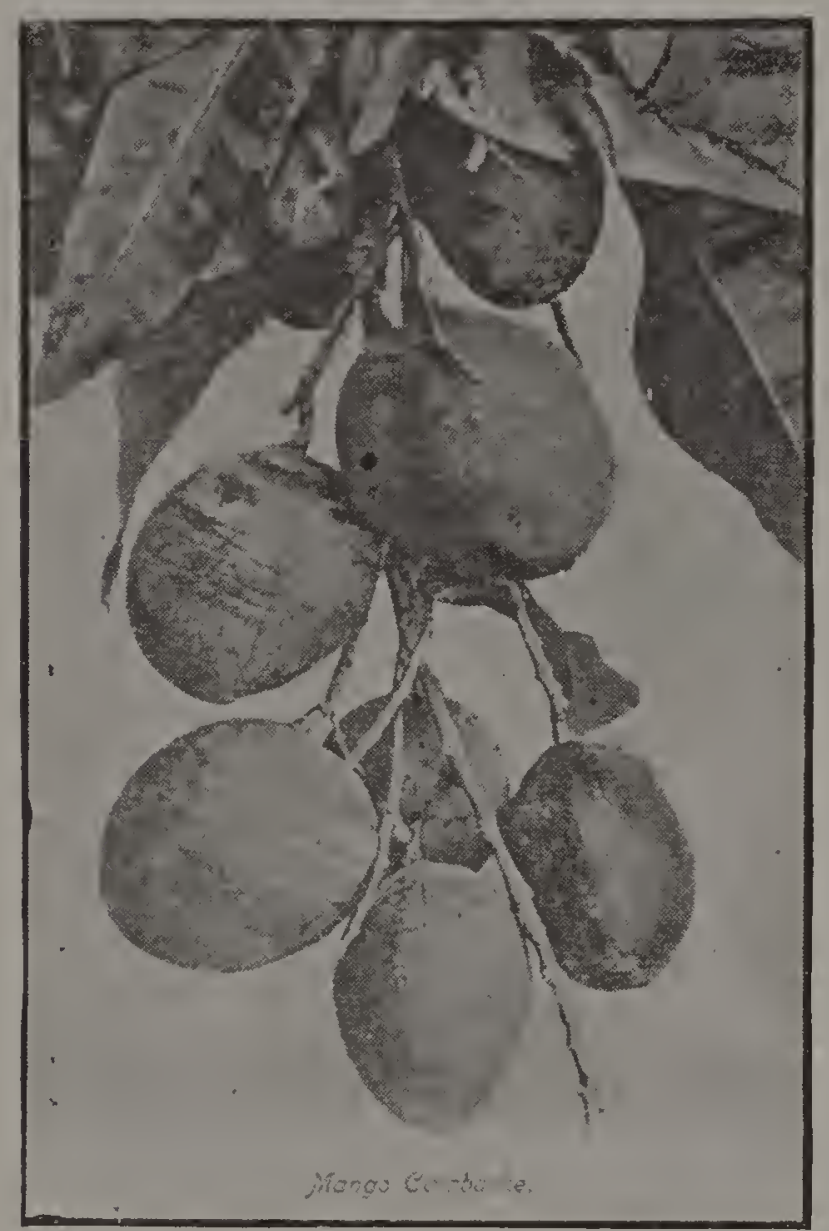
can not be eaten, but around them is a coat of jelly-like substance that is exceedingly sour. The natives take this and sugar and make a very savory dish. There is also a long round black bean that looks like a stick of licorice and tastes very much like licorice. The licorice-like material lies in little layers inside the shell.

Another tropical fruit not much spoken of is the chennet, a pleasant little round fruit growing in abundance on large trees. The skin is a crust-like substance easily broken and pealed off. The only flesh it has is a little jelly-like substance sticking tight around a big seed. One puts the whole thing in his mouth and sucks off the jelly. When one gets a dozen big seeds piled up, he has not eaten more jelly than a medium-sized spoon would contain. So chennets are not worth much, which is true of many other tropical fruits. $-E$. N. Reedy.

\section{OUT-OF-DOORS ARITHMETIC}

Add bright buds, and sun, and flowers,

New green leaves and fitful showers,

To a bare world, and the sum

Of the whole to "Spring" will come.

Multiply these leaves by more, And the flowers by a score; 
The result, if found aright,

Will be "Summer," long" and bright.

Then divide the flowers and sum

By gray clouds and storms begun,

And the quotient found will be

"Autumn" over land and sea.

From this then subtract the red

Of the leaves up overhead,

Also every flower in sight,

And you've "Winter," cold and white.

-Selected.

\section{BEETLES}

THF teacher had been telling her pupils about insect-life, and she 1 asked if any of the boys could find some of those large white worms sometimes used as fish bait and called grubs. Some of the boys thought they knew where they could find some and were soon away with shovel and can hunting for the grubs and wondering what use their teacher would make of them. Finally the boys returned with several grub-worms. These they placed in some damp earth from the woods, according to the teacher's suggestions.

In a few months the pupils were all surprized to see several .Tunebugs crawl from the earth and go buzzing about the room. They searched the earth, but found no grubs; instead they saw only the empty skins.

The June-bug belongs to the beetle family of insects. When resting, beetles appear to be wingless, but they really possess two pair of wings. One pair, which is very delicate, lies folded snugly under the other pair, the two parts of which, meeting along a line in the central part of the back, form a hard case, or covering. This thick, heavy pair of wings protects not only the gauzy wings but also the soft body.

Beetles live under the greatest variety of conditions and are found in nearly all parts of the world. They live not only on dry land, under rocks, and in caves, but in both salt and fresh water as well, and a few breed in hot springs. 
The food of beetles and their young is as varied as their habits. Many of them feed on vegetable matter, both living and dead; other species live on animal food, which they capture alive; while still others show a fondness for decaying matter. Thus, in their habits of feeding some are very helpful to man; but, taken as a whole, they are considered as being economically injurious.

They have many enemies, as birds, reptiles, rodents, frogs, and toads. These prey upon the beetle in both the adult and the larval stage.

In their life cycle, beetles undergo a complete metamorphosis, one quite similar to that in the development of butterflies and moths. The eggs are laid in such situations as will afford food for the young larvæ, or grubs, as they are generally called, when they are hatched. The pupæ of some species are enclosed in cocoons, or cases; others pass this stage in burrows in wood, and still other's beneath the surface of the ground. There are various other modes of preparation for the pupal stage, which usnally lasts only a few weeks or months, but in some cases years.

\section{HOME LIFE IN AN ANT COLONY}

A NTS are close relatives of wasps and bees. Not only is their A structure similar, but also their instincts and modes of governing their societies. Bees have two forms of the female sex-the well deveioped ones, or queens, and the imperfect ones, or workers. In the ant colony there are (1) the well developed females, which produce the eggs and thereby propagate the species; (2) the smaller imperfect femnles, or workers, some of which gather food, while others nurse the young; (3) the larger imperfect females, which act as soldiers to protect the ranks of foraging workers.

Usually the males and the perfect females have wings, and the workers are wingless; but exceptions to this are not uncommon. Queen ants are more peaceable than queen bees, and more than one queen ant may, without quarrels, live in a single colony.

When the winged males and females, emerging from their pupæcases, make their appearance in the ant colony, they are guarded by the workers until a suitable time for flight. Finally, on the warm days of summer and autumn they are permitted to go into the air where 
they appear in myriads. Mating nearly always takes place while they are on the wing.

Soon after mating, the males die, and those females that escape their" enemies settle to the ground, tear off their wings, and make excavations in materials suitable for the construction of their nest. The eggs are then laid, and when the larvæ are hatched, they are fed on some substance already stored up within the body of the queen-since she never goes out for food.

When the workers of the first set, which are of small size, appear, the care of the larvæ and pupæ is left to them; and thereafter the queen devotes her'self exclusively to egg-laving. Thus a new colony is established.

The workers appear to be very affectionate toward their queen. They feed her and follow her on her wanderings throughout the passages and chambers. When in her presence they not infrequently perform the same peculiar antics and capers that they employ to express their emotion upon the return of a lost comrade.

As the queen produces the eggs, the workers carry them to suitable locations. In caring for the legless larvæ and pupæ, the workers carry them to the surface layer's by day, for the sake of the sun's warmth, and at night or during rain to deeper and drier chambers.

The larvæ are fed from the mouths of the nurses, upon a liquid secreted or elaborated for this purpose. These nurses carefully lick and rub the larvæ to keep them clean, and when the time arrives for the adults to emerge from the pupæ-cases, the workers are at hand to help them out and unfold and dry their wings and legs. Then the workers must perform the duty of guarding the winged members of the colony until a suitable time for them to take their flight.

The nests, or homes, of ants are very different from those of their relatives, the bees and wasps. Instead of building their homes of wax or papery pulp, as these latter insects do, ants burrow into the ground or into rotting or living trees, shrubs, or herbs. Bees and wasps divide their nests into even compartments, or cells; and in each cell one egg is laid and one individual is reared. The ant's nest is made up of a variable number of chambers of irregular shape, connected by galleries; and the young of ants are kept in heaps and moved around from one part of the nest to another, as conditions of temperature and moisture demand. 
The chambers and galleries excavated into the earth extend a considerable distance down to the region of constant moisture. Some ants of South America are said to cross wide river's by tunneling under the river-beds. Sometimes the nest is carried above ground by means of earth heaped up and often cemented together. In South America ant-hills often exceed the height of a man. I recently saw a picture of an ant-hill in Africa, the top of which was crowned with a dwelling for man. Such ant-hills are from twenty to thirty feet in height and have. been used as look-out stations on the Cape-to Cairo Railroad.

\section{THE PITCHER-PLANT}

I various parts of the earth grows a peculiar plant called the pitcher1 plant. The one shown in the picture grew in Jamaica, one of the islands of the West Indies. This plant generally grows in swampy

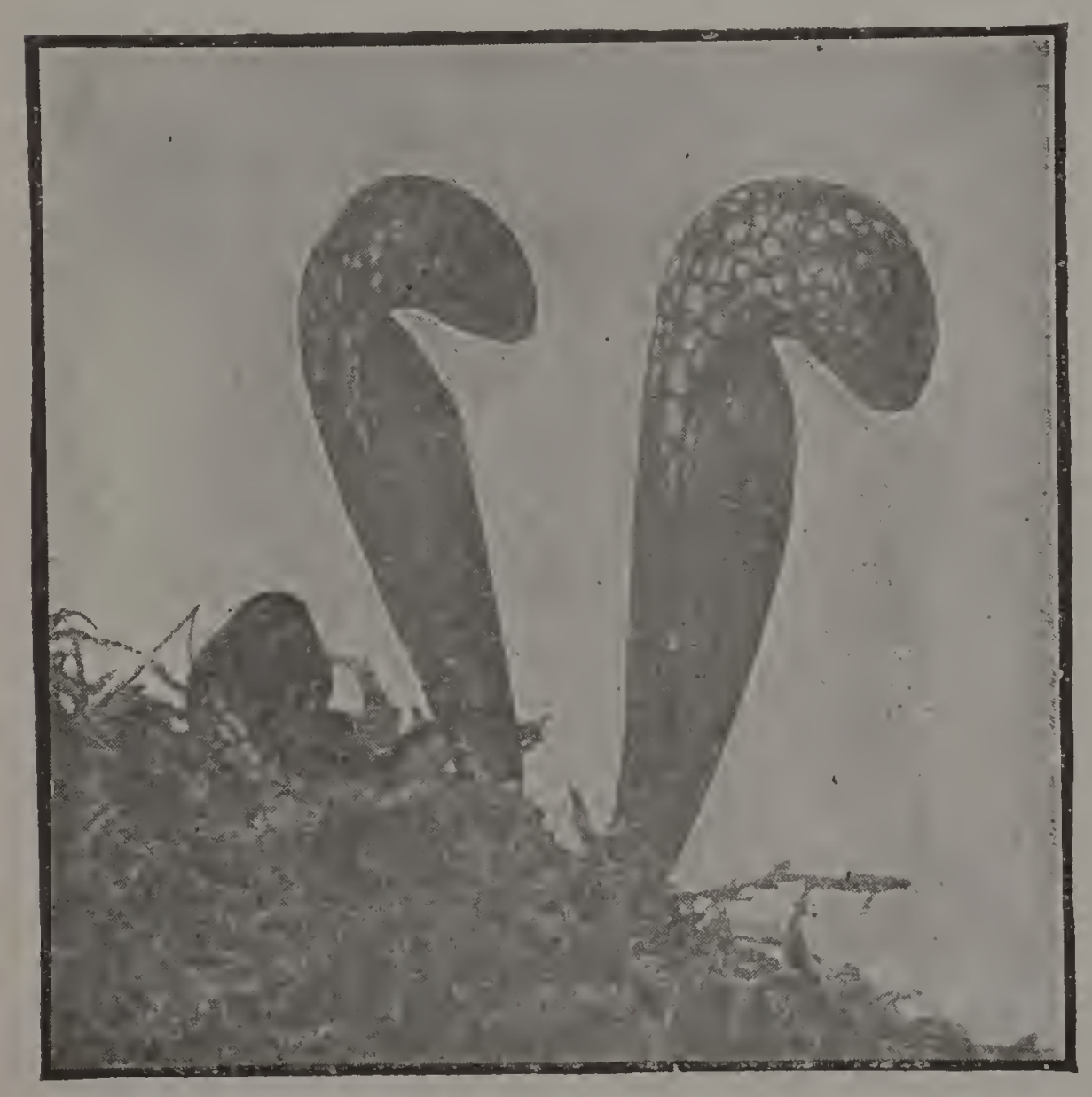

The pitcher-plant places, probably on account of its need of abundance of water. The leaves are long and hollow, and the upper part forms somewhat of a cap, which opens and allows rain-water to collect in the leaf pitcher below.

Insects of all kinds (and they are very numerous in tropical climates like that of Jamaica) crawl down the inner surface of the pitcher, but are prevented from escaping by the hairs that line the inside of the leaf and point downward. As a result the pitcher collects many insects, which nature has caused the plant to utilize as food. In this way it thrives in soil which is naturally poor in nitrogen. 
The photograph from which this picture was made was taken on the side of the leaves that do not show the opening at the top, but the top of the leaf folds over so neatly that a person not accustomed to the nature of the plant would pass it by as a common leaf. Those who are acquainted with the flower jack-in-the-pulpit will recognize something of a similarity in the way the upper portion, or lid, folds over the lower part.

\section{THE MILLETS THAT HELP FEED THE WORLD}

MEMBERS of the vegetable kingdom as well as members of the animal kingdom are grouped into families. The millets form a very interesting family. They are a relative of the grasses. Their family is a very old one; for their ancestry can be traced back to the Stone Age, a period when men had not yet learned how to make implements of metal with which to cultivate. They do not thrive well in heavy clay or wet soils, but prefer living in a crumbly loam. In the old countries millions of bushels are ground every year for bread or mush.

The three chief members of this family are foxtail millet, broomcorn millet, and barn-yard millet. Foxtail millet with its long, fat, bushy head seems to be the most important. It is a native of China, Japan, and the Indian Archipelago, and is said to have been found in China more than two thousand years before Christ.

Barn-yard millet is grown largely for hay. It furnishes a useful coarse fodder, and when raised for hay is harvested with a mower when the crop has just finished heading. If it is raised for the seeds, harvesting takes place a short time before the grain has fully ripened.

Broom-corn millet is perhaps the most widely known. It is probably a native of warmer Asia. We sweep our floors every day with its straws that have been made into brooms. In the United States, Italy, France, and Germany it is cultivated solely for this purpose. But in India, China, and parts of Africa it is cultivated for various purposes. It is cultivated in the Himalayas in altitudes up to 11,000 feet. It thrives on the dry uplands of central Asia, when the durum wheats and other grains are a failure. In Crimea it furnishes food for the Tartars, and has been found to be one of the best grains for poultry. It is a great food staple of the Kirghiz tent-dwellers in the desert. They thresh it by pounding a sack of it with a stick and then winnowing it in the wind. 
The millets are valuable, not only because of their hardy qualities and their food values, but because of the fact that they can be sown late in the spring and still be harvested without interfering with the harvest of other cereals. The seed is usually sown broadcast, though sometimes drilled.

- Eskell L. Blore.

\section{THE POMEGRANATE}

THE name "pomegranate" is known to most children. Those who 1 are familiar with Bible stories have heard of it. Others have read of it in Greek or Roman myths or other stories of ancient times. But

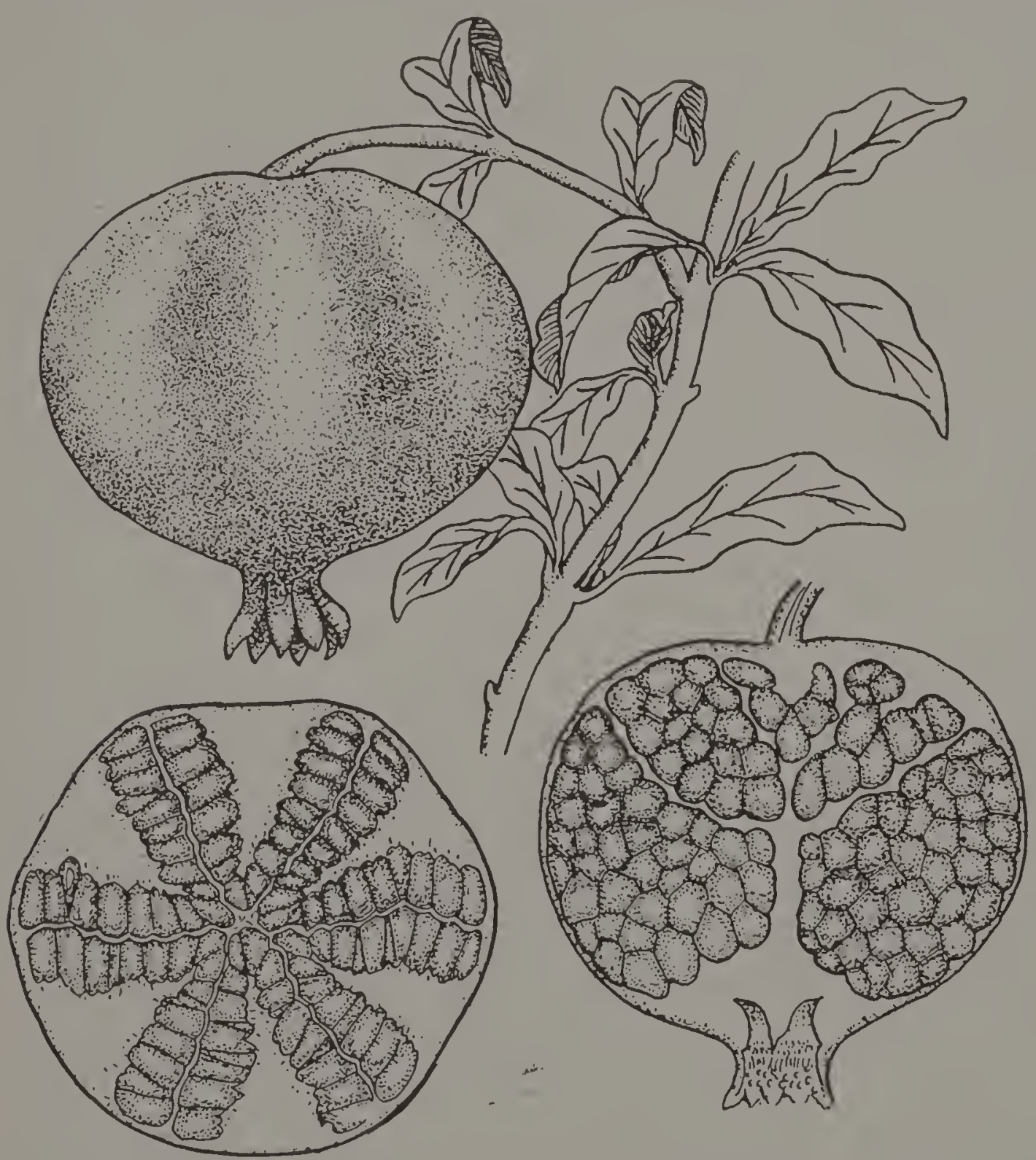

perhaps few of our readers have ever seen a pomegranate.

In the picture we have three views of a pomegranate. One shows the general contour and the position on the stem, also the opposite lance-shaped leaves; the transverse section shows somewhat of the arrangement of the seeds in the lower half of the fruit; and the longitudinal section gives an idea of the arrangement of the double rows of carpels, which shall be spoken of later.

The shrub, or small tree, on which this fruit grows is a native of southwestern Asia. According to some historians, it was cultivated throughout that country for more than a thousand years before Christ. 
It is extensively grown in southern Europe, and may be seen in parts of America. The tree is very tender, being injured by a temperature of eight to ten degrees below freezing. In the United States its cultivation is limited to the southern part of Florida and the warmer parts of California.

The flowers consist of a thick fleshy cylindrical or bell-shaped calyxtube, with five to seven scarlet or crimson petals, and below them very numerous slender stamens, or pollen-bearing parts. The pistil is unlike those usually found in oranges, which have one row of carpels, or seed apartments. In the pomegranate it has two rows of carpels, one above the other. Fach carpel contains numerous seeds which are partly embedded in the inner surface of the calyx-tube.

Each fruit usually attains the size of an orange. As it develops from the flower, the calyx-tube becomes enlarged and its wall forms the leathery rind, which is generally yellow with a rosy cheek.

Tn some places the plant is used for hedges. Also ornamental varieties with double flowers are grown. A kind of pomegranate producing fruit without seeds is cultivated in India and in Persia. The people highly prize this kind. The rind, the bark, and the outer parts of the root are valuable on account of the large quantity of tannin they contain. It is said that the finest morocco leather is tanned with the rind of the pomegranate.

The most valuable product of the tree is the coat of sweet or" mildly acid pulp, which encloses each, of the many seeds in a separate apartment. The juice from the pulp is largely used to make cooling drinks.

\section{PECULIAR HABITS OF CERTAIN SPECIES OF ANTS}

I COLORADO, Arizona, New Mexico, and Mexico, live several 1 species of ants known as the honey-making, ants. Like other ants, they live in colonies, in underground nests.

The foraging workers obtain the honey at night from small galls on oak-leaves. After the other workers and the young are fed, the honey that "is left over is communicated to a number of ants which simply serve as living receptacles. These live honey-bags cling to the roof of the nest-chamber and move very little, and in time their 
abdomens become enormously distended." According to the naturalist McCook, "these living storehouses merely retain the honey until it is needed by the colony during the, winter, when it is given out from the surcharged crops to feed the colony."

In West Africa are found the driver-ants, which grow to be nearly half an inch long. Though blind, they go about, mainly at night, in large "armies" that kill all the smaller creatures overtaken. When they enter a village, the negroes are obliged to leave their houses as long as the ants remain. But when the ants are gone, so are all rats, mice, lizards, cockroaches, and other vermin; for the ants catch, kill, and devour all these that fail to flee out of their way.

The driver ants are said to have no fixed abode, but to move about from one place to another, crossing rivers by clinging to one another in a living chain, or bridge, over which the others pass. When disturbed by floods they form into spherical masses and float until they drift ashore. When, in an overland journey, they are about to cross a well-trodden path where they are likely to be disturbed, the soldier's cling together and form themselves into an arch, extending across the whole width of the path. Under the protection of this arch the perfect females and the workers bearing the larvæ pass without the least exposure. So tightly do the soldiers cling together that they have been lifted, by means of a cane placed under the arch, as high as five feet above the ground without a single ant's falling.

The foraging ants, also called army-ants, which are found in Central America, have some interesting habits. They go about in large bodies making raids upon insects and other small animals. As they march forward in columns three or four yards wide, including many thousands of individuals, larger animals flee from before them. Insects try to leap away, but more often jump into the midst of the ants, and even the largest are soon torn to pieces. Those that seek refuge in the twigs are caught and pulled down; spiders, however, sometimes escape by letting themselves hang by a silken thread. Birds follow these forays, darting at the escaping insects, but never eating the ants.

Somewhat like the driver-ants of Africa, these ants have no permanent home. But as a temporary dwelling-place they select some hollow under a $\log$ or in the ground, where great masses cling together like a hanging swar'm of bees. As in a chamber withinj a living nest, in the center of this mass the larvæ and pupæ are kept warm, and cared for 
by their nurses. Tunnel-like entrances to this chamber are kept open, and along these food is carried by those left to work outside.

These ants are said to stand at the head of the tribe in point of intelligence; and few ants show a greater sense of organization and mutual helpfulness.

\section{THE ACKEE}

$\mathrm{O}^{\mathrm{F}}$ all the fruits that would be noticed for beauty alone, the ackee of the tropics excells them all. It is a fruit-flower; that is, its shape and color are such that in itself it is a very pretty' flower as it hangs in the sunshine amid the bright green foliage. Its petals, or fruit-husk, are a bright red, while within depends the creamy lobes, each with a shiny black seed at its tip. This beautiful combination of coloris, together with the shape, makes what we might call a fruit-flower.

So far as eating quality goes, its value is more as a vegetable and lies wholly in the creamy lobes, which, for lack of a better name, we shall . term food-lobes. These lobes are the only parts that can be used for food. The shiny black seeds and the pretty red husks are very poisonous. Indeed, none of it is safe for food until nature herself opens the pods while they still hang on the tree. Should any daring or hungry person assay to use it prematurely, certain death would follow. However, when the pod opens itself it is safe to eat. Only within the past few months the daily paper stated that some children who had cooked their own dinner had used "unfit" ackees, which resulted in the death of one of the children.

Accompanying is a drawing showing a bunch of ackees in different stages of development. The flower proper is insignificant. It is of a yellow-green color and very small and spray-like. To give the best conception of the beauty of this fruit you should see its coloring; which we are unable to reproduce here.

To show you the fruit in detail let us take an open ackee and examine it. On the outside its husk is rough, and it is very thick. You will notice that the husk has three divisions, and that there are three food-lobes. When closed, the lobes lie embedded in the husks, in a place hollowed out for them. Now it would be supposed that each division of husk would hold a single food-lobe, but this is not the arrangement. We shall notice the drawing: 1, a division of the husk; 
2, a food-lobe; 3 , the ebony-black seed. You will notice now the high ridge (4) that separates the compartments (5) where the lobes have lain. It takes half of two different divisions of the husk to form one compartment. This makes it all the more flower-like in appearance. It also

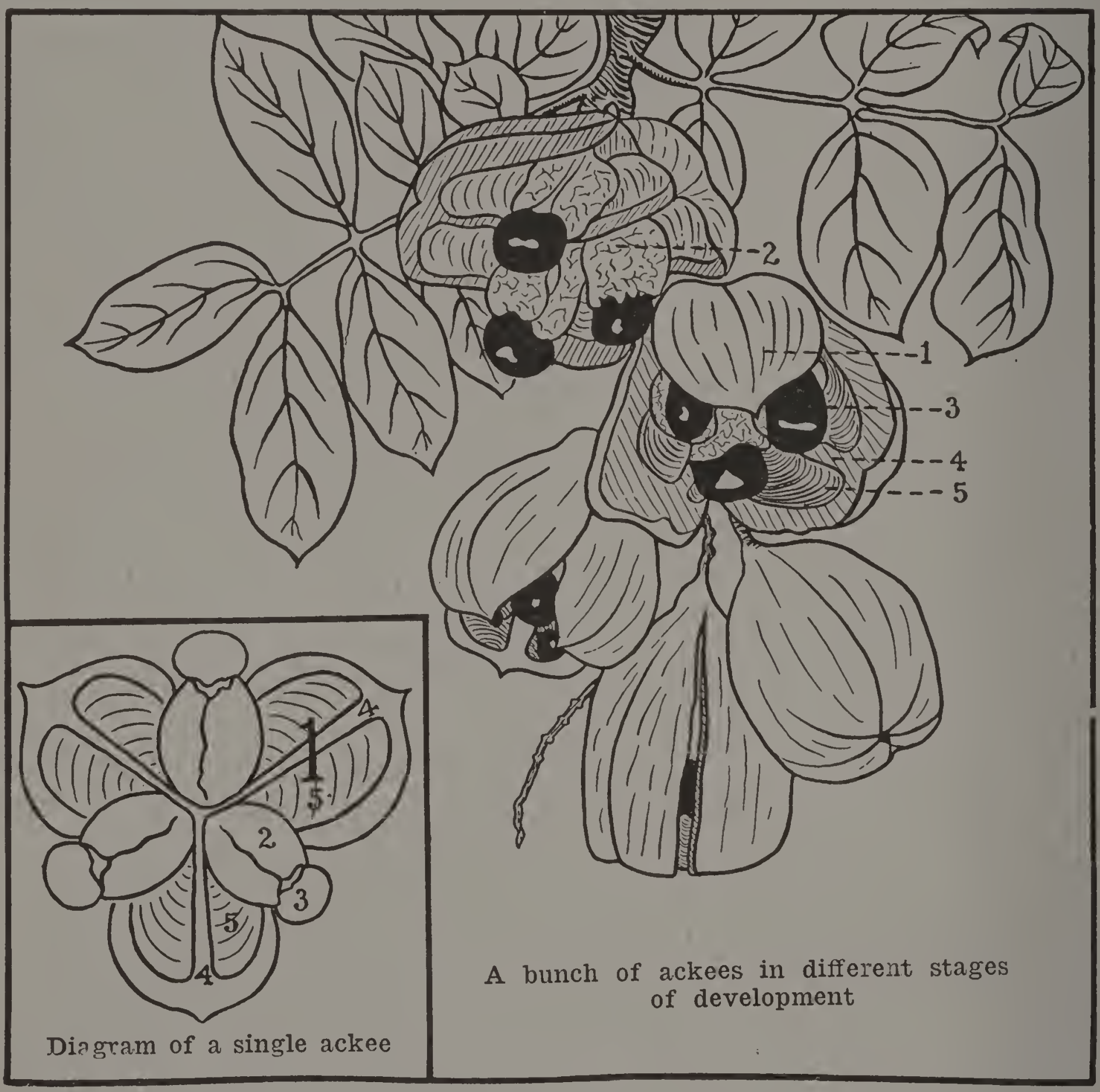

brings the lobes into the air" more quickly, which, no doubt, has something to do with their purification when the pod opens. For it is when the pod opens that the ackee becomes safe to eat.

The food-lobes are of a peculiar flesh-like texture and color. Before being cooked, they must be carefully freed from any little shreds of tile pink lining that still clings to them. The seeds also must be taken away. 
They are then cooked in salted water like any other vegetable and become a very palatable food when served with codfish or even rice. We soon learned to like its strange taste and now relish it as well as the native Jamaicans do.

-Nellie Olson.

\section{MY FIRST EXPERIENCE WITH WINGED ANTS}

$\mathrm{O}$ NE sunshiny afternoon in autumn, as a friend and I were returning from a short trip up one of the slopes of the Alleghany Mountains we observed something that caused us much wonderment. As we looked down into the vale ahead of us, we saw, darting hither and thither, vast numbers of bright wings-almost sparkling, so bright was the sunlight reflected from them. At first we thought they must be gnats, for we liad often noticed swarms of gnats in the air; but we soon saw that they were numerous everywhere, and were not in swarms here and there, as gnats usually are.

As we walked on, still wondering what the insects were and where such a mighty host could have come from, we noticed, near the edge of the road, a clay bank which was cracked open on account of the dry weather and hot sunshine. As we glanced in that direction our attention was arrested by a swarm of insects darting back and forth over the ground, then into the crevice and out again. So numerous were they, and so rapidly were they moving, that the eye seemed almost bewildered.

On closer examination we found this restless throng of insects to be a colony of ants. Some were large, others were small; some had wings, while others did not. As some of the winged ants rose and flew high into the air, the question in our minds was settled. We knew then that the host of insects in the air were ants-ants on the wing.

As this was a new experience, we proceeded homeward with the decision that we would make research concerning the habits of ants to find out what this all meant. But no sooner had we reached home than something else happened that made us wonder. Being rather tired from our walk, we sat down on the steps to rest. Presently a winged ant lighted on one of the steps and came running toward us. My friend brushed it back, and in so doing seemed to injure one of its wings. Then, to our surprize, the ant tore off the bruised wing and ran on for a distance of several feet, where, stopping suddenly, it tore off the other wing and resumed its journey. 
We were astonished at what seemed to us such peculiar behavior of ants and determined to learn something about these interesting little creatures.

\section{PROPAGATION OF FERNS}

"'HERE they are at last!" exclaimed Helen, as she observed the

H large fern in the sitting-room more closely than she had done for several weeks. "I have looked for them many times, and wondered why I could never find them."

"What?" inquired Elsie as she drew nearer to the beautiful green plant, all the more appreciated becanse the out-of-doors was buried beneath the snow.

"Do you see these little brown spots arranged in rows on the underside of the fronds? They are sori and contain spores," replied Helen.

"You mean seeds," spoke up another girl, and at once the interesting way in which ferns propagate was under discussion.

The brown dots were not seeds, neither did they contain seeds, for ferns do not bare seeds. They were collections of spore-cases, and every wee spore-case held many, many tiny spores, each of which, under favorable conditions, was capable of producing a tiny plant; not a fern, however, for ferns do not grow from spores.

All ferns bear spores, but various species have different ways of arranging and protecting their spore-cases. In some species each little group, or sorus, is covered with a thin scale, or shield, while in others the sori are protected by the edges of the fronds turned back or by the contraction of the entire frond.

When the spore-case is ripe, it bursts and scatters the spores broadcast. If you wish to see some of these spores, lay a mature fruiting frond, top side up, on white paper, and allow it to remain in a dry, warm place. The spores will discharge on the paper. A spore falling in a moist, warm place develops into a heart-shaped, green, leaflike body known as the prothallium, which sends forth roots into the ground. Sometimes the prothallium is an inch or more across, but oftener it is less than one fourth that size. It bears on its undersurface two kinds of cells, corresponding to the ovules and pollen-grains of seed-bearing plants. These cells unite, and, as in the case of the union of pollen-grain and ovule among flowering plants, a new plant is the result. But the 
new fern-plant is not wrapped in a seed-case to spend an indefinite time as an embryo plant; it sends up fronds directly from the prothallium and becomes a perennial plant, producing spores each year.

From the vast number of spores produced yearly by one fern it might be expected that ferns would be exceedingly numerous. But, eighteen months are required from the germination of the spore to the appearance of the first leaf. This and the consequent struggle for existence against animal and vegetable enemies account for the fact that ferns are not more numerous.

There are about four thousand species of ferns, ranging in size and habits from those with delicate moss-like leaves to tree-like forms "rising to a height of 35 to 45 feet and crowned by a rosette of leaves 15 to 20 feet long." The vast majority of species live on land, but some are aquatic, even floating; while in the tropics many forms are epiphytic, growing upon other plants, but drawing the needed moisture and food from the air.

Few ferns have commercial value, their chief utility seeming to be that of decoration; though in the early geological ages ferns helped in a large measure to make the great deposits of coal which are so useful in the world today.

- N. Crace Graham.

\section{THE ORANGE-TREE}

THE orange, which we all know so well, is of the same family of 1 fruits as the citron, the lemon, and the lime. There are many different kinds of orange. The manderin oranges of China are small in size, but very fragrant and sweet; so are the tangerines, which are somewhat similar. The Maltese, or blood orange, is grown in southern Italy and derives its name from the deep red color of its pulp.

The original home of the orange seems to have been India, from whence it spread to western Asia, and thence, about the fourteenth century, to Europe. Perhaps it was first introduced into southern Italy and passed on to Spain and Portugal and parts of France where the climate suits it.

An orange-tree covered with fruit is a very beautiful sight, and when it is in bloom is most fragrant. Very often in a large grove there will be trees in bloom, while others are bearing the most luscious fruit ready to be picked. In a twelve-acre grove in the southeastern part of 
Florida there are orange-trees, lemon-trees, grapefruit-trees, the kumquats, or Chinese oranges, and loquots, which resemble our apricot. It is a very beautiful sight to see these hundreds of trees blooming and bearing fruit at the same time.

Orange-trees grow to a great age. They often bear abundant fruit at from fifty to eighty years. Indeed, there are some trees whose age is supposed to be over one hundred years, which still yield a golden crop. When the fruit is meant to be exported to cold climates, it is gathered long before it is ripe, and for that reason the orange never has the same delicious flavor that it has when picked from the tree and eaten.

-Exchange.

\section{BREAD-FRUIT}

THF bread-fruit is a very common product of the West Indies now, 1 though not originally native here. Its importation occurred in this way: Over one hundred years ago King George III of Engand sent a



Bread-fruit ship to the South Sea Islands for a cargo of these young trees, which he desired brought to the British colonies in the West Indies. About three hundred fifty trees were thus transplanted in Jamaica, with the result that now these beautiful trees are to be seen everywhere here.

The trees grow to the height of twenty or thirty feet. The branches are wide-spreading branches and are covered with conspicuously large, shiny, green leaves. As the leaf-buds develop, they look very much like bright-shining candles among the brilliant green foliage, so bright are they. As each bright sheath unfolds, the new leaf appears, and sometimes a flower-bud may be seen within also. It is this flower-bud which finally produces the fruit. If you will look closely at the drawing 
you may see two kinds of flowers-one quite elongated. This soon turns brown and drops off. It is pulpy in texture and may be preserved as a confection. The true flower has a small round head, and from this develops the fruit.

Bread-fruit grows as large sometimes as a child's head. The one from which the sectional drawing was made measured six and one-half by seven and one-half inches. The rind is rough and of a bright green

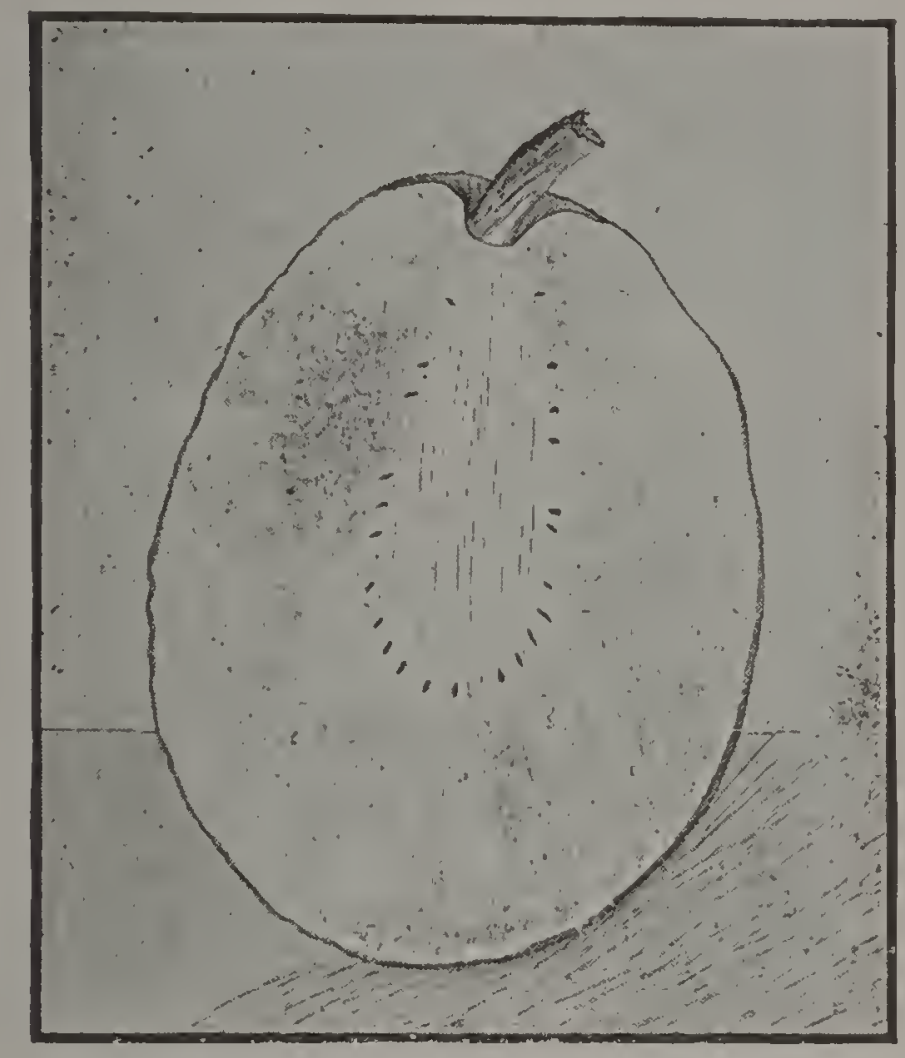

Vertical section of bread-fruit color, but quite thin. Inside is a snowywhite pulp with a core, or heart, in the center. There are two varieties of bread-fruit, one having a white heart and the other a yellow heart. Of the two the "yellow-heart" is the most desirable. This heart may be seen here in the drawing as slightly darker than the surrounding meat; but on being first cut open it was very white. The sticky white juice that exuded from the rind and core (on being cut) soon discolored it. About the heart we see the tiny brown seeds, and radiating out towards the rind the fibrous meat.

As soon as the fruit is fully developed, it is termed "fit", and is cut for immediate use. Should it be left to ripen, it would become sweet and juicy, which is a very undesirable feature in a bread-fruit. When the fruit is picked "fit," the pulp is dry and mealy when cooked, and it is then very much indeed like bread. It may be boiled or roasted. The latter process is the best to bring out the bread-like qualities of the fruit; though when carefully boiled and served immediately, it is found more easily digestible for tender stomachs.

The fruit is roasted by putting it directly upon a bed of hot coals and turning it from time to time to form an even brown crust of the rind. This is then trimmed off. the "bread" opened for the removal of the heart, which is not desirable, and the remainder sliced for immediate serving. Butter and salt add to the deliciousness. It is indeed a wonderful substitute for that article of food. And thus we see how God 
meets the needs of his creatures in every land. Speaking personally, we are very fond indeed of the bread-fruit, and are very thankful that it is obtainable at nearly all seasons of the year. -Nellie Olson.

\section{THE BEECH-TREE IN WINTER}

T the winter, trees, bare as they look, have a peculiar beauty that, by a 1 little study, reveals facts and peculiarities that we can not see during any other season.

Fach family of trees has definite characteristics of its own which distinguish it from any other family. It is a few of these traits that we will consider now.

By observing the peculiarities of the different kinds of trees we are able to distinguish one kind from another at a distance, by the shape, the branches, the bark, and the many other details that go to make up a tree.

Few well-known trees are more beautiful in shape and the nature of their branches than the beech. When you once familiarize yourself with its peculiarities, you will always recognize it, even at a distance.

When it grows in a thick wood, it has very few branches of importance except at the top; but when it grows in the open, its branches spread out in a very beautiful way. Another fact is that when it grows in a thicket, its roots spread out from the base of the trunk and do not root deep-in the earth; while when it grows alone, it sends its roots downward.

The average height of a well-developed beech is from sixty to one liundred feet. Its branches and twigs are smooth and slender. Its bark is clean and close-fitting, a reddish brown on twig's and branches and a prominent gray on the main trunk.

The wood is hard, very close-grained, and not easy to split. It is valuable in the manufacture of tool-handles, shoe-lasts, and chairs.

The fruit of the tree, called the beech-nut, is enclosed in a prickly bur, containing one or two (rarely three) triangular-shaped nuts. The nuts are palatable and nutritious. They not uncommonly hang on the tree till very cold weather. Squirrels consider them among' their delicacies and sometimes store large quantities of them in hollow trees.

The beech is common in the eastern and central portions of the United States and is said to grow as far north as Nova Scotia. 
In autumn the beech is among the most beautiful of trees. When the leaves are turning to their different colors, they have graced many

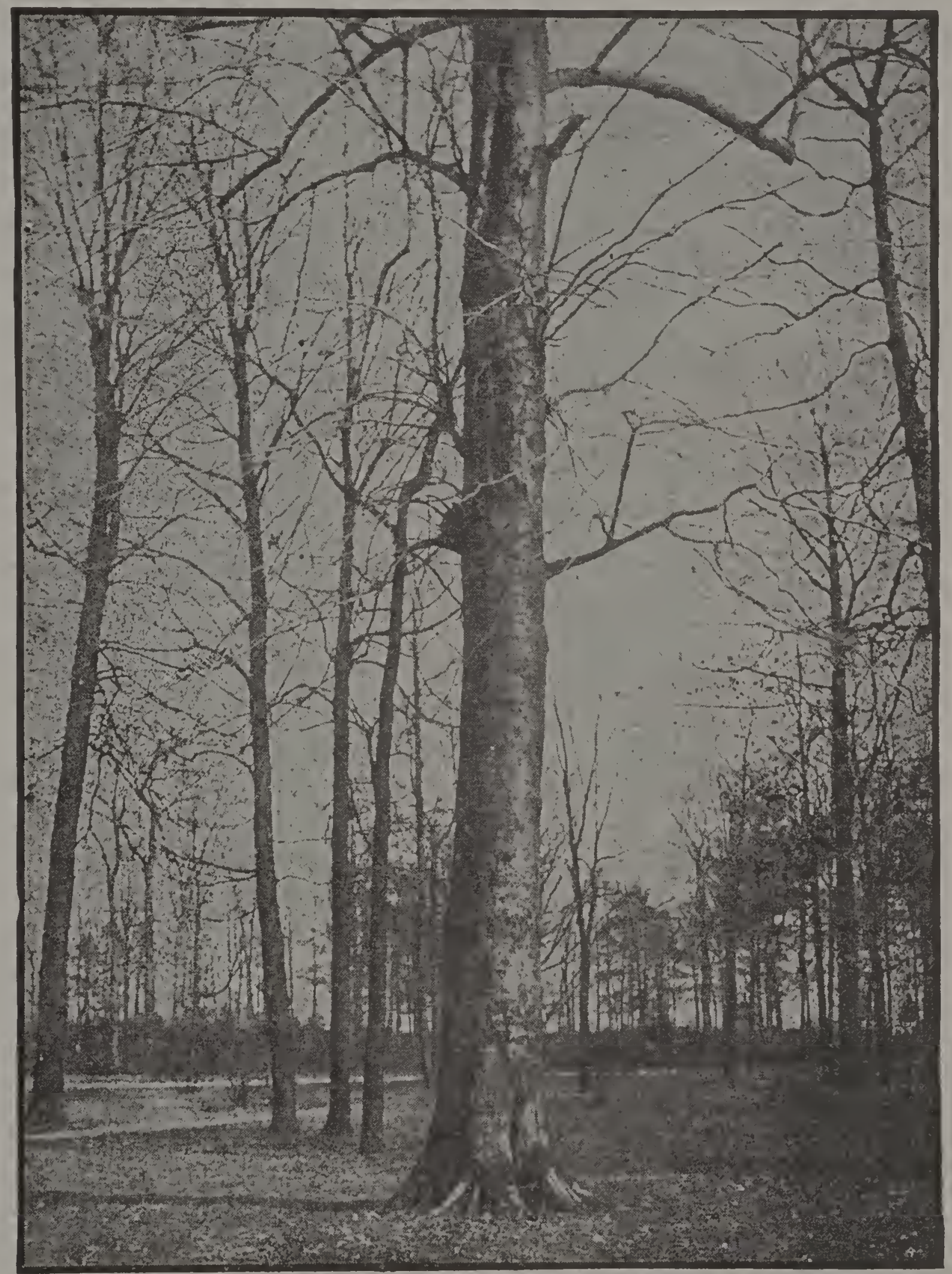

a canvas painted by some of the best artists of the world. Poets and writers have pictured its beauty for centuries.

By more closely observing trees and being able to distinguish the different kinds, we not only can get more enjoyment out of trips through 
the woods, but also can more, readily detect the beautiful handiwork of nature, the author and preserver of which is God.

\section{THE NIGHT-BLOOMING CEREUS}

$\mathbf{I}^{\mathrm{T}}$ was almost bedtime when Gertrude came rushing in and asked me $\mathbf{I}$ to accompany her to the home of one of the neighbors. Upon my asking why she wished to go, she told me that this lady had a rare and peculiar plant which did not bloom until it had reached a great age, and then only at night, that on this night it was blooming, and that we were invited to see it. I threw a light wrap around me and went with her.

When we reached the neighbor's home, we found a number of people assembled to watch the opening of the wonderful flowers. In the corner of the veranda stood the tall, graceful plant, with its large flowerbuds slowly expanding, while its fragrant perfume pervaded the whole place.

The lady told me that the plant was a night-blooming cereus, and that she had gotten it when it was about one year old, sixteen years ago. It began blooming when seven years old, and had bloomed every summer since that time.

A bud when ready to bloom begins to open in the evening, and after a few hour's a full-blown flower-a beautiful white wax-like blossomis seen. But it is destined to a short existence; by sunrise next day it will be withered.

This plant had always bloomed only once during the year, and usually that was during August. But last summer it had three seasons of blooming, the first one being in the spring. One cool night the flowers did not open until midnight or later, and they lasted until after sunrise. This afforded a good opportunity to photograph the plant in full bloom, which was done.

The night-blooming cereus belongs to the great cactus family. There are many species of the Cereus genus. The stems may be short or elongated, creeping or erect. The Cereus giganteus, or the giant cactus, sometimes attains a height of 60 feet and a diameter of 2 feet. There are several species that bloom at night, and they get their name from this habit.

The peculiarities of the cactus family are due to its adaptation to perennial drouth conditions. Plants growing in well-moistened regions 


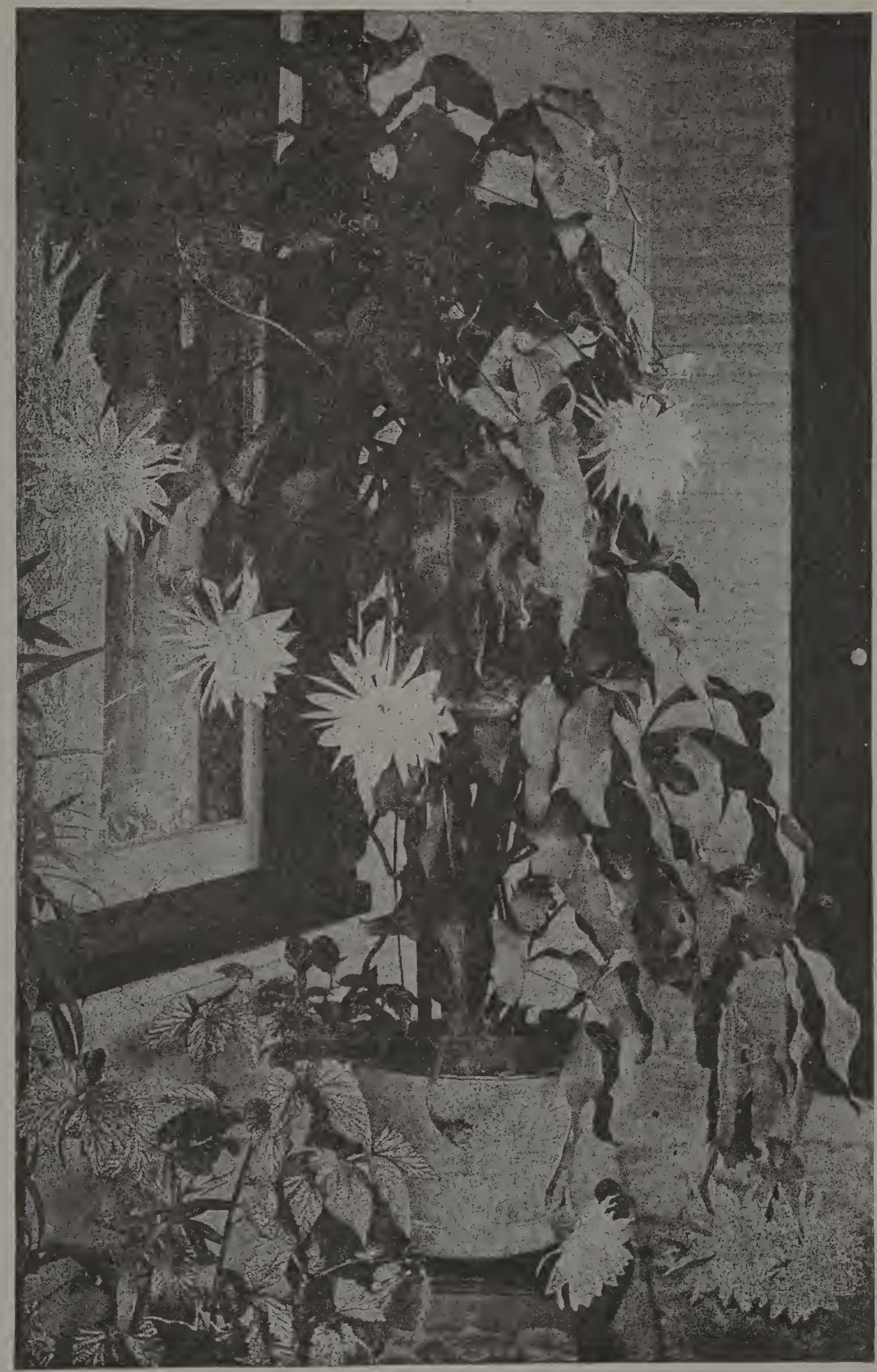


spread their leaves out and expose a large area to the air and sunshine, and the amount of moisture given off thereby can be replaced by that taken in at the roots. But in order to survive in arid regions the cactus must be adjusted to its environment. It must be so constructed as to prevent any unnecessary loss of water contained in its tissues and to retain all the scanty supply which reaches them. The body of the plant contains a large amount of water-storage tissue which retains water with great tenacity. The amount of surface exposure is small and in most species the leaves have become reduced to mere spines and prickles, while the stems have become fleshy, sometimes resembling leaves in shape. The flowers are often brilliantly colored, and the fruit of some species is edible.

\section{HOW I CAUGHT A BUTTERFLY}

NE day in the early autumn the postman left at my door a small square wooden box. The cover was thickly perforated with small holes. This suggested that on the inside was some manner of life which required air to breathe. I opened the box and poured the contents out upon the table. And lo! a bright-colored, wriggling, twisting worm greeted my sight.

It was about four inches in length and about three inches in circumference. It had more than eight pairs of legs. This left no doubt as to its correct classification. We quickly assigned it to its proper name, "Caterpillar."

This we knew was his first age of existence after leaving the egg. In that state it is called the larva.

I had been expecting and even anxiously looking for the coming of this interesting little visitor. Also, I knew about its voracious' appetite, and so had prepared the most tempting dinner he could even wish for. Upon his table there were placed little heaps of mulberry-leaves and oak-leaves, and the leaves of the poplar, elm, thorn, and castor-oil bean.

Presently, he lifted his head from side to side as though contemplating the luscious dimmer that was spread out before him. But this was only make-believe, as this particular species of caterpillar is wholly blind. He nimbled about quite lively until he came across the mulberryleaves. These he greedily devoured until there was nothing left but a mass of stems and midveins. He stripped the pulpy mass from the 
woody structure as regularly and completely as you could do it with your scissors. Perhaps he knew this was to be his last dinner during his worm life, so he ate and ate as though he could not get enough, for he needed to lay up in store sufficient for a long, long nap.

Soon after his meal he commenced a tour of investigation in his apartments. He traveled rapidly from corner to corner and from floor to ceiling as though dissatisfied with his lodgings.

We finally carried him out and placed him upon a slender twig of a tree. Almost immediately he stretched himself out at full length and settled himiself as though for a period of rest.

After a little time of quiet, he moved his head to the foot of his resting-place, and with' his mouth he fastened the end of a fine, shimmering thread of jelly as for a firm footing. Then straightening his body he carried the glistening, silvery thread, which hardened as it came in contact with the air, and fastened it to a point just beyond his head.

In this manner he worked diligently, carrying the silvery thread back and forth and fastening it at both ends until he had completely surrounded his entire body in a silken sheath. Then he formed another inside layer' in the same manner, and still another until his little house was sufficiently strong and firm to protect it against both wind and weather.

At a certain stage of his building I took the scissol's and made a small round incision through his sheath. He turned quickly as though impatient at the intrusion and then began patching up the hole. Back and forth, back and forth he fastened the tiny threads on the edges until the fracture was completely mended and his house strong and secure again.

A tube carrying this fine jelly, thread-like substance extends through the entire length of his body and issues forth from two small canals on the upper lip.

I finally cut the twig and placed it in my bureau-drawer to await further development. It remained there during the entire winter. A slight pressure at any time upon the sheath would create an agitation within which indicated that life in some form still remained.

This sleeping condition was the second stage of its existence and is called the chrysalid stage.

As the warm days of spring approached, I made frequent visits to 
the snug little cradle of my patient little sleeper. I knew that he would soon wake up and that then he would gnaw his way out of his nest and perhaps in time to catcly a glimpse of the early May flowers before his brief existence would close forever.

One morning early in May I found his little nest burst open at one end. And lo! instead of the wriggling, twisting, green, and hideouslooking worm that shut himself up so carefully in the early fall, I beheld a large, gorgeously-colored, broad-winged butterfly fluttering about its cradle as if anxious to behold something of the beautiful outside world.

And so I finally caught my butterfly. I carefully lifted the longcoveted treasure and rested it upon my hand for a while to examine its wondrous beauty. With its wings spread out, it measured fully six inches across the back. It was a perfect creature-perfect in its insect life, the third and last age of its existence. With thrilling interest I gazed upon it, so resplendent in coloring and so beautiful in form and appearance-a symbol of the resurrection, I thought.

First, the creeping, crawling worm, fettered and bound by all the conditions of its earthly life; second, the time of resting in its narrow prison-house; third, its radiant blossoming forth from its long winter sleep into the beauty and perfection of its new creation.

Instinctively, with my little captive still fluttering upon the palm of my hand, I went to a window and held it unfettered far out toward the open field. For an instant it wavered and settled back in my hand; then as if caught by the inspiration of the thought and by the impulse to fulfil its mission, it spread its wing and soared away upon the breeze.

- Sara E. Farman.

\section{A PLANT THAT COUGHS}

ONE of the strangest plants that grows is the coughing-plant, which is found in the Sahara Desert in Africa. Traveler's tell us that this plant makes a noise exactly like the cough of a human being. This peculiar noise is caused by dust choking up the pores of the plant. This makes a powerful gas accumulate inside the plant. When the gas has gained sufficient pressure, it explodes with a peculiar cough-like noise, and thus it gets rid of the offending dust.

- Selected. 



LIBRARY OF CONGRESS MFinty

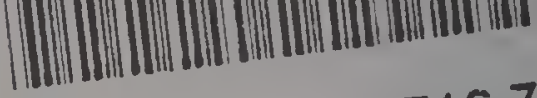
00050487167 